\title{
GRAY MASS
}

\section{A CRitical Engagement With John Gray's Political Philosophy and the Role of}

\author{
ChRISTIAN Eschatology
}

\author{
By \\ Benjamin David Arcus
}

\begin{abstract}
A thesis
submitted to the Victoria University of Wellington in fulfillment of the requirements for the degree of Master of Arts in Religious Studies
\end{abstract}

Victoria University of Wellington 2012 


\section{ABSTRACT}

Contemporary political philosopher John Gray has recently asserted: "modern politics is a chapter in the history of religion." Gray demonstrates how the roots of modern political violence can be traced back to Christianity. Furthermore, he sees Utopianism, "the Enlightenment project", anthropocentrism and any notion of human meaning as all originating in the Christian notion of "salvation". Gray argues that all of these ideas are disproven by values pluralism - the idea that human life consists of an incommensurable range of values. Gray is also critical of human beings technological appropriation of the world and the ecological crisis that this consciousness has precipitated. Gray claims that all forms of universalism are mistaken because they privilege a particular set of values at the expense of others. Gray offers a modus vivendi as a political construct that can appropriate the insights of values pluralism, without privileging any particular set of values. Despite considering Christianity (and its offspring) illusory, Gray asserts that the "myth of human meaning" is a "necessary illusion"; it is one that human beings cannot live without. Gray's argument, however, is beset with inconsistencies, including an implicit teleology, despite his explicit rejection of all teleology, and the tendency of his thought toward nihilism, undermining his proposal of a modus vivendi. In his own constructive proposal Gray inadvertently privileges values of peaceful coexistence and human flourishing. His own political vision has some similarities with the Christian vision of the ideal human life. Christian eschatology is examined through the work of Jürgen Moltmann, and the values of hope and love are highlighted as the ethical consequence of Christian eschatology, as opposed to the violence that Gray claims has been generated from it. Moltmann's thought also reveals the resources present in a theological perspective that are able to resolve some of the contradictions between individuality and sociality and between human beings and nature. This has significant implications for the ecological crisis, which is also one of Gray's central concerns. Finally, Martin Heidegger's concept of Gelassenheit is examined as a point of common ground between Gray's thought and a theological approach to the world of politics and nature. 


\section{CONTENTS}

$\begin{array}{ll}\text { Abstract } & 1\end{array}$

1. Introduction 4

2. A History of Violence 26

$\begin{array}{ll}\text { The Futility OF 'UtOPIAN’ Politics } & 27\end{array}$

The Christian Roots of Anthropocentrism, Utopian Thinking and Modern

POLITICAL VIOLENCE

$\begin{array}{ll}\text { MOdUS VIVENDI } & 61\end{array}$

3. Gray's Anatomy 67

AN IMmanent CRITIQUe OF GRAY'S TheSIS $\quad 70$

$\begin{array}{ll}\text { GRAY'S FAITH } & 83\end{array}$

$\begin{array}{ll}\text { ChRISTIANITY AND VIOLENCE } & 91\end{array}$

4. Hope Remains 102

$\begin{array}{ll}\text { MOLTMANN'S TRINITARIAN ONTOLOGY } & 105\end{array}$

Moltmann's Eschatology: God Will Be All in All 111

$\begin{array}{ll}\text { The Politics of Eschatology } & 124\end{array}$

$\begin{array}{ll}\text { 5. Conclusions } & 130\end{array}$

$\begin{array}{ll}\text { Bibliography } & 143\end{array}$ 


\title{
CHAPTER 1: INTRODUCTION
}

\author{
AN INTRODUCTION TO JOHN GRAY'S THOUGHT
}

John Gray is a political philosopher who has come to popular attention in recent times through his book Straw Dogs: Thoughts on Humans and Other Animals. ${ }^{1}$ This book has drawn an original (if somewhat pessimistic) picture of human life, suggesting that human beings are of no more value than the other creatures that inhabit our planet. Our hubris in assuming we have a special destiny or telos in history is an error that can only end in either an ecological or sociological adjustment to the size of the unsustainable human population. The title draws its name from the straw animals used in ancient Chinese rituals, which were revered for the duration of the ritual and afterwards "trampled on and tossed aside." It is this image that Gray thinks most aptly captures the (lack of) meaning of human life. More recently, in his Black Mass: Apocalyptic Religion and the Death of Utopia, ${ }^{3}$ Gray has argued that the rise of what he calls "apocalyptic violence" - such as the conflicts in Iraq and Afghanistan - can be directly attributed to "utopian thinking". Such thinking is itself a direct descendant of Christianity and a secularized version of Christian hopes for salvation and faith in a human telos or destiny. While this idea is not wholly original, Gray makes a compelling analysis of current world politics, attributing the major international conflicts in Iraq and Afghanistan to a misplaced faith in progress,

\footnotetext{
1 John Gray, Straw Dogs: Thoughts On Humans and Other Animals (London: Granta Books, 2002).

2 Ibid., 33-4.

3 John Gray, Black Mass: Apocalyptic Religion and the Death of Utopia (London: Allen Lane, 2007).
} 
which he conceives of as a secular manifestation of repressed religious hopes. Also notable is Gray's prediction of the recent international economic crisis, in his prescient False Dawn: The Delusions of Global Capitalism. ${ }^{4}$

Gray departs from traditional Liberalism, and in particular responds to the Liberalism of J.S. Mill, arguing that "disabling incommensurabilities" hamstring his argument in On Liberty. ${ }^{5}$ He argues that Liberalism is unsustainable in light of values pluralism. For Gray, the difficulties presented by incommensurable values "plague[s] later liberal thinkers such as Isaiah Berlin and Joseph Raz who have sought to ground liberalism in a value-pluralist ethical theory," and he maintains that "no thinker in Mill's liberal posterity has been able to demonstrate the universal authority of liberal ideals." In his later work, Gray takes his critique even further, arguing that all forms of universal values are illusory and that there can be no rational construction of moral and ethical life. It is here that he draws on pessimistic philosophers such as Schopenhauer and Nietzsche, coming to similar conclusions about the ultimate meaninglessness of human existence.

Gray's contribution to the critique of universal politics is in his identification of Christian faith as the source of modern notions of progress and human destiny. Drawing on Norman Cohn, Gray demonstrates the Christian foundations of our

\footnotetext{
${ }^{4}$ John Gray, False Dawn: The Delusions of Global Capitalism (London: Granta Books, 1998).

5 John Gray, "Mill's Liberalism and Liberalism's Posterity," The Journal of Ethics 4, no. 1/2 (March 2000): 137-165.

6 Ibid., 137.

${ }^{7}$ Ibid.
} 
humanistic belief in political or technological salvation. Gray proposes that, while religion is an illusion, it is a necessary illusion that human beings cannot live without. Like sexual desire, repressed religious faith in human destiny re-emerges in altered forms. However, the destiny that Gray predicts for humanity is either one of extinction or at least a radical reduction of our population through a catastrophe of either ecological or political origins, as human consumption and instrumentalism toward nature makes scarcity of resources the most pressing issue for future politics.

\section{BACKGROUND}

Born into a British, working-class family, Gray's first academic appointment was in 1976 as a Fellow and tutor at Jesus College, Oxford University. He remained there for 21 years, eventually becoming Professor of Politics. He has served as a visiting professor at a number of American academic institutions (including Harvard University from 1985-6) and was Professor of European Thought at the London School of Economics and Political Science until his retirement from academic life in early 2008. As a regular columnist for The New Statesman and The Guardian, Gray has been an influential social and political commentator in Britain. ${ }^{8}$ Including Straw Dogs and Black Mass, Gray has authored fourteen books and co-authored numerous others in the area of Liberalism, values and modern politics. Described by

\footnotetext{
8 W. Self, "John Gray: Forget Everything You Know," The Independent (London), 3 September 2002; available from http://www.independent.co.uk/news/people/profiles/john-gray-forget-everything-you-know-64187 8.html; Internet.
} 
one commentator as "the most important living philosopher" ${ }^{9}$ Gray has had a significant impact on modern political discourse and in recent years has attracted a popular following through his more accessible books.

\section{VAlUes PluRAlism as the END of UNIVERSALISM}

One of Gray's central arguments is that Liberalism, of the sort that seeks to apply liberal values universally, is no longer viable in a world of plural values. Gray targets those who think that current Western-style democracy, and in particular American capitalist democracy, is an ideal form of government which should (and some believe will) be adopted universally. Gray's early work critiques the idea of a universal liberal system and demonstrates that, due to the existence of 'incommensurable values', there can be no universal system of any kind which captures the ideal human society and which should be (or could be successfully) implemented ubiquitously. In Post Liberalism Gray concludes: “...there are many, diverse and incompatible, forms of life in which human well-being may be realized. We can recognize as genuine forms of human flourishing a whole variety of forms of life, while at the same time recognizing that none of them is the best form towards which all others approximate."10 Gray takes exception to Francis Fukuyama's claim that "history, conceived as the history of conflict between rival ideologies and systems of institutions, is over, and liberal democracy has been revealed as the final

\footnotetext{
9 Will Self, Taken from the back cover of Black Mass.

10 John Gray, Post Liberalism: Studies in Political Thought (New York: Routledge, 1993), 66.
} 
form of human government."11 There is no ideal political system in Gray's thought, since there is no ideal way of life for humanity.

Gray's understanding of "values pluralism" lies at the core of his critique of Liberalism. In particular the notion of "incommensurable values" undermines the ideal of universal liberal politics, which animates much of liberal theorizing. "Some varieties of the good life are neither better nor worse than each other, nor the same in value, but incommensurable," writes Gray; "they are differently valuable." ${ }^{12}$ It is the fact that there are plural values, many of which cannot be compared or combined in rational ways, which dooms the project of rationally constructing a liberal regime that is universally authoritative. Plural values, and more specifically the incommensurability of these values, means that no one value or system of values may rationally be privileged over others. Not even the attempt to safeguard a minimum of liberal values through the legislation of rights can be maintained in light of the incommensurability of values. Gray observes: "From Locke and Kant to Rawls and Hayek, a line of liberal thinkers have accepted that the goods of life clash, with no settlement of their claims being without loss; but they have sought to state principles of right and justice that stand aloof from these conflicts. If, however, the claims of justice embody values that are themselves incompatible and incommensurable, that version of the liberal project runs aground." ${ }^{13}$ Gray refers in particular to the rights discourse prevalent in American politics, which creates

\footnotetext{
11 Ibid., 202. Gray refers to Fukuyama, Francis "The End of History?", in The National Interest, no.16, (Summer, 1989), 3-18.

12 John Gray, Two Faces of Liberalism (New York: New Press, 2000), 34.

13 Ibid.
} 
intractable conflicts out of issues such as the abortion debate; issues he believes could best be resolved through political negotiation. ${ }^{14}$

Gray draws heavily on the work of Isaiah Berlin for his understanding of incommensurable values and quotes him at length. ${ }^{15}$ The incommensurability of values refers to three types of conflict between and within values. The first is the competing claims that many values make, which cannot be reasonably (i.e. through use of reason) resolved. Gray uses an example that is worth quoting at length, in order to illustrate this idea:

Say I have an understanding with a close friend to be on hand when she is in serious trouble; but in the circumstances this is an understanding that I can honour only by defaulting on a contractual engagement I have made to a business enterprise. What should I do? There is no answer that is right for every person or every circumstance; but what I do may still be right or wrong.

I may try to assess the impact of the interests of my friend and the business of failing to honour each engagement. Further, I may consider how defaulting on each of them meshes with my goals. How significant a role do I expect my friend and my business relationships to play in the life I aim to lead? These considerations may tell in favour of one course of action. My decision in cases such as this need not be arbitrary or groundless, an acte gratuite for which no reason can be given. Nor need it be the expression of a sheer preference. Given the context of my history and my circumstances, my choice may be right or wrong. ${ }^{16}$

\footnotetext{
14 John Gray, Enlightenment's Wake: Politics and Culture at the Close of the Modern Age (New York: Routledge, 1995), 7-11.

15 E.g. in Black Mass, 277-8; "Berlin's Agonistic Liberalism" in Post Liberalism; Enlightenment's Wake, 81, 86; Two Faces of Liberalism, 30-1, 39-40, 82, 95.

16 Ibid., 42-3.
} 
There are times when loyalty and honour may come into conflict in a way in which there is no reasonable means to resolve the conflict without loss. These values can be said to be incommensurable since conflicts between them cannot be reasonably resolved, or even compared on a scale - they are of incomparable value.

The second form of incommensurable values is that found within the application of a particular value; when justice, for example can be applied in various ways in a situation, where two or more options are no better or worse than each other, and where each option involves a measure of loss. In such situations, there are no rational ways of resolving such conflicts. Gray again gives illustrative examples of both kinds:

[J]ust as there are conflicts among ultimate values that are incommensurable - between liberty and equality, equality and general welfare, say - so there are conflicts no less radical within liberty itself - conflicts among distinct liberties having incommensurable value. When the liberty of privacy competes with freedom of information, a trade-off must be made and a balance struck; but there is no comprehensive theory - no theory of the sort John Stuart Mill thought he possessed when he sought to found the 'one very simple principle' of On Liberty in the requirements of general utility - by which such conflicts among liberties might be arbitrated. ${ }^{17}$

The third way in which values can be described as incommensurable is when different cultures have different ways of life, embodying different values. These ways of life are based on differing conceptions of 'the good' in human life, and often cannot be reasonably compared, since they each represent a form of human

17 Gray, Post Liberalism, 66. 
flourishing which may be no better or no worse than any other. Gray writes: "Cultures differ not only in how they interpret virtues they have in common but in the virtues they recognize. What some praise as virtuous others may condemn as a vice. When cultures honour different virtues, it is sometimes impossible to compare the value of the ways of life in which they are embodied." ${ }^{\text {"18 }}$ There is incommensurability even between different systems of value. The values of honour, wisdom and courage prized by Greek culture, for example, cannot be regarded as either better or worse than Christian values of love and mercy; they are incommensurable.

Gray distinguishes the idea of "value pluralism" from relativism. The idea of relativism is dependent on a common way of life with shared ideas of ethics. ${ }^{19}$ There, the conflicts arise from preferences and wants that conflict on a subjective level. In relativism personal preference is the final authority in ethics - personal preference being a shared value, a universally accepted good. However, this is really again reducing ethical life to only one form of life. In fact, Gray argues, there are many ways of life, which base their choices and decisions on values which they hold to be objectively of value, and it is these ways of life and the incommensurability of their values, rather than just the personal preferences of those who hold the value of relativist truth, which creates the kinds of conflicts which cannot be resolved fairly by any universally accepted, rational system of values. "The claim that values-pluralism is a species of relativism," writes Gray, "depends on a radically holistic view of

\footnotetext{
18 Gray, Two Faces of Liberalism, 35.

19 Ibid., 52-55.
} 
ethical life. That view is false to common experience." ${ }^{20}$ Relativism is dependent on a culture that values it above other forms of truth.

The consequence of incommensurable values is that there is no universal system of values that can be appealed to in order to resolve many types of conflict. For Gray, this undermines the form of liberal theorizing which aims to find "a rational consensus on the best way of life." 21 Incommensurable values signal the futility of a search for a rationally constructed, universal regime and thus falsify much of what can be called the liberal project over the last few hundred years. As demonstrated above, the upholding of (usually liberal) values in law through rights-based legislation is also doomed to failure, since rights are only the individualising of certain values. These "rights" make claims that are as incommensurable as the values they are derived from. The truth of incommensurable values "has large consequences" writes Gray. "It means that there can be no such thing as an ideally liberal regime. Because rights make conflicting demands that can be reasonably resolved in different ways, the very idea of such a regime is a mistake."22

Gray challenges the overarching philosophical construction of "the good life" in its universalizable forms. Incommensurable values demonstrate the falsity of such a project. In his view, philosophers "from Aristotle up to the present" 23 have believed that the virtues (what is regarded as the good in human life) work together to form a

\footnotetext{
20 Ibid., 54.

21 Ibid., 1.

22 Ibid., 15.

23 Ibid., 38.
} 
consistent whole, and it is this idea which is the foundation for any belief in a universal regime which can best sustain ideal human society. However, Gray believes this foundational idea to be a fiction. He writes: "If rational inquiry has failed to produce agreement on the best life, it is not because of any imperfection in human reason. It is because the idea of perfection has no sense in human life." ${ }^{24}$ For Gray, there is no ideal human good; rather there are many goods, and many equally valid ways for human life to be expressed.

Gray attributes the source of this error in philosophy to that form of rationalism which considers the idea of 'the good' to be a rationally apprehensible ideal. However, Gray argues that the attempt to apply our rational categories to society is a mistake. Gray draws on the thinking of F.C. Hayek on this point, which Gray describes as 'Kantian':

In its most fundamental aspect, Hayek's thought is Kantian in its denial of our capacity to know things as they are or the world as it is. It is in his denial that we can know things as they are, and in his insistence that the order we find in our experiences, including even our sensory experiences, is the product of the creative activity of our minds rather than a reality given to us by the world, that Hayek's Kantianism consists. ${ }^{25}$

Elsewhere Gray argues that Hayek "identifies a limit to the powers of reason more severe than any Kant could have admitted ...our own minds, no less than the external world, must in the end remain a domain of mystery for us, being governed

\footnotetext{
24 Ibid., 39.

25 John Gray, Hayek On Liberty (Oxford: Basil Blackwell Publishers, 1984), 4-5.
} 
by rules whose content we cannot discover." ${ }^{26}$ This belief animates the core of Gray's critique on Liberal values and his consequent attack on the Enlightenment "faith" in progress and, indeed, on any utopian thinking which asserts that the creation of a perfect human world is possible. In his assessment of Hayek's thought, Gray concludes that:

The dominant superstition of the Age of Reason is the belief that vital social institutions - the law, language, and morality, as well as the market - must be or can become products of conscious contrivance and control, if they are effectively to serve human purposes. This modern superstition results from an anthropomorphic transposition of mentalist categories to the life of society. ${ }^{27}$

Gray traces this anthropocentric error in philosophy - the assumption that the rational categories that we use to describe reality are an accurate reflection of it back to writing, which he believes gave humanity the ability to "invent a world of abstract entities and mistake them for reality." ${ }^{\prime 28}$ This was the start of humanity separating itself from the natural world, and "an error of thinking" ${ }^{29}$ which created a whole history of thought, beginning with Plato's abstractions of the Good, the Beautiful and the True. It is this legacy of abstract thought that Gray believes to be both a mistake in our thinking and the source of Western civilization's history of war, tyranny and violence, since much of this history has sprung from humanity's desire to pursue, uphold or enforce these abstract ideals.

\footnotetext{
26 Gray, Post Liberalism, 34.

27 Ibid., 36.

28 Gray, Straw Dogs, 56.

29 Ibid., 58.
} 


\section{THE ANTHROPOMORPHIC ERROR AND ITS CHRISTIAN ROOTS}

"The anthropomorphic error" is another central theme in Gray's thought, and one that Gray critiques most vigorously in Straw Dogs. Not only do we make rational errors in assuming that the external world corresponds to our rational categories of thought, we also assume that human life has some kind of meaning or "destiny". For Gray, it is this anthropomorphism that (mistakenly) provides the foundation for the belief in "progress". This is the central creed of secular humanism - that humanity is the final arbiter of meaning and truth in the world. We promote our humanist worldviews in opposition to the truth that we are value-less, or at least, of no more value than the other creatures of this planet. Gray believes that "human life has no more meaning than the life of slime mould." 30 The belief that humans have a privileged position in the world is a mistake and most of humanistic philosophy has been built upon that unchallenged assumption. Gray aligns himself with philosopher Arthur Schopenhauer, whom he considers to have held the same view that forms the basis for all of Gray's thought: "that the free, conscious individual who is at the core of Christianity and Humanism is an error that conceals from us what we really are."31 And what we are, in Gray's opinion, is "embodiments of universal Will, the struggling, suffering energy that animates everything in the world." 32

Gray traces the roots of anthropocentrism and thus of humanism back to

\footnotetext{
30 Ibid., 33.

31 Ibid., 41.

32 Ibid.
} 
Christianity. "Christianity's cardinal error" ${ }^{33}$ stems from the doctrine that human beings are made in the image of God. It is this idea that Gray believes has founded anthropocentric thought:

In Christian theism, value is an emanation of personality, human or divine; human beings have infinite worth because they partake of the divine personality that created them; and a world without personality, if such there could be, could not but be worthless. Denuded of its theistic framework and content, the idea of the human species as the source of value in the world, and of human relations with nature being instrumental ones in which human activities alone are value-creating, emerges in modern times as secular humanism, which from the Renaissance onwards is a defining element in the modern world-view. ${ }^{34}$

Without a theistic foundation, however, anthropocentrism is no longer rationally defensible. The special place afforded human beings in history by secular humanism is only the re-emergence of repressed religious desires desires that are ubiquitous and irreducibly human.

\section{THE NECESSITY OF RELIGION}

In Black Mass, Gray insists that Religion is inescapable, given that "religion answer[s] to universal human needs." ${ }^{35}$ While Gray believes that religions are not literally true, he argues that "they are myths that preserve in symbolic or metaphorical form truths that might otherwise be lost, and the mass of humankind will never be able to do without them." ${ }^{36}$ Exactly what these beliefs are, Gray does

\footnotetext{
33 Ibid., 37.

34 Gray, Enlightenment's Wake, 158.

35 Gray, Black Mass, 267.

36 Ibid., 263-4.
} 
not elaborate on, but he insists that the desire for secularization - the removal of religion from society - "is a kind of contradiction, for it is defined by what it excludes. Post-Christian secular societies are formed by the beliefs they reject, whereas a society that had truly left Christianity behind would lack the concepts that shaped secular thought." 37 Gray argues that religion cannot be suppressed and that where it is attempted, it re-emerges in other forms. This idea is the foundation of his argument that the Christian belief in salvation is the source of utopian politics. When the millennial belief in salvation was repressed, it re-emerged in secular politics as utopian thinking; the religious belief in the salvation of humanity reappeared in secular form. Gray writes: "Like repressed sexual desire, faith returns, often in grotesque forms, to govern the lives of those who deny it." 38 Religion is an illusion, but it is an illusion that Gray thinks humanity cannot do without.

\section{'PROgRESS' AS RePRESSED RELIGION}

Gray extends his critique of Liberalism and the notion of a universal human ideal to the Enlightenment belief in "progress"; a belief that Gray also argues is founded in religion. Gray thinks the "faith" (as he calls it) in the idea that human history is steadily moving toward a universal human culture, is an error. He believes it to be a belief that has more to do with repressed religious longings than with any rational conception of history. The belief in a perfect human society is merely a secularised form of the Christian belief in salvation - a new heaven and earth where

\footnotetext{
37 Ibid., 268.

38 Ibid., 269.
} 
human life is saved from all of its imperfections. In Heresies: Against Progress and Other Illusions, Gray writes:

The thinkers of the Enlightenment saw themselves as reviving paganism, but they lacked the pagan sense of the dangers of hubris. With few exceptions, these savants were actually neo-Christians, missionaries of a new gospel more fantastical than anything in the creed they imagined they had abandoned. Their belief in progress was only the Christian doctrine of providence emptied of transcendence and mystery.

Secular societies are ruled by repressed religion. Screened off from conscious awareness, the religious impulse has mutated, returning as the fantasy of salvation through politics, or - now that faith in politics is decidedly shaky - through a cult of science and technology. ${ }^{39}$

Gray maintains this critique of progress, as a secularised form of Christian faith, in Black Mass, ${ }^{40}$ where he identifies the war in Iraq and the American attempt to export capitalist democracy there as "a utopian venture." ${ }^{\text {"11 }}$ By this, Gray means it is in line with all liberal and Enlightenment thinking that shares "a dream of ultimate harmony. ... The pursuit of a condition of harmony defines utopian thought and discloses its basic unreality." ${ }^{22}$ Gray classes Communism, Nazism and even (particularly in his earlier book: Al Qaeda and What It Means To Be Modern ${ }^{43}$ ) radical Islam as all similarly utopian projects, founded on the same utopian "myth". They all sought or seek the creation of an ideal world, a perfect human community. Gray

\footnotetext{
39 John Gray, Heresies: Against Progress and Other Illusions (London: Granta, 2004), 2.

40 Gray, Black Mass.

41 Ibid., 212.

42 Ibid., 23.

43 John Gray, Al Qaeda and What It Means To Be Modern (London: Faber \& Faber, 2003).
} 
writes:

Like Communism and Nazism, radical Islam is modern. Though it claims to be anti-Western, it is shaped as much by Western ideology as by Islamic traditions. Like Marxists and neo-liberals, radical Islamists see history as a prelude to a new world. All are convinced they can remake the human condition. If there is a uniquely modern myth this is it. $^{44}$

\section{THE ILLUSION OF HUMAN DIGNITY}

The error in Enlightenment thinking, and in particular in the belief in progress, is that it does not take into account the imperfectability of human nature and our inability to live in harmony with our environment. Gray outlines a philosophical anthropology in Straw Dogs that undermines any hope for a perfect human society, for the dream of progress. The idea that human beings can progress is, in Gray's view, a Christian idea. Even when this idea appears in Darwinist thinking, it is "formed from cast off Christian hopes." 45 Gray believes that the beliefs expressed in Christianity are the same ones that are expressed, albeit in secular garb, in humanist ideas.

Gray sees our being out of balance with the rest of the ecosystem as a distinctive feature of the human race. As we develop and grow as a species, we wreak havoc on the environment around us. "Throughout all of history...human advance has coincided with ecological devastation." 46 Our growing population and our misuse of the earth's resources will eventually end badly for the human species.

\footnotetext{
44 Gray, Al Qaeda and What It Means to Be Modern, 3.

45 Gray, Straw Dogs, 3.

46 Ibid., 7.
} 
Gray writes: "Humans are like any other plague animal. They cannot destroy the earth but they can easily wreck the environment that sustains them." ${ }^{\prime 47}$

In contrast to modern faith in progress, Gray predicts that the future will not be one of increasing rationality and mastery of nature through technological advance. Increases in technology, he points out, can be used as readily in the service of terrorism and tyranny as it can be used to further more altruistic human ends. "New technologies strengthen repressive governments as well as weaken them," writes Gray; "The rulers of China did not try to hush up the massacre in Tiananmen Square; they filmed it on video cameras and used it as a warning to others." ${ }^{\prime 8}$ Like the Christian faith in salvation, the belief in technological progress is simply that: a belief, without rational foundations. In fact, Gray considers a belief in progress through technological advance to be less rational than religious faith. $\mathrm{He}$ writes:

For many, the promises of religion lack credibility; but the fear that inspires them has not gone away, and secular thinkers have turned to a belief in progress that is further removed from the basic facts of human life than any religious myth. When they look to technology to deliver us from accidents, from choice and even from mortality, they are asking from it something it cannot give: a deliverance from the conditions that make us human. ${ }^{49}$

In Gray's view the renunciation of anthropocentrism leads to the conclusion that humanity need not necessarily have a future at all. Gray subscribes to the "Gaia

\footnotetext{
47 Ibid., 13.

48 Gray, Heresies, 22.

49 Ibid., 23.
} 
Hypothesis", which is "the theory that the earth is a self-regulating system whose behaviour resembles in some ways that of an organism," if the human population becomes imbalanced, nature will restore equilibrium through natural ecological processes. Gray predicts that the future of mankind will either mean further conflicts motivated by the scarcity of resources; a reduction through attrition of the human population to a size more supportable by the planet; or perhaps even the extinction of the human species itself. It is only our naive anthropocentric "faith" that prevents us from seeing the likelihood of this fate. $\mathrm{He}$ writes: "If humans disturb the balance of the earth they will be trampled on and tossed aside. Critics of Gaia theory say they reject it because it is unscientific. The truth is that they fear and hate it because it means that humans can never be other than straw dogs." ${ }^{51}$

\section{The Source of PluRal Values}

While much of Gray's work is focused on a critique of current political thought, he also outlines a constructive political philosophy that he believes to be the only viable option for politics in a pluralist society. Gray asserts that "the good" for any given culture or society springs from and cannot be separated from the particular "way of life" of that society. Goods can only be compared in particular social contexts. "Outside of their contexts in social practices, no value can be attached to goods such as justice and friendship. They acquire their meaning and

\footnotetext{
50 Gray, Straw Dogs, 32.

51 Ibid., 34.
} 
worth from the histories, needs and goals of human subjects and the ways of life to which they belong. Conflicts of value arise only in contexts given by forms of common life." ${ }^{52}$ Some goods can only be understood in their contexts, and can only be compared in these particular contexts where conflicts can arise. Other goods, despite being what Gray describes as "anthropological universals," ${ }^{13}$ can create conflicts that no other universal good can help to adjudicate between.

Gray's proposition that values spring from particular "ways of life", as opposed to being derived from universally authoritative, rational categories, is derived from Isaiah Berlin's "agonistic Liberalism", which presents a form of Liberalism based on values pluralism. Agonistic Liberalism argues that people's allegiance to any form of political life is often on the basis of a common culture or way of life protected by that regime, rather than to the rational principles that govern that political form. In fact, it is this common culture which gives rise to the values that shape a political structure. This is the source of values pluralism - what people value does not come from some universal humanity that they all share. Rather, they are the product of historic communities in particular contexts. Therefore, there are various ways of being authentically human. "This is, in effect," writes Gray, "to deny the philosophical anthropology of the Enlightenment, by affirming that human identities are always local affairs, precipitates of particular forms of common life, never tokens of the universal type of generic humanity. It is also to give the central thesis of value-pluralism ... a political statement, by observing that the conflict of values arises

\footnotetext{
52 Gray, Two Faces of Liberalism, 43.

53 Ibid., 44.
} 
in political life, most fundamentally on the rivalry of ways of life that are mutually exclusive, even where they are also internally complex." ${ }^{54}$

\section{MOdUS VIVENDI}

In view of the irreducible plurality of human identities and values, Gray argues that the form of Liberalism that must be pursued (if Liberalism is to have a future) is that form which provides for the peaceful coexistence of differing ways of life. In The Two Faces of Liberalism, Gray makes it clear that the form of liberalism that seeks "a rational consensus on the best way of life" 55 has no future. Rather, Liberalism as "a project of coexistence that can be pursued in many regimes" ${ }^{\prime 56}$ is the only form of Liberalism that Gray considers legitimate in our plural societies. If there are plural values, which cannot be reasonably arbitrated between, then the function of politics cannot be to institute a 'best' way of life (since that notion, for Gray, is nonsensical). Rather, values pluralism leads to, "a conception of political life as a sphere of political reasoning whose telos is a modus vivendi, to a conception of the political in which it is a domain devoted to the pursuit not of truth but of peace. ${ }^{37}$ The animating value for politics must be toleration and the pursuit of a modus vivendi - a peaceful coexistence - whereby all 'ways of life' that embody some form of human flourishing are allowed to exist and cohabit as far as that is possible.

Conceiving of the political project as the pursuit of modus vivendi then

\footnotetext{
54 Gray, Enlightenment's Wake, 79.

55 Gray, Two Faces, 1.

56 Ibid., 2.

57 Gray, Enlightenment's Wake, 74.
} 
prioritizes the need for negotiation and compromise in politics. The value of any political regime lies, then, not in its ability to promote a particular way of life, nor to protect a way of life through the legislation of "rights"; rather, its value lies in its ability to settle conflicts between various ways of life. As Gray contends: "the account of modus vivendi I have defended does not aim to prescribe principles of right that are independent of particular conceptions of the good. Instead, it judges regimes in terms of their capacity to mediate compromise among rival views of the good. The result is a liberal philosophy in which the good has priority over the right, but in which no one view of the good has overall priority over all others." ${ }^{58}$ As the pursuit of modus vivendi, politics becomes the arbiter of peaceful toleration, rather than institutionalising one way of life as best or ideal over all others.

\section{SUMMARY}

In summary, John Gray's main concern is to critique those versions of Liberalism that conceive of themselves as embodying universal values which should be adopted by all human cultures. Gray's critique stems from his assertion of values pluralism and his belief that it undermines the rational foundations that universal values rest on. Gray contends that the rationalism of (what he labels) "the Enlightenment Project", which seeks to define the ultimate human good, is a doomed project, undermined by the truth that many ultimate values are "incommensurable" and as such incombinable, such that no coherent definition of a human summun bonum is possible. Further, not only does Gray believe that ultimate

\footnotetext{
58 Gray, Two Faces, 135.
} 
goods are a chimera; he also asserts that the notion of 'progress' as continual improvement of human social and political institutions is likewise impossible and is more akin to a secular 'faith' than rational thought. The only realistic political project open to us, in Gray's view, is the realistic acceptance of plural values and the need for political negotiation in the pursuit of peaceful coexistence and a "modus vivendi"; a political space for all types of human flourishing in both Liberal and non-Liberal forms. Furthermore, Gray casts doubt even on the future of humanity as a whole, citing our anthropocentrism as an epistemological error inspired by Christian beliefs, which has lead to the destruction of our planet's resources. In Gray's opinion, the human population has become so large and out of harmony with the earth that an ecological adjustment of the population is imminent, arising either from conflicts engendered by the scarcity of resources, or else an ecological failure of the planet to support human consumption at present levels. The idea that belief in a human telos is an illusion is worth analyzing, since it is central to Christian claims about the world. It also has significance for the political project as a whole, as Gray has demonstrated. A key aspect of Gray's claim about teleological belief is that it is an illusion - but one that he describes as "necessary". 


\title{
CHAPTER 2: A HISTORY OF VIOLENCE
}

\author{
JoHN GRAY'S THESIS IN BLACK MASS
}

In Black Mass: Apocalyptic Violence and the Death of Utopia, ${ }^{1}$ Gray makes three significant claims about modern "apocalyptic violence" that are worth analyzing in depth here. The first is that modern politics is what he terms "utopian"; it is animated by the telos of a perfect world that it seeks to create. All such utopian thinking is doomed, in Gray's opinion, by the existence of plural and incommensurable values, which implies that there cannot be a single telos for human life toward which politics may strive. Gray's second claim is that all such utopian thinking in modern politics is merely the re-emergence of repressed (Christian) religious ideas. Specifically, Gray identifies anthropocentrism (the privileged place of human beings in the world) and teleology (the notion that human history has a goal, and hence, meaning) as two Christian fundamentals that have shaped the modern utopian (and broader Enlightenment) tradition. Both of these ideas he sees as erroneous, disproved, again, by the truth of values pluralism. However, despite being "illusions", he regards these ideas as necessary; illusions that human beings cannot seem to live without. His third claim is that utopian politics is ultimately violent. In the desire to create a perfect world in the future, the peace of the present is sacrificed. Those who use terror to create their utopias believe that human nature may be altered through the use of terror, so that a perfect society may be created. Finally, Gray proposes that a modus vivendi is a legitimate way to found

\footnotetext{
1 John Gray, Black Mass: Apocalyptic Religion and the Death of Utopia (London: Allen Lane, 2007).
} 
political regimes in a way that does not privilege a particular set of values over any other in society. The goal of a modus vivendi is to promote peaceful coexistence between a diversity of ways of life, without expecting society to converge on one particular set of ultimate values.

\section{THE FUTILITY OF 'UtOPIAN' POLITICS}

In Black Mass John Gray argues that modern politics is 'utopian'. By this he means that it seeks the creation of an ideal society. He writes: "Modern politics has been driven by the belief that humanity can be delivered from immemorial evils by the power of knowledge. In its most radical forms this belief underpinned the experiments in revolutionary utopianism that defined the last two centuries." 2 Among those political projects that Gray identifies as utopian, Communism is the most salient. However, Gray describes more recent political movements as also utopian; in particular he highlights the American invasion of Iraq as an attempt to apply the utopian ideal of capitalist democracy universally:

Towards the end of the last century the pursuit of Utopia entered the political mainstream. In future only one kind of regime would be legitimate: American-style democratic capitalism - the final form of human government ... Led by the United States, western governments committed themselves to installing democracy throughout the world. ${ }^{3}$

Like Communism before it, the modern "war on terror" and the attempt to establish democracy in Iraq is another attempt at creating an ideal world by political (and,

\footnotetext{
2 Ibid., 20.

3 Ibid., 40.
} 
eventually, by violent) means. It is merely the vision of perfection that has changed; the use of violence as a means to bring the ideal into existence stems from at least as far back as the French Revolution, as will be demonstrated later in this discussion.

Gray traces the use of the word "Utopia" to Sir Thomas More's book of $1515,{ }^{4}$ which described a perfect society. Since then, it has been used to refer to ideal communities, many religious, which have sprung up both to reform wider society and to escape from it. ${ }^{5}$ Gray begins with Isaiah Berlin's definition of utopianism, which is as follows:

All the Utopias known to us are based on the discoverability and harmony of objectively true ends, true for all men, at all times and places. [Utopian societies] rest on three pillars of social optimism in the West ... that the central problems of men are, in the end, the same throughout history; that they are in principle soluble; and that the solutions form a harmonious whole. $^{6}$

Gray reiterates Berlin's assertion that "a core feature of all utopias is a dream of ultimate harmony." All utopian thinking perceives an ideal system in which there is a lasting and harmonious peace, and they all seek to achieve this (impossible) set of conditions. It is this feature that ensures the failure of all utopian dreams.

The utopian dream of "ultimate harmony" is a flaw that dooms all such

\footnotetext{
4 Ibid., 21.

5 Ibid., 23.

${ }^{6}$ I. Berlin, 'The Apotheosis of the Romantic Will', in The Crooked Timber of Humanity: Chapters in the History of Ideas (London: John Murray, 1990) pp. 211-12, Cited in Gray, Black Mass, p. 22.

7 Gray, Black Mass, 23.
} 
projects. "The pursuit of a condition of harmony," writes Gray, "defines utopian thought and discloses its basic unreality. Conflict is a universal feature of human life." ${ }^{\prime 8}$ There is no possibility for a conflict-free existence for humanity - which is why every pursuit of one has failed. Gray regards all utopian thinking as 'flawed' precisely because it does not consider the problems of society to be reflections of its members; instead, utopian thinking identifies the source of society's problems as being the result of imperfect systems which repress humanity. Writing of the academic classes, Gray defines utopian thinking in them as: "the rejection of imperfectability in human affairs. It denies the idea cherished in the Christian and Jewish traditions that human life will always be imperfect and in some part tragic." It is this fundamental imperfection of human life that guarantees the failure of all utopian projects.

Gray defines utopian projects as "unrealizable" because they pursue a form of life which human beings are not capable of living, or because they try to achieve a transformation of human nature. ${ }^{10}$ He writes: "A project is utopian if there are no circumstances under which it can be realized." ${ }^{11}$ In particular he highlights any political vision of a society that is without the need for "coercion and power"; 12 however, he adds that a project is similarly utopian if it is "unrealizable under any

\footnotetext{
8 Ibid., 24.

9 John Gray, "Utopian academics and the collapse of communism," Academic Questions 5, no. 1 (March 1992): 67.

10 Gray, Black Mass, 28.

11 Ibid.

12 Ibid.
} 
circumstances - it is enough if it can be known to be impossible under any circumstances that can be brought about or foreseen." ${ }^{13}$ It is in this second category of utopianism that he locates the establishment of western-style democracy in post-Saddam Iraq; it is a project that he considers unrealizable. Gray criticizes those who have pursued it, for subscribing to an erroneous type of thinking which ascribes the history of intractable conflicts in Iraq to repressive political structures, rather than to a flawed and conflictual human nature. "For the utopian mind," writes Gray, "the defects of every known society are not signs of flaws in human nature. They are marks of universal repression." ${ }^{14}$ Therefore, Gray regards as utopian those projects that are founded on the belief that all human conflicts will be resolved under an ideal regime. They are utopian because they believe that "political action can bring about an alteration in the human condition." ${ }^{15}$ This idea, and its connection to the use of violence, will be explored in more detail in the latter part of this thesis.

For the same reason that Gray identifies utopian projects as unrealizable, he regards the modern idea of progress to be a "myth". In fact, he regards all "Enlightenment thinking" to be founded on the same error: the idea of history as progress. Gray identifies this animating belief as "faith" - as opposed to a fact. He describes this "Enlightenment faith" as the belief that "humanity is evolving towards a universal civilization." ${ }^{16}$ Bound up with this belief is "the myth that humanity is
13 Ibid.
14 Ibid., 29.
15 Ibid.
16 Ibid., 104. 
moving towards adopting the same values and institutions." ${ }^{17}$ For Gray, the foundation of the belief in progress and of Enlightenment thinking is the belief that humanity is converging on a universal culture and politics that will remove all conflict from human life. In Al Qaeda and What It Means to be Modern, ${ }^{18}$ Gray describes the Western "myth" of progress as the belief "that, as the rest of the world absorbs science and becomes modern, it is bound to become secular, enlightened and peaceful." ${ }^{19}$ It is faith in this telos of a peaceful and universal humanity that Gray considers an illusion. It is an illusion he believes to be disproven by the truth of values pluralism.

\section{Values Pluralism}

Values pluralism is an argument about the nature of reality, and of human nature, on which Gray's entire political theory rests. It is the view that there are many values that are incommensurable; that is, they cannot be compared, combined or otherwise rationally evaluated in order to establish either a hierarchy or a unified system of values. This perspective runs counter to much of the history of (Western) philosophy which, going at least as far back as Plato, has pursued an articulation of "the Good, the True and the Beautiful" as the ultimate goal of human life. In his Two Faces of Liberalism ${ }^{20}$ Gray argues for a form of Liberalism based on values pluralism. In his explication of values pluralism, he writes:

\footnotetext{
17 Ibid.

18 John Gray, Al Qaeda and What It Means to Be Modern (London: Faber and Faber, 2003).

19 Ibid., 118.

20 John Gray, Two Faces of Liberalism (Cambridge: Polity Press in association with Blackwell, 2000).
} 
The human good is shown in rival ways of living.... Value pluralism was a truth about human life before it was an inescapable social condition. There have been many attempts to explicate it. What all have in common is the proposition that there are many kinds of good life, some of which cannot be compared in worth. Some varieties of the good life are neither better nor worse than each other, nor the same in value, but incommensurable; they are differently valuable. Similarly, some regimes are neither more nor less legitimate than one another. They are legitimate for different reasons. ${ }^{21}$

Gray's understanding of values pluralism is largely drawn from the political theorist Isaiah Berlin, who advocates for a form of Liberalism that he calls "agonistic liberalism". In a chapter devoted to Berlin's agonistic Liberalism, Gray summarizes two of Berlin's central ideas: values pluralism and incommensurability.

Berlin's master idea is that ultimate values are objective and knowable, but they are many, they often come into conflict with one another and are uncombinable in a single human being or a single society, and that in many of such conflicts there is no overarching standard whereby the competing claims of such ultimate values are rationally arbitrable. Conflicts among such values are incommensurables, and the choices we make among them are radical and tragic choices. There is, then, no summum bonum or logos, no Aristotelian mean or Platonic Form of the Good, no perfect form of human life, which we may never achieve but towards which we may struggle, no measuring rod on which different forms of human life encompassing different and uncombinable goods can be ranked. ${ }^{22}$

Gray notes that the "distinctiveness and radicalism of Berlin's species of objective pluralism are easily missed." 23 As has been demonstrated in the previous chapter, it

\footnotetext{
21 Ibid., 34.

22 John Gray, Post-Liberalism: Studies in Political Thought (New York: Routledge, 1993), 65.

23 Ibid.
} 
is not to be confused with relativism, which denies the objectivity of values. Berlin agrees that ultimate values are objective and universal. But they can also be incommensurable.

Incommensurability is the key idea in understanding values pluralism. As outlined in the introduction, Gray discusses three kinds of incommensurability: Incommensurability between values, such as the competing demands made by justice and mercy; Incommensurability within values, such as the application of the value of freedom, when the freedom of the Paparazzi to take photos conflicts with the freedom of celebrities to have privacy; and incommensurability in the way that different cultures or ways of life honour different values, such as the difference between the Swiss who honour punctuality and Pacific Islanders who honour tolerance and acceptance. In each of these cases, the choice that is made between each value or each application of that value must be a radical choice as opposed to a rational choice. ${ }^{24}$ However, this does not mean that there can be no rational reasons for choosing between incommensurables - only that there is not one best way to choose between them. Gray writes: "If goods such as friendship and money cannot be compared in value, neither can the lives of people who make different choices between them. Yet such choices are not arbitrary. Our histories and circumstances, our needs and goals, may give good reasons for different choices." ${ }^{25}$

The decisions made between incommensurables are, in Gray's words,

\footnotetext{
${ }^{24}$ Gray, Two Faces of Liberalism, 65.

25 Ibid., 36.
} 
"agent-relative"; ${ }^{26}$ however, this does not mean they are purely subjective. It means that there are different ways of combining goods within a particular way of life. Many of them could be rationally judged to be of lesser value and many of them could be judged equally good. What incommensurability indicates is that there is no perfectly rational system for arbitrating between many values, because, as Gray writes: "The best life for human beings comes in many varieties, some of which cannot be combined. There is no one best or maximal form of life for humans." ${ }^{27}$ There is no one best way of life, of which all others are approximations. There are many ways to choose between incommensurables, and these will depend on the way a particular person chooses to combine them, in accordance with the many variables of their life, not on rational principles that logically privilege some values over others.

Values can be incommensurable and yet they can be compared and rationally compared within particular contexts and ways of life. Using the example of justice and friendship, while they may be incommensurables when discussed abstractly, they can be (and in practice must be, and regularly are) reasoned about and decided among in particular contexts. If I must choose between a promise made to a friend and a legally binding contractual agreement, only my context, with its history and conventions, can enable me to reason and choose between the two. "Outside of their contexts in social practices," writes Gray, "no value can be attached to goods such as justice and friendship. They acquire their meaning and worth from the histories, needs and goals of human subjects and the ways of life to which they

\footnotetext{
${ }^{26}$ Ibid.

27 Ibid., 39.
} 
belong." ${ }^{28}$ Many of the goods we value are socially determined; as explained above, the incommensurability of values sometimes arises from the different value accorded to goods by different cultures or ways of life. However, this is not to say that all human values are determined by their contexts. Gray writes: "Incommensurable goods are by no means always constituted by social conventions. Some are anthropological universals." ${ }^{29}$ This, inevitably, leads into questions of philosophical anthropology. To what extent is there a universal "human nature" with shared universal values? Is human identity just a construct of the social context in which it develops, or is there a generic core to what we are as human beings?

\section{Gray's PHILOSOPHICAL ANTHROPOLOGY}

Again, Berlin's thought underpins Gray's understanding of the source of human values and identity. And it is this understanding of philosophical anthropology that is at the core of Berlin's (and thus of Gray's) critique of both Liberalism and Enlightenment thinking: that human identities and values are not purely universal, but to a larger extent determined by our cultural and historical contexts. It is worth quoting Gray's summary of Berlin's thought on this point, at length:

\footnotetext{
It was a cardinal tenet of the Enlightenment that, whatever cultural variety the future of mankind [sic] would encompass, it was reasonable to expect convergence on a universal civilization undergirded by a shared, rational morality. If the upshot of Berlin's value-pluralism is to undermine the idea of a rational morality, the effect of his work on nationalism is to jettison the
}

\footnotetext{
28 Ibid., 43.

29 Ibid., 44.
} 
prospect that a time may come when men's dominant allegiance is to the norms of a universal civilization. The crux in Berlin's thought goes yet deeper than this. It is in a tension between the idea of a common human nature and the idea of human self-creation and self-transformation. If, as Vico, Herder and Berlin maintain, we are a highly inventive species whose forms of life are radically undetermined by our common humanity, what reason is there to share the hopes of the Enlightenment for an eventual convergence of liberal and humanistic values? ${ }^{30}$

Berlin's insight is one that runs counter to much of modern thinking: being human is not a universally shared experience, identical wherever it is found.

Human beings are children of place and history, and their identities are as much a self-creation (in fact more a self-creation, in Berlin's thinking) than an inherent "human nature" that is common to all. And this self-created nature is core to our identity - not a surface feature of a deeper, universal humanity. The error of conceiving of human beings as "abstract instances of the human species," 31 is one that Gray locates as present in the heart of all utopian regimes. For example, Gray critiques Marxist philosophical anthropology as follows:

[It] seeks to expunge the cultural inheritances of mankind, and thereby also to roll back the most powerful achievements of the modern world in the interests of a mythic entity - that of universal humanity. ... Marxian philosophical anthropology is committed to the view that all the forms of human identity which have achieved concrete historic realization are aberrations, unavoidable episodes (perhaps) in the growth of human

\footnotetext{
${ }^{30}$ Gray, Post-Liberalism, 68 emphasis mine.

31 Ibid., 254.
} 
productive powers, but nevertheless episodes which conceal rather than disclose the human essence. ${ }^{32}$

It is this "myth" of universal human nature which values pluralism serves to unmask, and which by extension undermines the concomitant myth of a universal ideal for society, which Gray insists is the animating telos of Liberalism, the belief in progress and the entire Enlightenment project of Western society.

Gray's early work focused his critique on Liberalism and its pretensions to universal authority by claiming to be founded on universal human values. In his analysis of Liberalism's foundations, Gray highlights its limited understanding of human nature which ignores the historical and culture-bound aspects of the liberal human being, universalizing for all times and all peoples, traits which have arisen out of a specific cultural history. Gray concludes:

If the supposedly universal principles of liberal political morality dissolve into indeterminacy on analysis, we can then begin to perceive the spuriousness of liberal notions of universal humanity and abstract personhood - notions whose only value is to summarize or abbreviate (very imperfectly) certain passages in the historic experience of specific liberal societies. A central disability of liberal ideology, then, in addition to the indeterminacies infecting its constitutive principles, is its blindness to the historical singularity of its distinctive forms of self-identity and self-understanding. If we abandon the delusive perspective of universality, however, then we can see liberal society as a historical achievement, an inheritance of institutions and traditions which informs our thought and practice in profound ways, but which we are bound to acknowledge has no universally apodictic character. ${ }^{33}$

\footnotetext{
32 Ibid., 255.

33 John Gray, Liberalisms: Essays in Political Philosophy (London: Routledge, 1989), 240.
} 
It is this understanding of the hegemony of Liberalism that informs Gray's understanding of modern political positions. His central critique of modern politics is of the tendency to enshrine in universal terms a particular, historical form of human self-understanding and to seek to make it applicable to all people and all cultures, ignoring the way that human identities spring from culture, tradition, practices and "ways of life".

However, not only does Gray reject the notion that humanity is a universal essence that we are all instances of; he also critiques the claim of communitarians, that contextualized human identities are singular and uniform and are best represented by nationalist politics. In Gray's view, while the forms of life in which we participate largely constitute our particular identities, we are no more defined by these contexts than we are by any universal human essence. Gray writes:

$$
\begin{aligned}
& \text { The conservative theorist, like the communitarian critic of liberalism from the } \\
& \text { Left, moves unreflectively from the truth that we are none of us } \\
& \text { [un]encumbered or disembodied selves to the very different, and indeed } \\
& \text { manifestly false proposition that we are, or ought to be radically situated } \\
& \text { selves - that is to say ... selves whose identity is contoured by membership } \\
& \text { in a single moral community and mirrored in the institutions of a single } \\
& \text { political order. }
\end{aligned}
$$

Rather, Gray insists that human identity is more complex; we are the products of various - and at times conflictual - inheritances and traditions. This is essential to being human, since "the power to conceive of ourselves in different ways, to harbor dissonant projects and perspectives, to inform our thoughts and lives with divergent

\footnotetext{
${ }^{34}$ Gray, Post-Liberalism, 261.
} 
categories and concepts, is integral to our identity as reflective beings." ${ }^{35}$ It is this belief that there is no "deep, undergirding moral community" in our modern societies, which leads Gray to conclude: "government is ill-fitted to act as guardian or protector of any of the traditions it shelters." ${ }^{\prime 36}$ It is also what prompts him to offer his constructive proposal of modus vivendi as the best model of government in a pluralist society.

However, Gray does believe there is such a thing as 'human nature'. What, then, remains if we are neither defined by a universal nature, nor by the notion of a uniform, local identity? Gray believes that what human beings share (along with all other animals) is that we are motivated by our needs - our conflicting and animal needs. Gray insists that: "the Counter-Enlightenment belief that there is no such thing as human nature is as much an illusion as the Enlightenment idea of universal humanity. Like other animals, humans have a common nature that is fairly constant in its needs. It is this common nature that underlies universal goods and evils. It is also what accounts for their universal conflicts." ${ }^{37}$ Again, in Black Mass, Gray asserts:

Contrary to the thinking of post-modernists who believe all human values are cultural constructions and reject the idea of human nature, there are some values that reflect universal human needs. But these needs are many and discordant, and universal values can be embodied in different ways. ${ }^{38}$

\footnotetext{
35 Ibid., 263.

36 Ibid., 265.

37 Gray, Two Faces of Liberalism, 20.

${ }^{38}$ Gray, Black Mass, 279.
} 
We are not creatures finely tuned to perceive the rational or moral nature of the universe and to structure our lives accordingly. Rather we are "like other animals"39 without meaning or destiny. We are not the autonomous, rational, moral beings that we presuppose; rather: "Like other animals, we are embodiments of universal Will, the struggling, suffering energy that animates everything in the world." ${ }^{40}$ We have universal needs - like the need to survive and to flourish. But even these most universal features of human nature cannot undergird a universally applicable form of life, since they conflict with each other. As Gray explains:

Universal human values are often rivals. When universal values collide there are no universal principles for settling their conflicts ... Which is better - a regime which ensures peace but in which many are malnourished or one that is plagued by fatal violence but in which no-one starves? There is no answer that all reasonable people are bound to accept. ${ }^{41}$

This example illustrates Gray's position that our needs, while universally felt, are conflictual and not reducible to a coherent, rationally unified system of thought.

Gray maintains the existence of "universal evils". These evils are defined in reference to Gray's affirmation of universal human needs. Some evils are universal in that they stifle needs that are universal. Gray explains:

The claim that there are generically human evils ... rests on the fact that the experiences to which these evils give rise are much the same for all human beings, whatever their ethical beliefs may be. The constancy with which these experiences are found, across remote cultures and distant epochs,

\footnotetext{
39 Gray, Two Faces of Liberalism, 20.

40 Gray, Straw Dogs, 41.

41 Gray, Two Faces of Liberalism, 44-5.
} 
reflects a constancy in human nature, not an agreement in opinions. Like other animals, humans have a stock of needs that does not change much, and which constrains the forms of life in which they can thrive. Whenever the thwarting of a generically human need renders a worthwhile life unattainable, there is a universal evil. ${ }^{42}$

There are universal needs, and the 'thwarting' of these needs is an evil that is universal. Hence, the forms that the 'good' human life can take are limited by these needs. In order for a way of life to be a 'good' form of life, it needs to be one in which the universal human needs are catered for. Gray does not seek to define what the human needs are, nor does he define the correlative 'evils' which apply to all. He insists: "There can be no definitive list of the conditions which endanger a worthwhile human life." ${ }^{43}$

However, Gray identifies some of the general kinds of "evils" which this list of "universal evils" would contain: "to be tortured ... to be separated from one's friends, family or country; to be subjected to humiliation or persecution or threatened with genocide; to be locked in poverty or avoidable ill-health - these are great evils for all who suffer them." 44 These universal evils are, like universal needs, incommensurable, in that they cannot all be avoided equally. Rather, "differing ways of life come partly from divergent settlements among universal evils." 45 While these universals cannot underwrite the universalizing of a particular way of life, they can

\footnotetext{
42 Ibid., 66.

43 Ibid.

44 Ibid.

45 Ibid.
} 
mark out the boundaries of "the good life" and hence can in some way make universal moral claims. Gray explains:

Strong pluralism does not reject all universal moral claims. It does not deny that there are universal, pan-cultural goods and bads. It affirms their reality. It sees such universal values as marking boundary conditions beyond which worthwhile human lives cannot be lived. ${ }^{46}$

Gray does not resist the universalizing of the general values of "the good life" or "human flourishing"; rather, he resists any particular settlement of values that claims to be the one, unique form of the good life. The good life, for Gray, is plural.

This clarifies Gray's thought on universal values in important ways. Incommensurability is not the claim that there are no universals to guide human life. In Gray's view, we have definite needs, the fulfillment of which is a good and the thwarting of which is an evil. What incommensurability claims is, firstly, that human societies are not perfectible. By this Gray means a very specific kind of perfectibility: one where every good is maximized and every evil minimized to the highest degree. "No regime can truly claim to embody the best settlement of conflicts among universal values." 47 There will always be different settlements of conflicts in value that are equally valid.

This leads us to the second insight that Gray draws from the incommensurability of values: human life can flourish equally well in a variety of regimes. He writes: "Disputes about which regime is everywhere best are without

\footnotetext{
46 John Gray, "Where Pluralists and Liberals Part Company.," International Journal of Philosophical Studies 6, no. 1 (March 1998): 23.

47 Gray, Two Faces of Liberalism, 67.
} 
sense. The diversity of regimes is like the diversity of goods. It is not a mark of any lack in human life. It is a sign of the abundance of good lives that human beings can live." 48 Elsewhere he writes: "Strong value pluralists believe that there are irreducibly many varieties of human flourishing." 49 This is among the most positive of statements that Gray makes concerning politics and human life. Incommensurability is, from one side, a celebration of the plurality of equally good lives that human beings can live. From another side, it is used to undermine the notion of human life having any kind of telos or sense of meaning. For Gray, a telos must be a monadic vision without room for diversity or plurality. There can be only one "good" if human life is to have a meaning that can orient its progress toward an ideal society.

This reveals a further distinction in Gray's thinking that is subtle but important to understanding his argument. There can be no universal incarnation (to use a word that, while philosophically loaded, will be useful in my later critique of Gray) of the universal goods in human life. While there are universal goods (which Gray attests to, even if he does not seek to define them), they cannot be applied to human life in one best way. He writes: "Different regimes need not be approximations to any ideal type. Indeed they cannot be." 50 This is because there can always be another way of "incarnating" the universal goods which is equally as good as another. That truth cannot be reduced to a single incarnation in human life disproves its existence to Gray. His implicit assumption is that truth must lead to a singular outcome if it is to

\footnotetext{
48 Ibid., 67-8.

49 Gray, "Where Pluralists and Liberals Part Company.," 19.

50 Gray, Two Faces of Liberalism, 67.
} 
have a universal claim. It is useful to quote Gray at length on this crucial idea: Objective pluralism carries with it the implication that there is a radical moral scarcity which it is our fate as humans to endure. In the form in which it is most subversive of the classical foundations of Western civilization, this species of pluralism denies the coherence of the Form of the Good, as theorized by Plato, and rejects the thesis of the unity of the virtues, as advanced by Aristotle. In this pluralist view, not only are all genuine goods not necessarily harmonious, but goods may depend for their existence upon evils, virtues on vices. In this aspect, pluralism is a variation on the theme of the imperfectability of human life, traceable back to Jewish and Christian sources. In its deepest implication, however, pluralism does not mark the imperfection inherent in the nature of things: it destroys the very idea of perfection. It thereby strikes a death-blow at the classical foundation of our culture, expressed not only in Plato and Aristotle, but in the Stoic idea of the logos and in Aquinas's conception of a world order that was rational and moral in its essence, even as it was the creation of the Deity, one of the central attributes of which was perfection. ${ }^{51}$

It is at this point that Gray's philosophical anthropology and his epistemology meet. Given the plurality of ways that values can be worked out, Gray concludes that human life is meaningless. Human beings are without meaning and the world is without meaning. Human values cannot be combined into a unified, universally coherent and valid system of ideas, as the history of Western philosophy has often presupposed, because they stem from our conflicting, animal needs; not from an assumed correlation between our rational ideas of ourselves and the actual nature of the world.

From the incommensurability of values, the conclusion that there is no single,

51 Gray, Post-Liberalism, 291. 
rational ideal for human life follows: "If rational inquiry has failed to produce agreement on the best life, it is not because of any imperfection in human reason. It is because the idea of perfection has no sense in human life." ${ }^{\text {"2 }}$ The idea that there can be one vision of "the Good, the True and the Beautiful" is false. If there are a myriad of values that can be regarded as acceptable, then there are, likewise, a myriad of "goods" towards which human beings may reasonably strive. Hence, there can be no single, perfect ideal for human life that is universal for all people. Humanity will strive for varying goods; goods which are incommensurable and which will inevitably produce conflict when they are combined in a single society, or even when they are combined in a single life.

Not only does Gray regard the pursuit of a rationally ideal life as pointless, he attacks even the notion that human life has meaning at all. In Straw Dogs, in particular, Gray argues that anthropocentrism - regarding humanity as the most important feature of existence - is an error that underpins the history of (at least Western) philosophy:

Philosophers from Plato to Hegel have interpreted the world as if it was a mirror of human thinking. Later philosophers such as Heidegger and Wittgenstein went further, and claimed that the world is a construction of human thought. In all these philosophies, the world acquires a significance from the fact that humans have appeared in it. In fact, until humans arrive, there is hardly a world at all. ${ }^{53}$

This is the error that lies at the heart of all regimes that try to find meaning in human

\footnotetext{
52 Gray, Two Faces of Liberalism, 39.

53 Gray, Straw Dogs, 53.
} 
life and history. All such systems mistakenly try to capture and enshrine the "essence" of human nature in a rational system of ideas. But human existence is not reducible to a unified system of thought. To assume that it is, is to assume a meaning for human existence that Gray denies and that he insists is a pervasive error in Western philosophical anthropology. Gray traces the foundations of this error back to both Greek logo-centrism and to Christian faith.

Gray locates the source of anthropocentrism in "Realism" that, he argues, has its source in written language. It is in capturing the world in written language that the first error in Western philosophy was made. "Writing creates an artificial memory, whereby humans can enlarge their experience beyond the limits of one generation or one way of life," writes Gray; "At the same time it has allowed them to invent a world of abstract entities and mistake them for reality." 54 He continues: "Plato was what historians of philosophy call a realist - he believed that abstract terms designated spiritual or intellectual entities." ${ }^{55}$ Elsewhere, Gray describes the Enlightenment as "an authentic development of a central Western tradition going back to Socrates, and indeed beyond ....in whose fragments the fundamental commitments of Greek logocentrism - which I understand as the conception in which human reason mirrors the structure of the world - are affirmed."

In opposition to this error, Gray asserts a kind of Taoistic, non-rational

\footnotetext{
54 Ibid., 56.

55 Ibid., 57.

56 John Gray, Enlightenment's Wake: Politics and Culture at the Close of the Modern Age (New York: Routledge, 1995), 152.
} 
apprehension of the world. He sees hints of this in Heidegger's later thought, in his concept of "Gelassenheit" (or "releasement"), "in which we let things be rather than aiming willfully to transform them or subject them to our purposes." 57 The concluding sentences of Straw Dogs summarize his approach to the notion of human reason and meaning: "Other animals do not need a purpose in life. A contradiction to itself, the human animal cannot do without one. Can we not think of the aim of life as being simply to see?"58 While it is outside the scope of this discussion to pursue Gray's reading of Gelassenheit and his proposal that human rationality should be focused on "seeing" rather than conceiving, it is clear that Gray believes that anthropocentric and teleological thought are entwined human-centered thinking animates the belief in human destiny or meaning; and he believes them both to be mistaken.

\section{THE CHRISTIAN ROOTS OF ANTHROPOCENTRISM, UtOPIAN THINKING} and Modern Political Violence

Gray traces utopianism and Enlightenment thinking, by way of anthropocentrism, back to Christian roots. Anthropocentrism is animated by Christian beliefs. For the Christian "everything of value in the world emanates from a divine person, in whose image humans are made." 59 Gray believes that once Christian foundations are renounced, so the notion of the value of personhood is baseless. He continues: "once we have relinquished Christianity the very idea of the

\footnotetext{
57 Ibid., 153.

58 Gray, Straw Dogs, 199.

59 Ibid., 58.
} 
person becomes suspect." 60 Elsewhere, Gray makes explicit the connection between Christianity and the Enlightenment. He writes:

In Christian theism, value is an emanation of personality, human or divine; human beings have infinite worth because they partake of the divine personality that created them. ... Denuded of its theistic framework and content, the idea of the human species as the source of value in the world, and of human relations with nature being instrumental ones in which human activities alone are value-creating, emerges in modern times as secular humanism, which from the Renaissance onwards is a defining element in the modern world-view. It is integral to the humanist conception of humankind and of its relations with nature, as this figures in the Enlightenment project and in its predecessor Christian world-view. ... Indeed one of my central arguments is that modern Enlightenment humanism is continuous with and in large measure a modification of Christian humanist conceptions of humankind and the world. ${ }^{61}$

This idea stands at the centre of Gray's thesis in Black Mass and is central for much of his thought. In his view, anthropocentrism is an error in thinking that is based on theistic ideas. Once theistic ideas have been renounced, anthropocentrism is no longer valid.

Gray also posits the Christian hopes of salvation and "world renewal" as the foundation of modern utopian thought. Christianity, in Gray's account of it, has always had inherent in it the idea of progress: "A belief in moral progress has always been part of Christianity, but it remained dormant until the Reformation. Puritans served as a vehicle for the idea - often called post-millennialism - that human effort

\footnotetext{
60 Ibid., 58.

61 Gray, Enlightenment's Wake, 158-9.
} 
could hasten the arrival of a perfect new world."62 Christians believe that God will one day renew the heavens and the earth, bringing a perfect world into being. It is this idea that Gray sees as being adopted by Enlightenment thinkers and which inspires their dreams of utopia. Gray writes: "As we understand it today, utopianism began to develop along with the retreat of Christian belief. Yet the utopian faith in a condition of future harmony is a Christian inheritance, and so is the modern idea of progress." ${ }^{\circ 3}$ Utopian ideals and the belief in progress are merely secular forms of the Christian hope of salvation.

In particular, Gray sees Christian millenarian belief as the source of modern utopian thinking. Gray asserts: "Christian millenarians believe that Jesus will return to the Earth and rule over it in a new kingdom for a thousand years," ${ }^{64}$ and hence, "millenarians hold to an apocalyptic view of history." ${ }^{65}$ By "apocalyptic", Christians refer to the unveiling of God's plans for the world, "and for the Elect this means not catastrophe but salvation. ...Jesus and his first disciples believed that the world was destined for imminent destruction so that a new and perfect one could come into being." ${ }^{66}$ An analysis of the accuracy of Gray's characterization of Christian eschatological belief will be made in the following chapter. But it is clear that Gray considers Christianity to be the source of the idea of a purpose or destiny for human

\footnotetext{
62 Gray, Black Mass, 30.

63 Ibid., 29.

64 Ibid., 5.

65 Ibid.

${ }^{66}$ Ibid.
} 
history.

The teleological view of human history is a Christian inheritance. Christian millenarianism is teleological. It believes that there is a telos or "end" for human history. Gray attributes modern teleological belief to the adoption of an essentially Christian view of history. Gray Writes: "Christianity injected the belief that human history is a teleological process." ${ }^{\prime 67}$ On this point it is worth quoting Gray at length:

$$
\begin{aligned}
& \text { In thinking of history in teleological terms, Christians believed it had an end in } \\
& \text { both senses: history had a pre-determined purpose, and when that was } \\
& \text { achieved it would come to a close. Secular thinkers such as Marx and } \\
& \text { Fukuyama inherited this teleology, which underpins their talk of 'the end of } \\
& \text { history'. In that they view history as a movement, not necessarily inevitable } \\
& \text { but in the direction of a universal goal, theories of progress also rely on a } \\
& \text { teleological view. Standing behind all these conceptions is the belief that } \\
& \text { history must be understood not in terms of the causes of events but in terms } \\
& \text { of its purpose, which is the salvation of humanity. This idea entered western } \\
& \text { thought only with Christianity, and has shaped it ever since. }
\end{aligned}
$$

Here, Gray unites several strands of his thinking; he combines anthropocentrism and a teleological view of history with universal values. For Gray, the vision of a universal, human meaning to history is a fundamental error, founded in Christianity, which, in secular form, has birthed the Enlightenment and the modern belief in progress.

Gray's understanding of Christianity, drawing on the work of scholars such as Albert Schweitzer and Norman Cohn, posits eschatological hope as a central, yet contested theme in the history of Christian thought. Gray describes Jesus'

\footnotetext{
67 Ibid., 6.

68 Ibid., 6-7. Emphasis mine.
} 
teachings as "eschatological" and as "grounded in the belief that humanity was in its final days." ${ }^{\circ 9}$ Gray claims that Jesus' "radically dualistic view of the world" was at odds with biblical Judaism, ${ }^{70}$ and that he "belonged in a heterodox current of mainstream Judaism." ${ }^{.11}$ Jesus came announcing the imminent arrival of the end of the current world and the establishment of a new world that is "without corruption." However, the "new kingdom did not arrive, and Jesus was arrested and executed by the Romans. The history of Christianity is a series of attempts to cope with this founding experience of eschatological disappointment." ${ }^{73}$ Consequently a belief in Jesus' resurrection "sprang up" amongst his followers; a belief that was soon after interpreted as "a metaphor for an inner change." 74 The apostle Paul was the one who universalized the ideas of this marginal Jewish sect and established a "universal religion." ${ }^{75}$ Augustine, influenced by Platonism, further transformed Jesus' message into an allegory for spiritual change. Gray writes: "By de-literalizing the hope of the End, Augustine preserved eschatology while reducing its risks. The kingdom of God existed in a realm out of time, and the inner transformation it symbolized could be realized at any point in history." ${ }^{76}$ Gray concludes his discussion of Christian origins

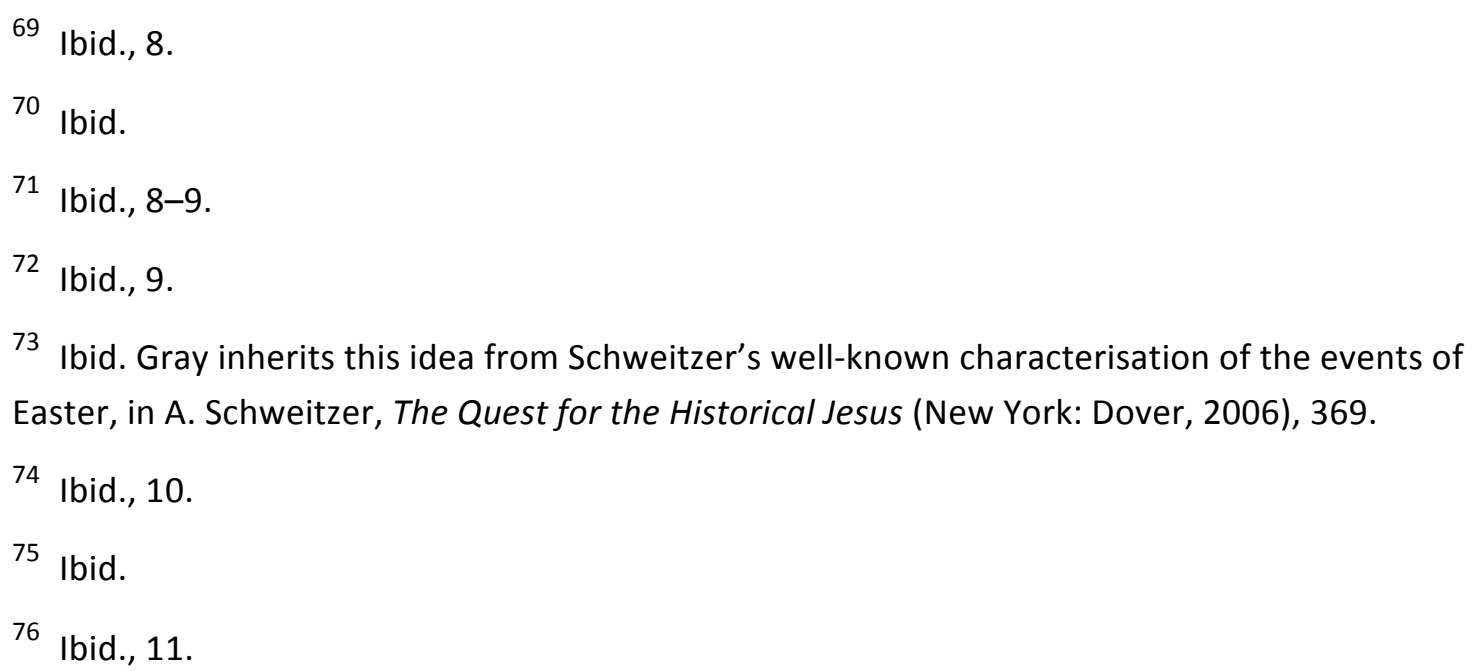


by declaring that "Christianity injected eschatology into the heart of Western civilization, and despite Augustine it has reappeared time and again.. ${ }^{77}$ While a more in-depth analysis of the role of eschatology in Christian thinking will be made later, it is worth noting that Gray's reading of Christian theology is largely a marginal one.

\section{UTOPIA AND VIOLENCE}

Gray argues that utopian projects are not merely unachievable, but ultimately violent. He cites examples of modern utopian projects, built on the "Enlightenment faith" in progress, which turned to violence as a means of achieving their ends. $\mathrm{He}$ includes Nazism, Communist Russia and (controversially) radical Islam, as examples of twentieth-century political projects that aim to create an ideal world and that turn to violent means to bring this world into being. They are all used to illustrate his point that: "The use of inhumane methods to achieve impossible ends is the essence of revolutionary utopianism." ${ }^{78}$ If ultimate human salvation is possible in the future, then so valuable an end mitigates sacrifice and violence as present means.

Gray locates the source of modern political terror in the roots of the French Revolution. He argues that terror first came to be seen as "an instrument for perfecting humanity"79 by the Jacobins, an eighteenth-century group that influenced the French Revolution. Driven by the belief that society had become corrupt because of repression and that it could be transformed by force, the Jacobins used terror as "a technique of civic education and an instrument of social engineering ... A higher

\footnotetext{
77 Ibid., 16.

78 Ibid., 25.

79 Ibid., 36.
} 
form of human life was within reach - even a higher type of human being - but only once humanity had been purified by violence." ${ }^{80}$ One of the central fallacies held by those who use terror for political means in modern times is the idea that human nature can be altered. Gray asserts that those who engage in terror for political purposes do so in the belief that they will be able to bring about a change in human nature by their actions.

It is this same idea, inspired by Enlightenment ideals of a telos for humanity, and coupled with modern faith in science and progress - that human nature can be transformed into its perfect form - that underpinned the catastrophic violence of twentieth-century politics. "At its worst," writes Gray, "twentieth-century terror was used with the aim of transforming human life. The peculiar quality of twentieth-century terror is not its scale. ... It is that its goal was to perfect human life." ${ }^{" 1}$ Gray illustrates this using the example of the Bolshevik revolution in Russia. He identifies the belief that human nature can somehow be transformed in the writing of Trotsky. Gray writes: "In Trotsky's view history is the process in which humanity gains control of itself and the world. ... Trotsky's vision in which science is used to perfect humanity expresses a recurrent modern fantasy. ...From the start the Bolsheviks aimed to create a new type of human being." ${ }^{\prime 2}$ Gray sees this modern line of thinking running through all utopian regimes that seek to transform societies and ultimately human nature itself, into a more perfect form, through the use of terror

\footnotetext{
80 Ibid., 37.

81 Ibid., 53.

82 Ibid., 56-7.
} 
and violence. With the Jacobins, Gray remarks "The era of political mass murder had arrived." ${ }^{83}$ Violence as a political tool began with the Jacobins and has persisted in modern politics. Gray lists Mao, Pol Pot and radical Islamic movements as just some of the many political groups who have similarly embraced violence as a liberating power in the twentieth-century. ${ }^{84}$

The turn to violence hinged on the abandonment of the Christian faith that God would bring about salvation for humanity. It was the shift from belief in divine intervention that would create the perfect world, to human intervention and the use of violence as the means of bringing about the perfect human society that has marked twentieth-century politics and opened the door to the terror and unparalleled political violence of recent history. With the decline of Christian beliefs, what Gray terms "modern secular religion" rose and with it the kind of revolutionary utopianism that did not shrink from the use of violence to reshape the world. ${ }^{85}$ Gray identifies the source of political violence as resulting from the secularization of Christian hopes for salvation. This is the crux of his argument:

If Christianity sparked a hope of world-renewal that had not existed in the ancient world it also spawned a new type of violence. The Christian promise of universal salvation was inherited by its secular successors. But whereas in Christianity salvation was promised only in the life hereafter, modern political religions offer the prospect of salvation in the future - even, disastrously, the near future. In a seeming paradox, modern revolutionary movements renew the apocalyptic myths of early Christianity.

\footnotetext{
83 Ibid., 38.

84 Ibid., 37.

85 Ibid., 39.
} 
With the Jacobins, that utopianism became a revolutionary movement and modern secular religion a political force. Post-millennialist Christians propagated beliefs that mutated into the secular faith in progress; but so long as history was believed to be governed by providence there was no attempt to direct it by violence. While Christianity was unchallenged, Utopia was a dream pursued by marginal cults. The decline of Christianity and the rise of revolutionary utopianism go together. When Christianity was rejected, its eschatological hopes did not disappear. They were repressed, only to return as projects of universal emancipation. ${ }^{86}$

Christianity gave the world hope for salvation. But when those hopes were divorced from a divine agency to achieve them, they fuelled political violence and terror, which were deployed in the service of the creation of a perfect world.

Utopian political thinking and its inherent violence have in recent years entered the mainstream, manifested most clearly in the politics of the United States. The utopian ideal for the United States, and indeed for much of the Western world, is "American-style democratic capitalism." ${ }^{87}$ Western governments have followed the United States in a mission to install democracy throughout the world. Gray condemns this move as "an impossible dream that in many countries could only produce chaos." ${ }^{88}$ Coupled with the "war on terror", this kind of politics has repeated the pattern of other utopian political endeavours of the twentieth-century it has become violent. Gray outlines the ways in which this has been manifested:

[The United States] was prepared to engage in pre-emptive attacks on sovereign states in order to achieve its goals, while at the same time it has

\footnotetext{
86 Ibid., 38-9.

87 Ibid., 40.

88 Ibid.
} 
been ready to erode long-established American freedoms. It has established a concentration camp in Guantanamo whose inmates are beyond the reach of normal legal protection, denied the protection of habeas corpus to terrorist suspects, set up an apparatus of surveillance to monitor the population and authorized American officials to practice what in any other country would be defined as torture. ${ }^{89}$

The most recent and dramatic example of this "impossible dream" of installing democracy throughout the world has been the war in Iraq. The United States and its allies have attempted to install a Western-style democracy in Iraq; a project that Gray describes as "unrealizable." 90 In fact, Gray describes the outcome as an "American defeat in Iraq." ${ }^{91}$ He writes: "The perception fostered by the Bush Administration that Iraq has a fledgling government that is rebuilding the country has no basis in reality.... The Iraqi state has disappeared into history's memory hole."92

\section{CHRISTIANITY AS UBIQUITOUS ILLUSION}

The re-emergence of repressed Christian hopes is another central idea for Gray. Religion is an illusion, but it is a necessary illusion in that it answers to universal human needs. "Religions have served many purposes," writes Gray, "but at bottom they answer to a need for meaning that is met by myth rather than by explanation. A great deal of modern thought consists of secular myths - hollowed out religious narratives translated into pseudo-science." 93

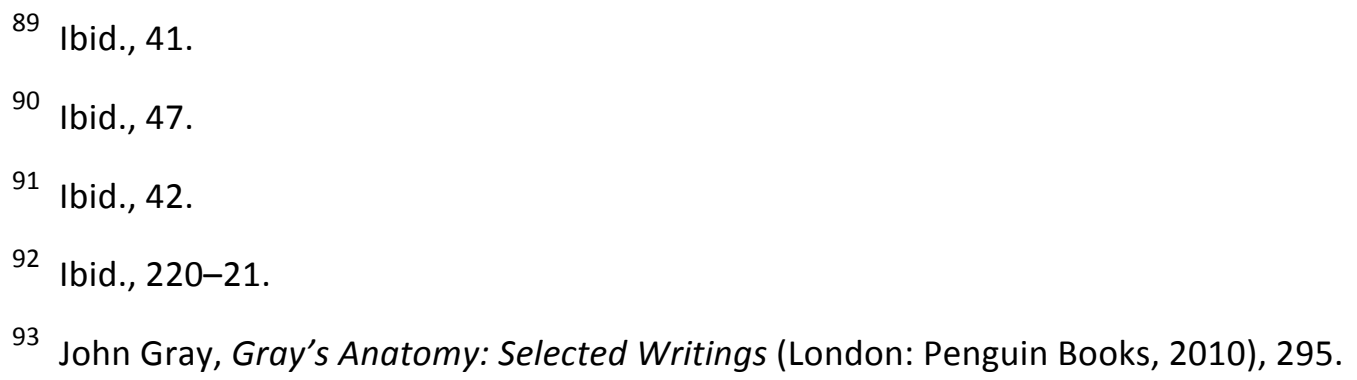


The myth that Gray most readily identifies as a "hollowed out religious narrative" is that of human meaning in history. Gray writes: "Humans cannot live without illusion. For the men and women of today, an irrational faith in progress may be the only antidote to nihilism." ${ }^{94}$ But this need for meaning is one that Gray regards as a universal human need that, while it may be an illusion, is not one that can be eradicated. Gray believes that this is something that early secular thinkers understood. He writes:

Marx held to a reductive view in which religion was a by-product of oppression; but he was clear it expressed the deepest human aspirations - it was not only the opiate of the masses but also 'the heart of a heartless world'. The French Positivists wanted to replace Christianity by a ridiculous Religion of Humanity; but they understood that religion answered to universal human needs. Only a very credulous philosopher could believe that showing religion is an illusion will make it disappear. ${ }^{95}$

For Gray, even though religion is an illusion, it is not one that will go away. Human beings have a universal, irrational need for meaning. Religion answers to that need. When religion is repressed, the desire for meaning re-emerges in other forms. "Religion has not gone away," writes Gray. "Repressing it is like repressing sex, a self-defeating enterprise ... To attempt to eradicate religion ... only leads to it reappearing in grotesque and degraded forms." ${ }^{96}$ And Gray believes modern instantiations of the need for meaning have begotten these "degraded forms"; whether Nazism, Communism, fundamentalist Islam or what Gray calls American

\footnotetext{
94 Gray, Straw Dogs, 29.

95 Gray, Black Mass, 267.

${ }^{96}$ Gray, Gray's Anatomy: Selected Writings, 302.
} 
"armed missionaries," 97 forms of "salvation" which have jettisoned the place of God all turn to human devices, and ultimately to terror and violence to achieve their aims.

Gray describes utopian political regimes as "political religions" and as secular successors to Christian faith. Inasmuch as they inhabit and propagate the old myths of human destiny and a utopian salvation for mankind, they are examples of the re-emergence of the myths that were formerly advanced by religion. It is in understanding modern politics in this way which leads Gray to open Black Mass with the provocative statement that: "Modern politics is a chapter in the history of religion." ${ }^{98}$ Gray continues:

\begin{abstract}
The greatest of the revolutionary upheavals that have shaped so much of the history of the past two centuries were episodes in the history of faith moments in the long dissolution of Christianity and the rise of modern political religion. The world in which we find ourselves at the start of the new millennium is littered with the debris of utopian projects, which though they were framed in secular terms that denied the truth of religion were in fact vehicles for religious myths. ${ }^{99}$
\end{abstract}

Secularism has not thrown off the myths that are inherent in Christian faith; rather, it has propagated them in mutated forms that have engendered violence and terror. Writing of the regimes of Mao and Stalin, Gray asserts: "They were demonstrating what happens when atheism becomes a political project. The invariable result is an ersatz religion that can only be maintained by tyrannical

\footnotetext{
97 Gray, Black Mass, 206ff.

98 Ibid., 1.

99 Ibid.
} 
means." ${ }^{100}$ In the failure of these political religions Gray sees the genesis of a renewal of faith as a force in the political realm. In particular, he sees the American defeat (as he describes it) in Iraq as the last gasp of secular political religion, opening the door for the myths of salvation and human meaning to once again be animated by faith, rather than by the faith in science and progress that has largely lost credibility. Gray writes:

\begin{abstract}
When the project of universal democracy ended in the blood-soaked streets of Iraq, this pattern [of belief in secular utopias] began to be reversed. Utopianism suffered a heavy blow, but politics and war have not ceased to be vehicles for myth. Instead, primitive versions of religion are replacing the secular faith that has been lost. Apocalyptic religion shapes the policies of American president George W. Bush and his antagonist Mahmoud Ahmadinejad in Iran. Wherever it is happening, the revival of religion is mixed up with political conflicts, including an intensifying struggle over the Earth's shrinking reserves of natural resources; but there can be no doubt that religion is once again a power in its own right. With the death of Utopia, apocalyptic religion has re-emerged, naked and unadorned, as a force in world politics. ${ }^{101}$
\end{abstract}

Elsewhere, Gray asserts: "The mass political movements of the twentieth century were vehicles for myths inherited from religion, and it is no accident that religion is reviving now that these movements have collapsed." ${ }^{102}$ The myth of human meaning, while an illusion, is ineradicable. When the ideology that sustains it becomes implausible it is resurrected in another form and continues to shape human

\footnotetext{
100 Gray, Gray's Anatomy: Selected Writings, 297.

101 Gray, Black Mass, 4.

102 Gray, Gray's Anatomy: Selected Writings, 293.
} 
politics and self-understanding. As such, this illusion is intrinsic to human nature; as Gray himself insists, we cannot live without it.

Gray concludes that we must learn to live with this myth, this illusion. If its denial only results in its re-emergence in degraded form, then the only option is to embrace it. Consequently, he concludes Black Mass by opining: "The most necessary task of the present time is to accept the irreducible reality of religion ... religions express human needs that no change in society can remove - for example the need to accept what cannot be remedied and find meaning in the chances of life. Human beings will no more cease to be religious than they will stop being sexual, playful or violent."103

For Gray, the ubiquity of religious myths is a constant which must be harnessed for its potential in helping us deal with the contingencies and conflicts of our existence, since "at its best religion has been an attempt to deal with the mystery rather than the hope that mystery will be unveiled."104 In the latter part of this thesis, the power of Christian 'myth' to make sense of our pluralist existence in a non-violent way will be explored as a counter-proposal to Gray's bleak prognostication that "the violence of faith looks set to shape the coming century." 105

\section{MOdUS VIVENDI}

\footnotetext{
103 Gray, Black Mass, 293-4.

104 Ibid., 297.

105 Ibid.
} 
Gray's constructive proposal for politics is that it must take the form of a modus vivendi; a political regime that aims to resolve conflicts between differing and diverse groups without privileging a particular view of the good, or any one set of values. Gray describes a modus vivendi as the kind of political project that best represents the liberal ideal of toleration, without seeking an "ultimate convergence on values."106 He writes:

\begin{abstract}
Liberalism contains two philosophies. In one, toleration is justified as a means to truth. In this view, toleration is an instrument of rational consensus, and a diversity of ways of life is endured in the faith that it is destined to disappear. In the other, toleration is valued as a condition of peace, and divergent ways of living are welcomed as marks of diversity in the good life. The first conception supports an ideal of ultimate convergence on values, the latter an ideal of modus vivendi. Liberalism's future lies in turning its face away from the ideal of rational consensus and looking instead to modus vivendi. ${ }^{107}$
\end{abstract}

Modus vivendi is, for Gray, the only conceivable political project that does not privilege a particular set of values as the ideal for society or as the telos of which every form of society is an approximation. Rather, in making toleration and peaceful coexistence its goal, modus vivendi allows various views of the good life to coexist without requiring conformity to any one view.

Gray recognizes that a consequence of his values pluralism is the admission that not all legitimate regimes need be liberal. That is, there are many forms of "the good life" that can be protected and embodied by political regimes that do not hold

\footnotetext{
106 Gray, Two Faces of Liberalism, 105.

107 Ibid.
} 
to traditionally liberal values. "There are minimal standards of decency and legitimacy that apply to all contemporary regimes," writes Gray, "but they are not liberal values writ large.... A regime can be highly legitimate without honouring values that are distinctly liberal." ${ }^{108}$ From as early on as his book Liberalisms, written in 1989, Gray has asserted: "If we abandon the delusive perspective of universality ... we can see liberal society as a historical achievement, an inheritance of institutions and traditions which informs our thought and practice in profound ways, but which we are bound to acknowledge has no universally apodictic character."109 However, this does not lead Gray to conclude that we abandon Liberalism. Rather, it can be embraced as our historical inheritance, but not as our universal destiny. There is nothing to suppose that liberal democracy is the final form of human flourishing. Rather it is the product of our modern times. Gray writes: "To deny the historical reality of liberal individuality is then absurd, but to turn it into a universal theory - or, after the fashion of the Enlightenment, to appoint it the telos of history is to traffic in illusions." ${ }^{110}$ Gray's suggestion of a politically legitimate regime is one that embraces the historically bound polities that exist, without privileging or enshrining any of them as an ideology.

Gray's suggestion for a modus vivendi is one of limited government with the promotion of peaceful coexistence as its primary function. "The implication of this perspective for the character of the modern state," writes Gray, of his proposal for a

\footnotetext{
108 Ibid., 109-10.

109 Gray, Liberalisms, 240.

110 Gray, Post-Liberalism, 259.
} 
modus vivendi, "is that ... modern government must be limited government. ... The liberty that is preserved is that of the liberal individual, but it is a liberty that thereby guarantees cultural freedom - the condition in which individuals may opt to explore an inherited form of life, or migrate across traditions to a chosen lifestyle, if they so wish." 111 The embracing of cultural diversity is a primary value for this form of government. But its highest value or animating telos is peaceful co-existence. The establishing of this point is of central importance to any analysis of Gray's theory. Given his rejection of the possibility of a legitimate telos for human life and society, it is important to consider his argument for peaceful coexistence as the highest value of his political proposal:

The case for modus vivendi is not that it is some kind of transcendent value which all ways of life are bound to honour. It is that all or nearly all ways of life have interests that make peaceful coexistence worth pursuing. Peaceful coexistence is worth pursuing only insofar as it advances human interests. Like any political ideal, it is a contingent good.

Because they are practised by human beings, all ways of life have some interests in common. As we know, it is frequently those interests that divide us. At the same time they give us reason to pursue coexistence. ${ }^{112}$

While these statements are sufficiently vague as to resist categorical definition, they indicate that Gray posits the existence of a common human interest that suggests peaceful coexistence to be a universal good. While a thorough analysis of the logic and consistency of Gray's position will be undertaken in the following chapter, it is

\footnotetext{
111 Ibid., 265.

112 Gray, Two Faces of Liberalism, 135-6.
} 
enough to note here that his proposal of a modus vivendi privileges the value of peaceful coexistence among a diversity of cultures, and that it does this at the expense of other values (such as liberal values) that would make claims to universality - claims that Gray denies to all values.

Again, in Black Mass, Gray writes of his political proposal, referring specifically to the persistence of diverse religious beliefs:

$$
\begin{aligned}
& \text { It embodies a type of tolerance whose goal is not truth but peace. When the } \\
& \text { goal of tolerance is truth it is a strategy that aims for harmony. It would be } \\
& \text { better to accept that harmony will never be reached. Better yet, give up the } \\
& \text { demand for harmony and welcome the varieties of human experience. The } \\
& \text { modus vivendi between religions that has flourished intermittently in the past } \\
& \text { might then be renewed. }{ }^{113}
\end{aligned}
$$

Here, it seems, Gray privileges peace over truth. If this turns out to be an accurate analysis, then Gray's modus vivendi may have just as little, and as much, of a reasonable foundation as liberal values, anthropocentrism and the belief in a telos, or ultimate good for human life.

\section{SUMMARY}

In Black Mass, John Gray argues that modern politics is utopian; it seeks the creation of an ideal world. This utopianism is unrealizable because of the essential conflictual nature of the human needs, which constitute our human nature. Furthermore, the truth that there is a plurality of values, many of which are incommensurable - that is, they cannot be combined, ranked or rationally chosen

\footnotetext{
113 Gray, Black Mass, 295. Italics mine.
} 
between in many situations - indicates that human life cannot be oriented to a particular telos which is rationally constructed and toward which all human societies converge. This idea undermines the possibility of a valid teleology and thus undermines all utopian projects, since they all seek the telos of a perfect society.

Gray argues that Christian theology is the source of modern teleology. Secular political philosophy has embraced the notion of a future salvation for humankind, albeit a political one, rather than a divine one. Further, Christianity is also the source of anthropocentricism since it gives ultimate value to persons, as made in the image of God. The combination of anthropocentric thinking and teleology has continued to sustain human belief in the meaningfulness of human life, even in secular society. While the meaningfulness of life is an illusion, it is not one that human beings can live without, for it re-emerges in other forms wherever it is repressed. Hence secular humanism has revived the Christian belief in an ideal telos for human life.

Once it became divorced from a reliance on divine providence, utopian thinking became violent, using terror and violence to bring about the ideal social conditions it sought. The violence of utopianism is underpinned by the illusion that human nature can be transformed through the use of terror, and that the current imperfections of any society are the consequence of flawed systems, rather than an imperfection in human nature itself.

Finally, Gray proposes modus vivendi as a plausible political regime in a pluralist culture. Government should not aim to promote or uphold a particular view of the good, since the good is many and diverse. Rather, it should seek to facilitate 
the peaceful coexistence of diverse groups, providing a forum for political negotiation, rather than the universalization of rights and ways of life that are particular and historically contingent. 


\section{CHAPTER 3: GRAY'S ANATOMY}

\section{A CRITIQUe of JoHn GRAY'S THESIS}

John Gray's critique of Enlightenment thinking and his proposal of a modus vivendi are beset by logical inconsistencies. Gray rejects a very specific and rare form of teleology and supposes that he has thereby defeated every form of it. This is largely due to his limited notion of what a telos must entail. This creates difficulty for Gray's argument by virtue of the fact that his own proposal relies on a species of teleology. In order for Gray's rejection of teleology to remain consistent, he would have to embrace the nihilism that lingers behind his thought and surrender all hope of making any constructive proposals for politics. His refusal to do so reveals his own "faith" in the nature of human life as irresolvably conflictual. This faith (his values pluralism) is at odds with his modus vivendi - a political system that could not exist without dissolving the very conditions that necessitate it. These issues render Gray's argument logically incoherent, for it is yet another faith in a marketplace of faiths, albeit a faith which offers little to human existence. Gray's analysis of eschatology and violence is likewise rendered ineffectual by the inaccurate location of "violence" in the heart of Christian eschatology. Rather, secularism is, like other systems of thought, a rival faith to Christianity, and one that, by virtue of its susceptibility to nationalistic and mundane goals, embraces and perpetuates violence. Despite his attempts to disabuse us of our Christian “illusions", Gray's own thought is unable to define itself apart from those horizons of peace and human flourishing that Christianity bequeathed to the Western world.

In the prologue to his third edition of After Virtue, Alasdair Maclntyre outlines a 
way of critiquing a rival tradition in a way that overcomes the lack of shared presuppositions that often renders inter-tradition critiques ineffectual. In Maclntyre's proposal, a rival tradition must be critiqued internally; that is, the tradition's irrationalities and contradictions must be exposed on its own terms. If one's own tradition is able to reconcile or adequately explain these difficulties, it thereby demonstrates its superiority to that first tradition. Maclntyre explicates the method for someone wanting to critique a rival tradition as follows:

A necessary first step would be for them to come to understand what it is to think in terms prescribed by that particular rival tradition, to learn how to think as if one were a convinced adherent of that rival tradition. ... A second step is to identify, from the standpoint of the adherents of that rival tradition, its crucially important unresolved issues and unsolved problems unresolved and unsolved by the standards of that tradition - which now confront those adherents and to enquire how progress might be made in moving towards their resolution and solution...

When the adherents of a tradition are able through such acts of imagination and questioning to interrogate some particular rival tradition, it is always possible that they may be able to conclude, indeed that they may be compelled to conclude, that it is only from the standpoint of their own tradition that the difficulties of that rival tradition can be adequately understood and overcome. It is only if the central theses of their own tradition are true and its arguments sound, that this rival tradition can be expected to encounter just those difficulties that it has encountered and that its lack of conceptual, normative, and other resources to deal with these difficulties can be explained. So it is possible for one such tradition to defeat another in respect of the adequacy of its claims to truth and to rational justification, even though there are no neutral standards available by appeal 
to which any rational agent whatsoever could determine which tradition is superior to which. ${ }^{1}$

It is this kind of critique I wish to level at Gray's argument. While it does not represent a "tradition" as such, his argument still has inconsistencies and internal contradictions that can be resolved more adequately by reference to theological positions. While I will make a more thorough theological proposal in a later chapter, theological concepts will be developed and employed in this critique to the degree that they are able to resolve those contradictions and difficulties most central to Gray's proposal.

Gray himself endorses this kind of internal or "immanent critique" in his approach to the liberal tradition. He notes that once the pursuit of normative universal values is abandoned (as it is in Gray's theory), a tradition or theory can only be rationally evaluated and reformed according to the values of that self-same tradition or theory. Gray writes:

Once the fundamental liberal project of achieving an Archimedean point of leverage on practice is abandoned, theorizing can turn to the institutions, conventions and traditions that comprise the practice of liberty. Criticism and reform of existing civil societies may then proceed, but it will be immanent criticism, internal to the life of each specific civil society, which does not pretend to be governed by any abstract conception of freedom. ${ }^{2}$

In order to critique Gray's argument, a similar approach will be taken, by which his positions will be critiqued from within. The points of interest, then, will be those

\footnotetext{
${ }^{1}$ Alasdair MacIntyre, After Virtue, Third Edition. (Notre Dame, Indiana: University of Notre Dame Press, 2007), xiii.

2 Gray, Post-Liberalism, 318.
} 
points of inconsistency and unresolved conflict. Of course, this kind of critique can only be mounted on the assumptions and "foundations" of Gray's argument. A separate line of "external" critique will challenge the validity of these assumptions.

\section{An IMMANENT CRITIQUE OF GRAY'S THESIS}

Gray's Teleological "Straw Man"

Gray rejects universal meaning in favour of particularity. Despite his affirmation of "universal human needs," ${ }^{3}$ Gray's account of values pluralism (and the philosophical anthropology that underpins it), locates the source of human values in their social contexts or ways of life. While he accepts that there are universal values, Gray rejects their universalizability across contexts on the grounds that there may be many different ways for these values to be applied, not just one: "If rational inquiry has failed to produce agreement on the best life, it is not because of any imperfection in human reason. It is because the idea of perfection has no sense in human life." The subtlety of this point must not be missed: universal values cannot be normative for Gray. They are universal in the sense they are shared by all, but they cannot then constitute a singular, universal morality, due to their conflicting and incommensurable nature.

On the basis of this account of values-pluralism, Gray rejects teleology and the meaning of human history. ${ }^{5}$ He writes: "On the pluralist view, human history as a

\footnotetext{
3 Gray, Black Mass, 279.

${ }^{4}$ Gray, Two Faces of Liberalism, 39.

5 "Telos" is a Greek word with two meanings: Literally, it means "end" but this can have either a temporal or a logical reference. In philosophy it can have the connotation of "aim" or "ultimate
} 
whole has, and can have, no meaning; it is at best, a series of adventures in civilization, each singular and discrete, leading nowhere, and at no point disclosing or approximating the features of 'man qua man'." In Gray's theory, if there are many views of the good life, there can be no way to judge human history's progress in terms of its approximation to the good, since for Gray, as has been noted in the previous chapter, only one combination of values, normative for all, can be considered a telos.

Gray's conclusion as to the meaninglessness of human history is a false dichotomy. His argument proceeds as follows: (A) For human history to have meaning it must have a single, definable telos; (B) Values pluralism demonstrates that there is not a single telos for human life; therefore, $(C)$ Human history has no meaning. However, it is not clear that $(A)$ is necessarily true. Need human history be rationally inevaluable because there is a plurality of human goods? There is no reason why this should be true. Gray himself acknowledges that there are universal values which can form a "moral minimum" by which regimes can be judged to be more or less legitimate: "no regime can truly claim to embody the best settlement of conflicts among universal values." "But they can still claim to be good ones; they

object" (Oxford Dictionary). While the two connotations are related, they are not identical. Gray rejects both kinds. He rejects the notion of an "end of history"; there is, for him, no ultimate political system toward which all other political systems are heading. However, he also rejects the notion of an "ideal" as well. For Gray, the notion of a perfect combination of values is rendered meaningless by the incommensurabilities of values pluralism. There is no telos of either a historical or theoretical kind. (Black Mass, 6.)

6 Gray, Post-Liberalism, 292.

7 Gray, Two Faces of Liberalism, 67. 
can claim that they are within that group of legitimate regimes that avoids all, or as many as possible of, the generically human evils Gray acknowledges.. ${ }^{8}$ Glen Newey makes this point:

Surely the requirement to avoid these [universal] evils could itself form the basis of such a [minimum] morality, even if there is no universally valid means of choosing between evils? After all, many Kantians argue that reason can generate a universal minimum morality, even if its application remains circumstantially variable. ${ }^{9}$

The teleological view of history that Gray rejects is a "straw man". The key to Gray's logical error is made clear in the details of his argument, in Post-Liberalism, where he writes:

True, there may be improvement within any particular culture, as judged by its own standards; and there may, as limiting cases, be a few instances, in which we can judge that, granted all relevant incommensurabilities, there has been a betterment or a worsening in goods and evils that are not culture-specific, but generically human. This latter limiting case gives no support, however, to the whiggish conception of history as a narrative of progress, as a moral drama with ourselves as its telos, which is one of the many illegitimate offspring of Judaeo-Christianity that inform the sentimental and absurd religion of humanity which is the secular faith of the Western intelligentsia. On the pluralist view, human history as a whole has, and can have, no meaning. ${ }^{10}$

\footnotetext{
8 Ibid., 66.

9 Glen Newey, "Gray's Blues: Pessimism as a Political Project," in The Political Theory of John Gray (London: Routledge, 2007), 276.

10 Gray, Post-Liberalism, 292.
} 
Given the complexity of his sentences, it may be helpful to isolate the specific claims made here by Gray. The first (made just before this excerpt, and at its conclusion), is that human history has no meaning, no sense of progressing or improving. However, just after admitting that there are examples of "a betterment or a worsening in goods and evils that are not culture-specific, but generically human," Gray then goes on to assert, despite the fact that such an admission supports the notion of "progress" in general, that this "gives no support" to "the whiggish conception of history as a narrative of progress, as a moral drama with ourselves as its telos" - which is a definition of the idea of meaning in human history in narrow and easily contestable terms. Gray then concludes, as if this has demonstrated his point clearly, that "human history...can have no meaning." Even forgetting the fact that Gray is making an argument from absence (also a false dichotomy), he is attacking a straw man. Certainly there are some who regard our current civilisation as the highest achievement of history, like Fukuyama, whom Gray dismisses; ${ }^{11}$ but many who adhere to a progressive or Enlightenment view of history, would merely assert that what we have now is better than much of what has preceded, without wanting to claim that we are at history's end or goal. This is one example of the false either/or dichotomies that Gray's argument stands or falls on. Marcus Roberts, in his response to Enlightenment's Wake, makes the same point:

[T]he abandonment of "the Enlightenment conception of the historical progress of the species" does not follow from value incommensurability unless all that is meant by "the Enlightenment conception" is crude

\footnotetext{
${ }^{11}$ See, for example, Black Mass, p.173 where Fukuyama's thought is classified as "a mix of crackpot realism and chiliastic fantasy."
} 
teleologism combined with utopian visions of an absolutely marvellous society, successfully reconciling, once and forever, all good things. But in that case it is one to which few of those Gray is attacking are committed. ${ }^{12}$

Likewise, Gregory Johnson contends: "the most plausible construal of Gray's position makes his opponent look like a straw man."13 There is no reason why history cannot be viewed as potentially progressive, and actually so in many cases. If there are universal goods and evils, as Gray accepts, then any regime may be assessed by reference to these. While Gray is correct in saying there is no one best way to combine these often incommensurable, universal values - which Gray construes as evidence of the "abundance of good lives that human beings can live"14 - he is wrong to say that this then means no objective judgements can be made. Only regarding the one best system of government can there be no judgement made. The judgement that governments are better or worse is not excluded by such a conclusion. Rather, what Gray rejects is an ontology where "truth" is singular.

Inherent in Gray's argument, then, is the fundamental tension in philosophy between the One and the Many. Gray rejects the universalising of the One at the expense of the Many, yet his proposal (as any political proposal must be) is an attempt to make the Many, One, without it being dissolved into sameness. In his discussion of the pre-Socratic philosopher Thales, Frederick Copleston identifies the genesis of the philosophical idea of "the One and the Many":

\footnotetext{
12 Marcus Roberts, "The Endurance of History? Reflections on John Gray's Post-Enlightenment Pluralism," Res Publica 3, no. 2 (1997): 202.

13 Gregory Johnson, "The Non - Sequitur of Value Relativism: A Critique of John Gray's 'Post-Liberalism',' Reason Papers, no. 19 (Fall 1994): 102.

14 Gray, Two Faces of Liberalism, 68.
} 
[Thales] earns his place as the First Greek philosopher from the fact that he first conceives the notion of Unity in Difference ... and, while holding fast to the idea of unity, endeavours to account for the evident diversity of the many. Philosophy naturally tries to understand the plurality that we experience, its existence and nature, and to understand in this connection means, for the philosopher, to discover an underlying unity or first principle. ${ }^{15}$

Gray is not therefore discovering some new fact about the world in his presentation of values pluralism and modus vivendi. Rather, his is an attempt at re-solving a tension inherent in the way that humanity has apprehended reality from the earliest times. In a prescient statement (given Gray's own treatment of this problem), indicating his own Thomist loyalties, Copleston suggests the kind of thought which best resolves this paradox, and the likely outcome when these ideas are not present: Justice can be done to the complexity of the problem of the One and the Many only if the essential degrees of reality and the doctrine of the analogy of being are clearly understood and unambiguously maintained: otherwise the richness of the manifold will be sacrificed to a false and more or less arbitrarily conceived unity. ${ }^{16}$

It is against just this kind of "arbitrarily conceived unity" that Gray sustains his critique of Liberalism and the Enlightenment project. It is a strength of Gray's that he discerns a weakness in Liberalism's resolution of this perennial tension. However, his own unifying proposal is "more or less arbitrarily conceived" in that it is founded on relatively unexamined and relatively unjustified presuppositions, as will be demonstrated below. It is important to note, however, that it is not the fact of having presuppositions for which I criticize Gray; rather, it is their unexamined and poorly

\footnotetext{
15 Frederick Copleston, A History of Philosophy, vol. 1 (New York: First Image Books, 1994), 23. 16 Ibid.
} 
justified nature. Their "unexamined" nature becomes clear when it can be demonstrated how they are inconsistent with the rest of his thought.

\section{THE INHERENT TELEOLOGY IN GRAY'S MODUS VIVENDI}

Gray undermines the claim that human history is without meaning when he suggests a modus vivendi as a "better" regime than others. As has been noted, the idea of meaning requires a goal or telos that human life can be judged as being either closer to or further away from; hence meaning requires the possibility of "progress" which Gray rejects. He insists that "value-pluralism as a theory of ethics points towards modus vivendi as a political ideal." ${ }^{\text {"17 }}$ If all regimes are judged as "leading nowhere, and at no point disclosing or approximating the features of 'man qua man'"'18, then how can modus vivendi be an ideal? In Gray's view, it is an ideal because it more accurately approximates the features of the indeterminacy of human nature; the fact of values-pluralism is better represented by modus vivendi, according to Gray's argument. Surely, then, this is an example of that "'general, progressive amelioration of the world"” that Gray regards as "'a fiction'". ${ }^{19}$ If Gray suggests that modus vivendi should replace Liberalism, the implicit rationale is that it is because it is an improvement; in some objective way it is better than Liberalism. Again, Newey is insightful in indicating the subtlety in this truth:

What is up for grabs in politics is, for the pessimist [such as Gray], the sub-ideal as opposed to something still worse. Hence it is the prime role of politics to secure what is securable - which, compared with some worse

\footnotetext{
17 Gray, Two Faces of Liberalism, 68.

18 Gray, Post-Liberalism, 292.

19 Ibid. This is Gray quoting (and approving of) Herder.
} 
outcomes, may be quite a lot. The best may be the enemy of the good, as the saying goes, but the bearably bad can also be made the enemy of the worst. $^{20}$

If this is not progress, then it is not so only in terms of Gray's narrow definition whereby the "best" is identical to the perfect or ideal. Progress can be of this more modest species, and it is this kind of progress that Gray's own proposal admits.

What is problematic for Gray's argument is that his rejection of teleology is inconsistent. Not only does Gray fail to see the potential for the coexistence of a telos and a plurality of ways of life, he also fails to see the telos in his own proposal of a modus vivendi. As Crowder has demonstrated, it "amounts precisely to the kind of universal privileging of a particular notion of the good that he attributes to liberal universalists." 21 His proposal of a modus vivendi privileges the value of toleration and its concomitant telos of peaceful coexistence. Horton defends Gray's account of modus vivendi against this charge, highlighting that Gray "need not claim that modus vivendi is the supreme good; only that if people want to live together in a civil manner, without resort to tyranny or persistent violent struggle, and in a way that at least extends a measure of toleration to diverse ways of life, then modus vivendi is the best way forward."22 If this is all that Gray is claiming, then his claim for a modus vivendi is only that it is, like Liberalism, legitimate to the degree that it embodies the values of those who subscribe to it. And these values would be those of peaceful

\footnotetext{
20 Newey, “Gray's Blues: Pessimism as a Political Project," 281.

${ }^{21}$ George Crowder, Liberalism and Value Pluralism (New York: Continuum International Publishing Group, 2002), 121.

22 John Horton, "John Gray and the Political Theory of Modus Vivendi," in The Political Theory of John Gray (London: Routledge, 2007), 55.
} 
coexistence and toleration. However, where these values are not shared, Gray's proposal ceases to be of value. The paradox inherent in this position will be addressed shortly.

\section{GRAY'S PRIVILEGED VALUES}

It is not clear, however, that this is all that Gray claims for his modus vivendi. When he writes that "Modus vivendi continues the liberal search for peaceful coexistence; but it does so by giving up the belief that one way of life, or a single type of regime, could be best for all", ${ }^{23}$ it is apparent that he assumes that peaceful coexistence above all else is best for all. Crowder maintains that this is as universalist as the liberal universalism Gray critiques:

How is Gray's position any different from the liberal universalism he condemns, other than in the content he gives to his privileged values? While Gray accuses the liberals of promoting their values of individual liberty, toleration and so forth over others, liberals could retort that Gray merely substitutes for liberal concerns a doctrine of self-interest or of peace at any price." 24

Peter Lassman makes a similar observation:

In effect, Gray smuggles in through the back door the considerations that he found so objectionable in other forms of liberalism, including those clearly belonging to the Enlightenment tradition...Gray makes the value of respect for other ways of life central for the stability of his version of modus vivendi. $\mathrm{He}$ is also assuming that rational citizens of a regime of modus vivendi would prefer compromise to conflict. It is hard to see here where the clear

\footnotetext{
${ }^{23}$ Gray, Two Faces of Liberalism, 139.

24 George Crowder, "Gray and the Politics of Pluralism," in The Political Theory of John Gray (London: Routledge, 2007), 66.
} 
difference exists between Gray's modus vivendi and some of the versions of liberalism that he wants to reject. ${ }^{25}$

Gray's proposal excludes the possible goods of ways of life that wish to privilege as universally normative the value of "purity" or "obedience to God's decree" above peaceful coexistence, as for example, Islamic Sharia law does. Or in a less extreme case, it excludes the possible goods of ways of life that value the universal responsibility of the rich for the poor. Certainly there is a case for modus vivendi in a shared culture where all value peaceful coexistence and share Gray's values-pluralism. But this possibility raises two serious objections to Gray's proposal.

First, in any society where people hold to the notion of universal values, in order to adopt a modus vivendi, they would be required to submit to a system that negated in theory, and in practice, their values. How this is any less hegemonic than liberalism, or any other political theory that comes under Gray's criticism, is unclear. It precludes the beliefs of any of religious faith, any who are liberal universalists, and in fact any who believe in the application of any universal value. They will only be able to participate in a modus vivendi to the extent that they can accept a values pluralist reading of society, hence renouncing their universal values..

The second, related criticism is a pragmatic one raised by Roberts. It highlights what Gray himself admits - that human beings cannot live without the illusion (if that is what it is) of meaning, and hence of the universality of their beliefs.

\footnotetext{
25 Peter Lassman, “Pluralism and its Discontents: John Gray's Counter-Enlightenment.," in The Political Theory of John Gray (London: Routledge, 2007), 111-2.
} 
Roberts writes:

Indeed, whereas Gray argues for the pursuit of a modus vivendi via processes of bargaining, negotiation and compromise, the rival traditions he is seeking to reconcile are defined largely, and precisely, by those principles they take to be non-negotiable, not to be bargained over, not up for compromise. The idea that conservative Catholics and secular liberals, for example, might compromise over abortion is simply absurd. ${ }^{26}$

Roberts' point is a good one; that in order to accept the premises of a modus vivendi, the very conflicts that require one for their resolution are eradicated. In his own words:

If the argument for the pursuit of a modus vivendi (i.e., for value pluralism) is conceded, then the conflicts that necessitate such a pursuit may cease to arise; yet, conversely, so long as there is conflict between traditions claiming an "historically privileged status" for their own values -- a claim, Gray now admits, which may be required for the reproduction of those traditions -- no modus vivendi will be achievable (if this means anything other than an armed truce, and perhaps not even then). ${ }^{27}$

A true modus vivendi, then, may be an illusory phantom. Caught between the horns of the necessity of conflictual ways of life to justify its existence, and the subsequent requirement to surrender the universalist positions that underpin these ways of life in order to participate in it, modus vivendi appears to be an unworkable model for any actual society.

\section{Resolving the Contradictions: Contingent Teleology or NiHILISM}

\footnotetext{
${ }^{26}$ Roberts, "The Endurance of History? Reflections on John Gray's Post-Enlightenment Pluralism," 207.

27 Ibid., 206-7.
} 
A possible resolution to these difficulties in Gray's argument would entail, not the rejection of teleology, but the proposal of a contingent teleology. Without shared ways of life across human cultures, an orientation toward peaceful coexistence is without foundation. There is no reason that stands apart from shared ways of life that necessitates the pursuit of a modus vivendi. If there is a shared reason to value this as a telos, then Gray undermines his own argument that there are no universal human values. Gray tries to let such a shared value in through the back door by asserting the need for peaceful coexistence as an answer to universal human needs. But human needs are merely the negative form of values. If the need for security and peaceful coexistence is essential, which Gray's proposal implies it is, then these needs can be presented as the valuing of peaceful coexistence and the proposal of a telos of peaceful coexistence (or a modus vivendi). That this modus vivendi embraces and is contingent on the imperfectability of human existence does nothing to invalidate it as a telos, of the kind described above. Regardless of its realisability, in whole or in part, it is inconsistent with Gray's rejection of teleology. Therefore the most Gray can reasonably do is reject a certain kind of teleology - the perfectible kind - and embrace a contingent teleology: one that is modified by the imperfection of human existence. It is only a contingent teleology of this kind that can embrace both the particularity of human life and the orientation toward a universal telos that even Gray is unable to remove from his thinking.

It is precisely this type of contingent teleology that Christian faith embraces. As Gray has acknowledged, Christianity, with its belief in divine "providence", does 
not seek to achieve its telos solely by human agency. ${ }^{28}$ Furthermore, its realism about human fallibility gives Christianity the resources to embrace imperfection without relinquishing teleology. Gray's rejection of a perfectible teleology leaves him with the choice of either embracing a contingent teleology, or of rejecting his proposal of modus vivendi in favour of nihilism.

If Gray rejects teleology in toto, the only option left to him is nihilism, and the rejection of any normative proposals for politics. If there is no telos - no goal, regardless of how many and varied its incarnations - then there can be no meaning for human life as progress. Gray is correct on that account; teleology and meaning go together. But a true rejection of these leaves no room for proposals of any kind. Newey makes this observation of Gray's thought:

His naturalism suggests that human striving is futile, while his nihilism about human values doubts whether there is anything of worth for humans to strive for anyway. Gray's devaluation of all values and insistence on the vanity of action spell the death of politics, both in theory and practice. ${ }^{29}$

If there is no telos for humankind, there can be no normative values - only radically chosen values. And choosing the values of violence and anarchy would be no less valid than choosing peaceful coexistence. These values are, in Gray's scheme, incommensurable. To judge between them would require them to submit to some ultimate value (like the value of human life, for example). And it is clear, even from this brief analysis, that one can keep trying to ground values endlessly, and

\footnotetext{
28 Gray, Black Mass, 39.

29 Newey, “Gray's Blues: Pessimism as a Political Project," 276.
} 
hopelessly, when the belief in normative, universal values is surrendered. Although Gray and many other secular philosophers would like to remove belief from their arguments, it actually lies at the foundation of every constructive proposal - even (as will be demonstrated next) Gray's.

\section{GRAY'S FAITH}

Gray's argument, while disparaging Enlightenment "faith" in progress, preaches it own article of faith: the irreducible diversity of human values. Gray's values pluralism is founded on a particular reading of the world: one that privileges the normative value of diversity. Johnson makes this point well when he writes:

Gray, however, simply assumes that the plurality of values is "irreducible." This implies, a fortiori, that it is irreducible by rational criticism and discussion. It implies that there is nothing that we can say about any particular value to recommend that it be adopted to the exclusion of other, incompatible values - nothing, save our arbitrary choice to value it, take it or leave it. Values, in short, are personal, idiosyncratic, not publicly-justifiable. ${ }^{30}$

Gray's position as a values-pluralist is no more rationally defensible than the "myth of progress" which he rejects. As Johnson explains, it simply does not follow that the existence of plural values in any way proves that this plurality is irreducible or normative. For Gray to privilege his values pluralism is no less of a mythologizing than the "Enlightenment faith in progress". Glyn Morgan writes:

But if Gray's argument for a modus vivendi depends upon a wide public acceptance of this form of multiculturalism then Gray's modus vivendi rests

\footnotetext{
30 Johnson, "The Non - Sequitur of Value Relativism: A Critique of John Gray's 'Post-Liberalism'," 103-4.
} 
upon foundations no less controversial, no less sectarian, than the substantive form of liberalism that he is so eager to dispatch. Indeed, Gray's argument for a modus vivendi polity involves the abandonment of a 'myth' of progress in favour of a 'myth' of diversity."31

The reliance of values pluralism on the foundational "myth" of diversity undermines Gray's claim that values pluralism is distinct from relativism. If Gray's claim regarding the irreducible plurality of values is a foundationalist one, then values pluralism cannot claim to be anything other than the assertion that all values are of equal standing and therefore relative. Gregory Johnson, in analysing Isaiah Berlin's value pluralism - which is the source of Gray's conception - demonstrates that Berlin's account fails to maintain the objectivity of values, and thus plunges his values pluralism into relativism. This devastating critique cuts to the very heart of Gray's argument, and will be quoted at length:

Berlin's first claim - that objective values can be publicly understood but subjective values cannot - seems to miss the point of the objection against him. Above I claimed that Berlin and Gray are value relativists and subjectivists because they hold that the multiplicity of conflicting values is in principle irreducible. To claim that the multiplicity of values is irreducible in principle implies, a fortiori, that it is not reducible through rational investigation and argumentation. It means that there is nothing about any particular value that can recommend its adoption to the exclusion of another, incompatible value. This amounts to saying that all values are equally groundless. The issue, then, is not whether values can be publicly understood, but whether they can be publicly justified. Berlin is a relativist

\footnotetext{
31 Glyn Morgan, "Gray's Elegy for Progress," in The Political Theory of John Gray (London:
} Routledge, 2007), 125. 
not because he claims that values are not publicly intelligible - which he does not - but because he claims that they are not publicly justifiable. ${ }^{32}$

If there is no common ground for the justification of one set of values over another, then these values are more than incommensurable, they are also relative - relative to the ways of life from which they spring.

Gray's defence of values pluralism against the charge of relativism requires some careful analysis. Gray grounds the source of values in "ways of life" so that when different ways of life come into contact with each other, they often will not have the shared presuppositions needed in order to decide between their values. ${ }^{33}$ If this were all that Gray argued, then the charge of relativism would be straightforward, given that no rational grounds could be made to argue for these values. In the absence of any rational argument for the preferring of one value over another, values from differing ways of life are deemed "relative". Gray characterises this objection as follows:

The assumption underlying it is that if values are incommensurate they must belong to forms of life that have no categories or concepts in common. If this is so, judgments deploying values that are incommensurable cannot be mutually translatable. They are bound to be mutually unintelligible. ${ }^{34}$

In response to this Gray asserts that people are not "radically situated subjects, embedded once and for all in a single way of life. Nearly all of us belong in several

\footnotetext{
32 Johnson, "The Non - Sequitur of Value Relativism: A Critique of John Gray's 'Post-Liberalism'," 106.

33 Gray, Two Faces of Liberalism, 52.

34 Ibid., 51.
} 
ways of life." 35 The fact that we can participate in different ways of life and still decide between values from these opposing (in Gray's words "incommensurable") ways of life, confirms the fact that these values can be evaluated rationally, hence they are not relative, but incommensurable; they can be decided between, but not in one best way that privileges one over the other.

Gray's error in this argument is that he has assumed that ways of life, and the values they promote, are irresistibly normative for an individual. He assumes that, when one is faced with the competing claims of loyalty to a friend and the claims of honouring a contractual agreement (to use Gray's example, cited in the first chapter), ${ }^{36}$ there is no reasonable way to resolve this conflict that is right for every person. Nonetheless a decision can still be made between them based on the context and history of the individual who makes the decision. Gray's mistake here is in assuming that the values of loyalty and honour are given the same weight in an individual's thinking, as if they emerged out of two rival ways of life that have equal and incommensurable claims on that individual. However, this is an inaccurate account of human rationality. For the individual concerned, these values no longer belong to "rival ways of life", and the individual is not torn between them, like some chameleon that cannot choose which of two backgrounds to assume the colour of. Individuals conceive of themselves and their lives as a unity, and as Gray recognises, they will make a rational choice between values based on their own ranking of values. But "loyalty" and "honour" get their relative "value" in the individual's life

\footnotetext{
35 Ibid., 52.

36 Gray, Black Mass, 42-3.
} 
from the role they play in the individual's own telos or conception of "the good life" for themselves. If "the good life" consists chiefly in good relationships, then loyalty trumps honour. Conversely, if it consists chiefly in respect and business prowess, then honour will trump loyalty. What Gray's simplistic account of the relationship of human life to values overlooks is the necessary connection between values and a telos, or a conception of the good. Where individuals do not share a similar view of the good, they do not share the same system of values. A plurality of values reduces to a plurality of teloi. When values lack a shared telos, they lack the one thing that enables their "value" to be reasoned about, and hence their relationship to each other is one of being relative. ${ }^{37}$

Finally, Newey lays the same charge against values-pluralism, from a macroscopic perspective. In his critique of Gray, he demonstrates the essential logical inconsistency within the values pluralist position:

As Gray argues, values-pluralism is not to be confused with relativism. But if so, some political orders may surely be better than others at accommodating value-pluralism (though Gray rejects the claim that liberalism itself is such an order). It only seems to follow that no single regime is best at accommodating value-pluralism if each possible political order embodies a set of values, and value-incommensurability means that reason cannot

\footnotetext{
37 This is the position of MacIntyre, After Virtue. He argues that all moral arguments in the modern era are interminable and are ultimately expressions of Emotivism. Without a shared telos, moral arguments lack the context that gives meaning to values. While Gray engages briefly with Maclntyre in Enlightenment's Wake (220-28), and substantively concurs with his analysis of modernity and the Enlightenment project, he never considers the ramifications of MacIntyres description of values for his own values pluralism. It appears he regards Maclntyre as being in agreement with him, whereas Maclntyre's argument precludes the acceptance of values pluralism.
} 
decide which set is best. But then we seem to be left with relativism after all. $^{38}$

While this kind of argument appears circular - some polities will embody values pluralism in better ways than others, yet no set of values can be reasonably argued to be better than others - it demonstrates the key philosophical difficulty with values pluralism: it tries to argue for its own position as being most true while simultaneously claiming there is no singularly true position. Gray argues that values pluralism is a truth about our world, as well as arguing that it reveals there is no singular truth about our world. Like every other truth claim, Gray's claim for values pluralism takes its stand within its own presuppositions about the nature of the world. But if values pluralism is nothing more than the privileging of particular presuppositions about the nature of values, presuppositions that are inconsistent with Gray's own claims to objectivity, then the very foundations of his argument have been eroded. Gray seeks to find an objective place to ground his modus vivendi through values pluralism, but in its grounding on the "myth of diversity" it is revealed to be as subjective, as much a "faith", as any other perspective which Gray seeks to critique.

Gray's own dependence on a faith position, despite his criticism of such positions, suggests that all arguments are ultimately grounded on belief - or else they are grounded on nothing. In critiquing Liberalism, and in proposing a modus vivendi as a "better" political proposal, Gray has been seeking to position himself in a more objective or truthful place than that of Liberalism. Curiously, Gray has

\footnotetext{
38 Newey, "Gray's Blues: Pessimism as a Political Project," 162.
} 
conceded the fruitlessness of the search for such an objective place to stand. In Enlightenment's Wake, referring to Neitzsche's commentary on modernity, he writes: "...the upshot of the Neitzschean critique is that all valuation is perspectival. There is no view from nowhere which is 'the moral point of view'; there are only diverse moralities and value-perspectives." ${ }^{39}$ It is ironic, then, that Gray, in grounding his modus vivendi in values pluralism and the "myth of diversity", considers himself to have made a compelling rational argument that "Modus vivendi continues the liberal search for peaceful coexistence; but it does so by giving up the belief that one way of life, or a single type of regime, could be best for all." ${ }^{40}$ In saying this, Gray has only confirmed the truth of his argument that all values spring from, and are limited by, their contexts.

Gray's argument then demonstrates the validity of Maclntyre's analysis of modernity. In After Virtue Maclntyre argues that the modern person still retains the vestiges of pre-modern morality - a morality that was underpinned by a shared way of life, with shared values and a shared telos. Modern moral disagreements are so intractable because they no longer have these shared moral foundations within which to conduct rational debate. Our modern moral perspective is one that Maclntyre labels "emotivism": the expression of subjective preference, which can have no rational basis. On this point, Gray and Maclntyre are in agreement; there are no rational resolutions to many of our modern moral debates. However, Maclntyre

\footnotetext{
39 Gray, Enlightenment's Wake, 162. Gray cites Nietzsche's The Genealogy of Morals as the source of this perspective.

40 Gray, Two Faces of Liberalism, 139.
} 
attributes these intractable moral conflicts to a loss of that shared telos that once unified our common moral life. Gray, by contrast, sees moral conflict as a fundamental characteristic of reality. Whether or not reality is teleological is a matter of bare assertion - it is a foundationalist claim. Gray's assertion that reality is irreducibly plural and therefore without a telos is as much a foundationalist claim, as much an article of faith, as any other claim to meaning or teleology. Gray's exclusion of meaning from human existence is made without sufficient recourse to any rational arguments. The presence or absence of a meaning for human life can only be affirmed or denied, as an article of faith. Gray denies it, assuming that chaos is more fundamental than meaning. But there is no rational reason why the alternative assumption should not be made.

It is true, as Gray recognises, that there can be no solely rational argument for ultimate values. But that does not mean that ultimate values don't exist; it only means that they don't exist for those who rely solely on rationality. To seek to understand human existence in purely rational terms is to reduce the nature of human being. Humans are more than rational animals. Gray asserts meaninglessness and chaos, not for rational or empirical reasons but as an act of faith in the nothingness, in the nihil. The only alternative to nihilism is faith in order and meaningfulness (and perhaps also in some form of deity as their source). The fact that human beings cannot seem to live without a sense of order and meaning tells in favour of such faith, unless, as Gray believes, such a need rests on an illusion.

This concludes the immanent critique of Gray's position. His argument is weakened considerably by the logical inconsistencies. He tries to claim a limited 
scope of meaning for human life: one that rejects the notion of progress but is still able to support the flourishing of human life for no other reason than its own flourishing. Of course, these are ultimate questions and perhaps not ones that can be resolved rationally. However, by the rules he has chosen to play by, much of what he wishes to say is excluded. In particular, he has failed to notice the dependence of all rational thought on non-rational presuppositions, making him oblivious to the faith-like quality of his own stance. We now turn from the internal coherence of Gray's argument to the external claims he makes regarding Christianity and violence.

\section{CHRISTIANITY AND VIOLENCE}

The relationship between religion and violence is central to the thesis of Black Mass, and it is a relationship that is not as straightforward as it at first appears. The first sentence of the book is the key to understanding Gray's argument: "Modern politics is a chapter in the history of religion." 41 Gray goes on to argue, not that religion is violent, but that modern politics is violent because of its religious origins. While Gray traces utopian thinking to a secularised eschatology, it is precisely in the secularisation of these Christian hopes that they become violent. Gray writes:

Post-millenialist Christians propagated beliefs that mutated into the secular faith in progress; but so long as history was believed to be governed by providence there was no attempt to direct it by violence... The decline of Christianity and the rise of revolutionary utopianism go together. ${ }^{42}$

\footnotetext{
41 Gray, Black Mass, 1.

42 Ibid., 39.
} 
Christianity is implicated as a source of modern violence through the secularisation of its hopes. But Christianity itself is not inherently violent, Gray concedes; it is the mutation of Christianity in modern politics that is violent.

Gray does lay blame on Christianity for introducing these hopes to humanity, however. He argues that before Christianity introduced a teleological outlook to the world, Enlightenment thinking and the political violence that has accompanied it were not possible. "Christianity injected eschatology into the heart of western civilization," ${ }^{43}$ writes Gray. He also asserts: "Most religions lack any conception of history as a story with a beginning and an end...Ancient Judaism contained nothing resembling the idea that the world was about to come to an end." ${ }^{\prime 4}$ On this point, Gray is patently wrong. Recent Christian scholarship has contextualised Jesus' message and mission squarely within Jewish apocalyptic hopes of an imminent judgement, "The Day of the Lord", when God would end the present order and establish a new, just order. New Testament scholar N.T. Wright notes that:

[M]onotheism and election, committed any Jew who thought about it for a moment to a further belief: $\mathrm{YHWH}$, as the creator and covenant god, was irrevocably committed to further action of some sort in history, which would bring about the end of Israel's desolation and the vindication of his true people. Monotheism and election lead to eschatology, and eschatology means the renewal of the covenant. ${ }^{45}$

It is a commonplace in New Testament scholarship to identify the aims and

\footnotetext{
43 Ibid., 16.

${ }^{44}$ Ibid., 6.

45 N.T. Wright, The New Testament and the People of God, vol. 1, Christian Origins and the Question of God (London: SPCK, 1992), 247.
} 
eschatology of Christianity as springing from, and standing in continuity with, the aims and eschatology of early Judaism.

More comprehensively, in his Atheist Delusions, David Bentley-Hart makes a particularly devastating and insightful critique of exactly this species of argument which Gray invokes. It merits quoting at length:

One does occasionally hear it argued, I should note, that the great utopian projects of the twentieth century were not, in fact, genuinely secular movements, but, rather, misplaced messianisms, and as such should be seen as only the delayed aftereffects of the old arrangement. On this telling, Christianity - with its promise of a future Kingdom of God - planted a kind of persistent hope in Western culture that, once robbed of its supernatural trappings, naturally mutated into a demonic rage to establish heaven on earth, through a great process of election and dereliction, culminating in historical fires of judgement ... But, really, one should not take these sorts of speculation too seriously. Long before the rise of Christianity, the great empires of antiquity - Egyptian, Persian, Chinese, Roman, and so forth - all claimed a sacred mission and a divine warrant for their conquests, plunders, enslavements, and murders. Temporal power will kill when it chooses to do so, according to its interests and desires, and will employ whatever mythic or ideological instruments lie ready to hand to advance its aims. That Jewish and Christian apocalyptic motifs can be vaguely discerned in the grotesque tapestries of twentieth century ideology is hardly any indication of causal order...Since the one explicit and inviolable rule that has always governed Christian eschatology is that God's Kingdom is not of this world and comes only at God's bidding ... and since, for just this reason, Christian culture never produced any movement of salvation through political action, it is only to the degree that eschatological rhetoric is entirely alienated from any traditional Christian context that it can be exploited for a political project of human redemption. But this is only to reiterate that, in the end, it is the process of secularization itself - and not those elements of the "religious" grammars of the past that the secular order might have misappropriated for 
its purposes - that is the chief cause of the modern state's curious talent for mass murder. ${ }^{46}$

Bentley-Hart agrees it is secularization that has bred violence, but more accurately than Gray he describes the "religious grammar" of Christian eschatology as a tool which secularisation has appropriated in service of its own aims, rather than it having caused modern political violence. Christian eschatology is not intrinsically violent. Gray himself recognises violence is a peculiarly human trait, and he acknowledges that human beings are "a highly inventive species that is also one of the most predatory and destructive." ${ }^{\prime 47}$ Gray is correct that secularism is the source of modern political violence, not because of some specifically Christian inheritance but because it has an agenda of its own, one that has resulted in the unprecedented violence of the modern era.

The thesis that secularism is inherently violent is advanced further by theologian William Cavanaugh. In The Myth of Religious Violence, Cavanaugh examines the common claim that religion is inherently violent. He argues that by defining religion in particular ways, and by reading history with a bias against religion, secular historians and political thinkers have presented Western history (and in particular the "Thirty Years War" following the Reformation) as being riddled with religious violence. This particular reading, Cavanaugh points out, is used to establish the modernist assertion that it is only the secular nation state that has any legitimate right to use violence. After a detailed analysis of the "wars of religion", Cavanaugh

\footnotetext{
46 David Bentley-Hart, Atheist Delusions: The Christian Revolution and Its Fashionable Enemies (New Haven: Yale University Press, 2009), 223-4.

47 Gray, Straw Dogs, 4.
} 
comes to the following conclusions:

We must conclude that the myth of the wars of religion is finally incredible, which is to say, false. A significant proportion of the violence was between members of the same church, and members of different churches often collaborated...It is impossible to separate religious motives from political, economic and social causes...And the idea that the advent of the state solved the violence ignores abundant evidence that state building was perhaps the most significant cause of the violence. ${ }^{48}$

Secularism's claim to neutrality amidst religious tensions is a myth that serves to legitimate the ideology of the modern state and its own (often violent) purposes.

Cavanaugh explicates this thesis with great clarity:

My hypothesis is that the myth of the wars of religion - like the larger myth of religious violence - has been useful for the promotion of Western secular forms of governance as essentially peace making. According to the myth, only by carefully separating the dangerous impulses of religion from the mundane affairs of politics - as the liberal state has done - can a peaceful and prosperous world be finally achieved. In domestic politics, the myth serves both to legitimate devotion to the nation-state and to marginalize actors labelled religious from the public square. In foreign affairs, the myth serves to justify efforts to promote and propagate Western forms of governance in the non-Western world, by violence if necessary. ${ }^{49}$

The myth of religious violence is used to support the aims of the nation state and to facilitate "the substitution of the religion of the state for the religion of the church." 50 Like Gray, Cavanaugh sees post-Enlightenment secularism as "a chapter in the

\footnotetext{
48 William Cavanaugh, The Myth of Religious Violence (New York: Oxford University Press, 2009), 177.

49 Ibid., 180.

50 Ibid., 177.
} 
history of religion." ${ }^{51}$ However, while Gray would go further to argue that it is a chapter of larger Christian history, and a mutated expression of Christianity, Cavanaugh argues that it is a competing religion in its own right, with its own faith: the sacredness of the nation state. Secular nationalism has replaced so-called "religious" worship. He writes: “...ours is an unliturgical age in most respects, with one enormous exception: the public life of the citizen of the nation-state. Citizenship in secular countries is tied to symbols and rituals that have been invented for the purpose of expressing and reinforcing devotion to the nation-state. ${ }^{352}$ This further supports the idea that all positions are finally faith positions, including all political positions, and that what is at issue in Gray's argument is a conflict of rival faiths.

\section{Gray's Thought as a Christian Chapter IN the History of Religion \\ Gray critiques Enlightenment and utopian thinkers as being shaped by} Christianity, even as they have tried to free themselves from it. He even criticises the New Atheists as being shaped by the very thing they deny. In Straw Dogs he writes:

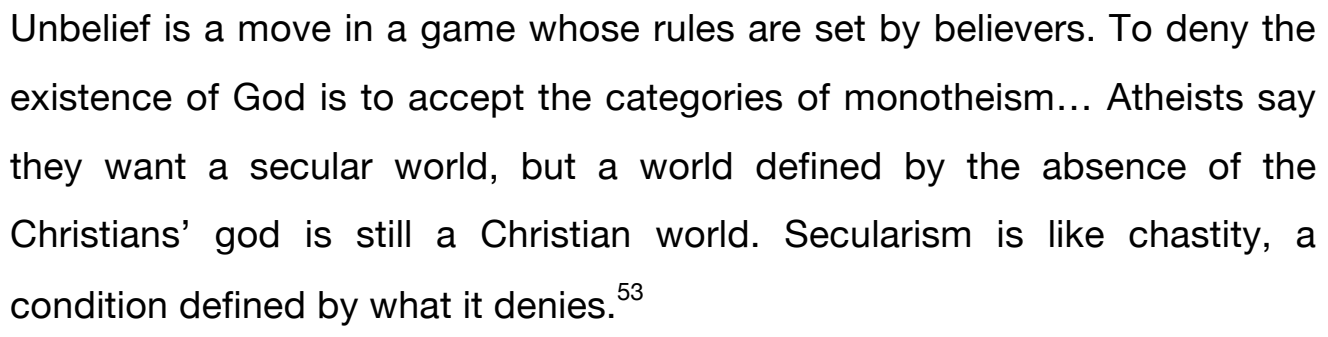

Gray is unaware, however, of the way the horizons of his own thought have been shaped by Christianity, of how his own proposal is in some ways a parody of the

\footnotetext{
51 Gray, Black Mass, 1.

52 Cavanaugh, The Myth of Religious Violence, 178.

53 Gray, Straw Dogs, 126.
} 
Christian gospel. In much the same way that Gray accuses modern, secular politics of being a "Black Mass" - a perversion of Christian eschatological hopes of salvation for humankind - Gray's own proposal is a "Mass" of a similar kind. This is revealed by the horizons of hope that define Gray's proposal and within which his thought resides.

Gray's concern to limit violence in favour of peaceful coexistence is an expression of values that have been shaped by Christianity. In his compelling book Atheist Delusions, David Bentley-Hart demonstrates the way that Christianity irrevocably re-shaped the world:

...how enormous a transformation of thought, sensibility, culture, morality, and spiritual imagination Christianity constituted in the age of pagan Rome; the liberation it offered from fatalism, cosmic despair, and the terror of occult agencies; the immense dignity it conferred upon the human person; its subversion of the cruellest aspects of pagan society....and its elevation of charity above all other virtues. ${ }^{54}$

Bentley-Hart concurs with Gray's assertion that the ultimate dignity and value of the human person is a Christian invention. Gray considers it an illusion, and his proposal of modus vivendi is an attempt to found a politics without recourse to this illusion. Yet his modus vivendi is itself a product of Christianity's anthropological foundations. Implicit in Gray's proposal, and in his wider work, is the assumption that violence is an evil. Gray composes a list of "universal evils" - "to be tortured, or forced to witness the torture of loved ones or compatriots; to be separated from one's friends, family or country; to be subjected to humiliation or persecution, or

\footnotetext{
${ }^{54}$ Bentley-Hart, Atheist Delusions: The Christian Revolution and Its Fashionable Enemies, xi.
} 
threatened with genocide; to be locked in poverty or avoidable ill-health." ${ }^{35}$ These are all "great evils". Gray takes the nature of these evils to be in some way self-evident, arguing that they constrain "the forms of life in which they [human beings] can thrive."56 But in pre-Christian pagan thought these "evils" were believed to be part of the divine order. The "common-sense" realism that advocates the abolition of these evils is, according to Bentley Hart, a child of that "grand reimagining of the possibilities of human existence" ${ }^{57}$ which was the Christian transformation of the world. Gray's self-evident moral insight confirms Bentley-Hart's affirmation that "once the world has been seen in this [Christian] way, it can never again be what it formerly was. ${ }^{158}$ Gray grounds his modus vivendi on the belief that peaceful coexistence is required for human beings to flourish. But the presupposition that human existence can even have such a meaning as "flourishing" - that it could be anything more than a meaningless endurance of the capricious turns of fate - is, Bentley-Hart argues, a Christian one. "For most philosophers and political theorists", Gray observes, "ignorance of religion is a point of professional honour, and they are unaware that many of their views are secular versions of religious beliefs." ${ }^{159}$ It appears Gray unwittingly also falls in this category.

Furthermore, if the existence of a transcendent meaningful teleology is

\footnotetext{
55 Gray, Two Faces of Liberalism, 66.

56 Ibid.

57 Bentley-Hart, Atheist Delusions: The Christian Revolution and Its Fashionable Enemies, 174.

58 Ibid.

59 John Gray, "Reply to Critics," in The Political Theory of John Gray (London: Routledge, 2007), 228.
} 
surrendered, the moral vacuum left will most likely be filled by expressions of the will to power, rather than a modus vivendi. Bentley-Hart explains:

If there really is no transcendent source of the good to which the will is naturally drawn, but only the power of the will to decide what ends it desires - by which to create and determine itself for itself - then no human project can be said to be inherently irrational, or (for that matter) inherently abominable. If freedom of the will is our supreme value, after all, then it is for all intents and purposes our god. ${ }^{60}$

In the wake of the consciousness that Christianity bequeathed the world, human life will "flourish" far less than before. Bentley Hart continues:

This was Nietzsche's greatest fear: the loss of any transcendent aspiration that could coax mighty works of cultural imagination out of a people. When the aspiring ape ceases to think himself a fallen angel, perhaps he will inevitably resign himself to being an ape, and then become contented with his lot, and ultimately even rejoice that the universe demands little more from him than an ape's contentment. ${ }^{61}$

If for "contented ape" we substitute Gray's "straw dogs", we end up at the same place. More likely than a modus vivendi is a war of all against all and, in the absence of a Christianity-inspired humanism of the past, such a project of war and violence cannot "be said to be inherently irrational, or ... inherently abominable."62

Gray's designation of the Christian inheritance of anthropocentrism and teleology as "necessary illusions" is his only solution to the degradation of human existence that the abandonment of this inheritance invites. This begs a final question

\footnotetext{
60 Bentley-Hart, Atheist Delusions: The Christian Revolution and Its Fashionable Enemies, 227.

${ }^{61}$ Ibid., 230.

62 Ibid., 174.
} 
that must be levelled at Gray, which is, why exclude the possibility of genuine faith from the outset? He presupposes that Christian belief is an "illusion". He rejects the Enlightenment thinking and utopianism that Christianity has engendered as inherently violent, while recognising that in its pure form Christian teleological thinking was not violent. He rejects secular humanism on the grounds that it is dishonest in its distancing of itself from its Christian progenitor, yet understands that human existence seems incapable of perpetuating itself in ways that allows it to "flourish" without clinging to the meaning and dignity which Christianity conferred on the human species. He laments the ontological narrowing of human life to one telos, one view of "the good." But, as we will see in the next chapter, Christian theology, far better than Gray's alternative, is able to sustain the unity-in-diversity that appears to be a prerequisite for the flourishing of human existence. Were it not for Gray's unquestioned rejection of Christian faith, he may have discovered theological resources that are able to rescue him from the Scylla and Charybdis of moral hegemony and nihilism, which shipwreck his proposal. It is to these resources - to the Christian vision of human existence - and the ability therein to resolve the tensions within Gray's thought that this discussion turns next.

\section{SUMMARY}

Gray's proposal of a modus vivendi is at odds with his rejection of teleology. Not only does it posit a (sub-) ideal as an implicit telos, it also privileges his own chosen value of peaceful coexistence. Furthermore, his argument rests on the acceptance of values pluralism, which, rather than being a fact about the world, as Gray claims, is in truth a faith position of the very kind of which Gray is critical. The 
only consistent position for Gray would be one of nihilism - a position that proposes nothing. A modus vivendi is also rendered unworkable by the fact that it relies on its adherents renouncing the universality of their values. If that were to occur, a modus vivendi would no longer be necessary.

Gray's account of modern political violence as being the offspring of Christian eschatology ignores the violent tendencies present within secularism and the state-building nationalism that accompanies it. Rather than bearing the seeds of violence, Christianity provides the horizon for Gray's own valuing of peaceful coexistence and human flourishing. 


\title{
CHAPTER 4: HOPE REMAINS
}

\author{
Jürgen MoltmanN's Christian Eschatology
}

\section{INTRODUCTION}

John Gray's philosophy and political proposal highlight the connection between values and a telos - the goal or vision of "the good". Gray's view of the good as "peaceful coexistence" and "human flourishing" privileges the value of tolerance that underpin his modus vivendi. What is less obvious, but has been demonstrated above, is that our presuppositions or assumptions about the way the world is, and in particular, the way humanity is, shape our view of the good (our telos). Because, in Gray's anthropology, human beings are assumed to be irrational individuals with conflicting animal needs, the only "good" that is open to them is one that minimises suffering and conflict - Gray's modus vivendi. Values therefore arise out of the telos of a given tradition or scheme of thought, but the telos is shaped by fundamental assumptions about the world and our place in it. As has been demonstrated, in Gray's thought, these assumptions are a "faith" - an assumption about the world, independent of rational reasons or empirical evidence. It could be argued that all thought rests on these kinds of protological assumptions - that every perspective is ultimately a "faith" perspective, regardless of the rational scheme constructed on top of that foundation.

Christianity, and religion in general, have been characterised as inherently violent in recent times. William Cavanaugh has recently argued that this is a canard; it is a myth deployed in the service of secularisation and the establishment of the 
nation state, as a means to legitimate the "rational" violence employed by the state, in contrast to the "irrational" religious violence from which secularism has "saved us". This chapter will seek to analyse the role and content of Christian eschatology, which Gray has identified as being the source of modern political violence. As the telos of the Christian faith, Christian eschatology also grounds Christian values, one of which (it will be argued) is peace. It also gives expression to fundamental assumptions about the world and about the role of human beings in it. In Christian theological terms, the shape of redemption is already implied in the nature of original creation. Gray's "creation story" is one of original chaos, and even his attempt to provide some form of meaning to human existence cannot avoid the nihil; the nothingness, the void at the core of reality. In order to determine the shape of the Christian telos - eschatology - we must first examine its foundational assumptions about who we are, and what the world is. Gray is correct in saying that for Christians, "human beings have infinite worth because they partake of the divine personality that created them." So it is to the divine person that this discussion will turn first, in order to establish the contours of a Christian ontology, anthropology, teleology and ethics.

Our discussion will focus largely on the theology of Jürgen Moltmann, who in recent times has made significant contributions to the study of Christian eschatology $^{2}$. In particular he has demonstrated how it is ontology (assumptions

\footnotetext{
1 Gray, Enlightenment's Wake, 158.

2 Moltmann's Theology of Hope (1993) has been described as: "One of the most important books to have emerged out of recent Protestant theology. Causing a considerable stir when it was first published in 1965, the book continues to represent one of the most complete and comprehensive
} 
about the way things are) that grounds the telos (the vision of the way that things should be). From this, an ethics can be derived, as the kind of action that best reflects and helps to bring about the telos. In Gray's view, violence is the ethics of utopian politics. In Moltmann's thought, peace and love are the ethics of a Christian "eschatology of hope".

Moltmann addresses the transformation of Christian eschatology into the utopian impulse, and its violent implications. As such, he makes an ideal conversation partner for John Gray. Moltmann's introductory words to The Coming of God, a volume that specifically addresses eschatology, highlight the shared subject matter and perspective between him and Gray. It also provides an excellent introduction to the significance of eschatology for the times in which we live:

The terrors of twentieth-century history irrevocably shattered all nineteenth-century chiliastic and messianic projects, in both their religious and their secular form. What took their place? In many countries and in many sectors of life they were replaced by apocalyptic, whether in its religious or its secular form. Just as millenarianism draws eschatology into history in a positive sense, in order to establish the kingdom of God 'already here on earth' (Heinrich Heine's phrase), modern apocalyptic draws eschatology into history in a negative sense, in order 'already here on earth' to enact the nuclear 'Armageddon' and the ecological 'Chernobyl'.

Consciously or unconsciously, the eschatological thinking of the present day is determined by the messianic visions of the nineteenth century, and by the apocalyptic terrors experienced in the history of the twentieth. What hope can be justified, once we wake up out of the messianic dreams and resist the

statements yet proposed of the importance for theology of eschatology" (From the back cover of the book). There is also an extensive secondary literature engaging with Moltmann's work. A recent study on Moltmann's ethics will be engaged with in this chapter. 
apocalyptic anxieties? What can eschatology mean, if it cannot be drawn into history, either chiliastically or apocalyptically, without destroying the world? As we have seen, the eschatological problem of the present day is not merely theological; it is political too. It is the problem of history itself. ${ }^{3}$

Moltmann's theology describes a Christian eschatology that can underpin a peaceful and hopeful ethical engagement with the social and natural worlds. Moltmann describes a "between space" of ethical engagement, whereby human beings are caught between the present and the perfect future inaugurated through Christ's death and resurrection. This "between space" frees human beings from the hopeless determinacy of the past, without allowing them to indulge in a Promethean utopianism, of the kind that Gray describes as ultimately violent. This has the ability to rescue humankind from the character of modern life as interminable progress - a similarly Promethean punishment of endless repetition of that which has gone before. Both Gray and Moltmann agree that the modern age is condemned to the excesses and impending doom of ecological collapse if a new way of being that surpasses modern consciousness is not embraced. In what follows we will outline Moltmann's account of Christian eschatology, in order to contrast it with its "parodies" and to draw out its significance as a source of political peace and hope, rather than violence

\section{MOLTMANN'S TRINITARIAN ONTOLOGY}

Moltmann begins his contribution to systematic theology with a volume in

\footnotetext{
3 Jürgen Moltmann, The Coming of God: Christian Eschatology, trans. Margaret Kohl (Augsburg Fortress Pub, 2004), 5.
} 
which he develops a "social doctrine of the Trinity." What makes him an excellent conversation partner for Gray's political and ecological concerns, is his proposal that since "God is a community of Father, Son and Spirit, whose unity is constituted by mutual indwelling and reciprocal interpenetration" it follows that "we find the earthly reflection of the divine sociality, not in the autocracy of a single ruler but in the democratic community of free people." ${ }^{n}$ The way that God is conceived, in other words, determines the way that human beings are to be conceived. Theology - and specifically the doctrine of God - has implications for the way that politics is construed.

While it is outside of the scope of this discussion to analyse the (vast) history of Trinitarian theology, it will be helpful to highlight a few significant Trinitarian concepts. First, Jewish monotheism has been the chief determinant for Christian theology; in particular the foundational assertion of the Jewish Shema (a prayer and confession of faith), "Hear, O Israel, the Lord is our God, the Lord is one." However, from early on in its history Christianity asserted the divinity of Jesus Christ, and the distinctive identity of the Holy Spirit. The Trinity is a theological attempt to reconcile the three "persons" of the Christian godhead - Father, Son and Spirit - with the one God of Judaism: one God in three persons. This is the classic formulation of the Trinity, one that involves the philosophical problem of resolving God's oneness with God's three-ness. Moltmann critiques those ways of conceiving the Trinity that

\footnotetext{
4 Jürgen Moltmann, The Trinity and the Kingdom: The Doctrine of God (Fortress Press, 1993), viii.

${ }^{5}$ Ibid.

${ }^{6}$ This is derived from Deuteronomy 6.4.
} 
begin with the oneness of God, arguing that they relapse into simple monotheism, and this has political consequences. If there is one undifferentiated God, then there is also only one will for human beings, and human rule, reflecting the image of God, will be that of "lordship" over others. He writes: "...monotheism was, and is, always a 'political problem' too. Strict monotheism has to be theocratically conceived and implemented, as Islam proves." Monotheism results in political domination rather than freedom. However, it is not on these grounds only that Moltmann rejects the priority of the oneness of God in the formulation of the Trinity.

Moltmann grounds his Trinitarian theology, of God's self-revelation through Jesus Christ, in biblical history. Beginning with the advent of Christ, Moltmann argues that the three persons of the Trinity are primary, which means that the oneness of God becomes the chief problem for Trinitarian theology, rather than how to maintain the integrity of the persons in the face of that oneness. "It seems to make more sense theologically," writes Moltmann, "to start from the biblical history and therefore to make the unity of the three divine persons the problem." ${ }^{8}$ If we begin with Christ as the foundation of God's revelation, then the persons are antecedent to the oneness of God.

The orthodox solution to the "problem" of the unity of the three persons is the concept of perichoresis. While it is a complex doctrine, Alister McGrath explains perichoresis succinctly as follows:

\footnotetext{
${ }^{7}$ Moltmann, The Trinity and the Kingdom, 131.

8 Ibid., 149.
} 
It refers to the manner in which the three persons of the Trinity relate to one another. The concept of perichoresis allows the individuality of the persons to be maintained, while insisting that each person shares in the life of the other two. An image often used to express this idea is that of a "community of being," in which each person, while maintaining its distinctive identity, penetrates the others and is penetrated by them. ${ }^{9}$

This idea establishes the notion of person as inseparable from its relation to other persons. It contradicts the modern notion of the person as a radical individual. McGrath notes that, "This notion has important implications for Christian political thought ... The mutual relationships among three co-equal persons within the Godhead have been argued to provide a model both for human relationships within communities and for Christian political and social theorizing."10 Gray was correct in stating that the concept of the "person" is largely determined by the notion of who God is. However, Gray begins from the concept of the person as individual, a conception that reduces all human relationship to competition and conflict.

\section{TRINITARIAN ANTHROPOLOGY}

Trinitarian theology employs a notion of "personhood" that is in many ways antithetical to modern individuality. Moltmann reflects on the "modern bourgeois world's cultivation of the individual," ${ }^{11}$ noting that its consequence is that:

...every individual must be able to develop himself into a many-sided personality. He only has to observe the equal rights of every other person to

\footnotetext{
${ }^{9}$ Alister E. McGrath, Christian Theology: An Introduction (Blackwell Publishers, 2001), 325.

10 Ibid., 326.

11 Moltmann, The Trinity and the Kingdom, 155.
} 
life, liberty and happiness. The other person is the only thing that limits the development of one's own personality and the realization of one's own self. ${ }^{12}$

Modern individualism, however, stands in contrast to an authentically "trinitarian anthropology", where: "A person is only God's image in fellowship with other people." ${ }^{13}$ In a trinitarian anthropology, the isolated individual is not truly a person.

A trinitarian anthropology overcomes notions of conflict, power and dominance through an ontology of love. Love, understood in this way, consists of finding one's being in relation to another, without losing one's own identity. Once persons are defined through the mutuality of their relationships, human community becomes the ideal - the completion of our individuality, rather than the limitation of it. Moltmann writes that: "the Trinity corresponds to a community in which people are defined through their relations with one another and in their significance for one another, not in opposition to one another, in terms of power and possession." ${ }^{\text {"14 }}$ Elsewhere, Moltmann explains: “...people are made in the image of God. But the divine image is not the individual; it is person with person." More than that, it is finding oneself in the other. ${ }^{15}$ A person is a relation, in a Trinitarian ontology, rather than an independent individual. The ideal relation is that of love - each finding their being in the other.

\footnotetext{
12 Ibid.

13 Ibid.

14 Ibid., 198.

15 An example of how human nature demonstrates this trinitarian personhood is the way that self-identity is developed in an individual through the interactions of others and the way others "intend" that person. See Alastair McFadyen, The Call to Personhood: A Christian Theory of the Individual in Social Relationships (Cambridge: Cambridge University Press, 1990).
} 
A trinitarian anthropology requires a redefinition of freedom - the highest value of liberal politics - and provides a synthesis between the antithetical (and as Gray would say, incommensurable) demands of a notion of freedom founded on the understanding of persons as individuals. In the modern, individualistic conception of freedom, Moltmann notes that: "Everyone finds in the other person a competitor in the struggle for power and possession. Everyone is for everyone else merely the limitation of his own freedom."16 However, if a person is not an individual but, on the contrary, is defined by their relation to others, then freedom assumes a social dimension. This radically transforms the concept of freedom and overcomes the incommensurability of rival freedoms. Moltmann explains:

It is only in love that human freedom arrives at its truth. I am free and feel myself to be truly free when I am respected and recognized by others and when I for my part respect and recognize them. I become truly free when I open my life for other people and share with them, and when other people open their lives for me and share them with me. Then the other person is no longer the limitation of my freedom; he is an expansion of it. ${ }^{17}$

When conceived in a trinitarian manner, freedom is not limited by sociality; it is enhanced and expanded by it. The being of one finds its completion and confirmation in the being of the other(s). The fundamental conflict at the foundation of human political life is transformed into a fundamental harmony.

A trinitarian understanding of personhood points to a telos of harmony for political life. If human being, being ontologically constituted by the trinitarian God, is

\footnotetext{
16 Moltmann, The Trinity and the Kingdom, 215.

17 Ibid., 216.
} 
understood to be that of mutual relation, then this is definitive of the ideal political forms for human society. Moltmann scholar Timothy Harvie, in his volume Jürgen Moltmann's Ethics of Hope, contrasts the consequences of a trinitarian theology with that of a "Monistic" theology:

Moltmann opposes his understanding of perichoresis to monistic, or what he calls monotheistic, notions of God. Moltmann then applies this theological discussion to politico-ethical praxis by arguing that one's conception of the divine automatically results in particular human analogues which seek to mirror the divine reality through a political mimesis of God's inner life. Depending on the prior construal of God as either monotheistic or as Trinity, Moltmann argues that the resultant mimetic activity in the political realm is either totalitarian and oppressive in the case of the former, or communal and liberating in the case of the latter. ${ }^{18}$

A trinitarian ontology suggests not only an ontology of love, but also an anthropology

- and hence a politics - of peaceful human co-existence. However, the relationship between Christian theology and politics, in Moltmann's thought, is a complex one which can only be understood in the context of eschatology.

\section{Moltmann's Eschatology: God Will Be All in All}

For Moltmann, eschatology is definitive of the way that human beings should understand their engagement in the present. The eschatological future that Moltmann describes, however, is not the disembodied after-life of so much Christian

18 Timothy Harvie, Jurgen Moltmann's Ethics of Hope (Surrey: Ashgate, 2009), 7. 
folk-theology. ${ }^{19}$ Rather, he describes the future of creation as New Creation. In order to understand the future of the present creation, however, we must first understand its beginning. Moltmann's theology of creation also springs from his Trinitarian theology.

\section{Moltmann's Theology of CREATion ${ }^{20}$}

Moltmann's trinitarian theology challenges modern analytic thinking and requires an "ecological" approach to theology. Modern scientific thought is essentially a rationalist mode of thinking that seeks to know in order to control and use. It views all objects as "equipment" or as objects intended for human use and consumption. This kind of thinking reduces the world to a human resource - the very anthropocentric error that, Gray claims, "encourages us to believe that, unlike any other animal, we can understand the natural world, and thereby bend it to our will."21 A consistently trinitarian approach to theology, and in particular to the doctrine of creation, cannot be defined by such a "monistic" approach. Moltmann explains:

If a doctrine of creation is to be ecological, it must try to get away from analytical thinking, with its distinctions between subject and object, and must strive to learn a new, communicative and integrating way of thought. This means that it will have to revert to the pre-modern concept of reason as the organ of perception and participation.

\footnotetext{
19 This is my own term, indicating the status of much of the "grass roots" theology of the (in particular evangelical) church to be a form of folklore, passed on from person to person, but without a sufficient grounding in scripture, tradition or academic theology.

20 The term "creation" is used here, not with respect to the context of "creation and evolution" but to refer to "nature as gift" and the implications that proceed from that, in contrast to a purely materialist view of nature as resource.

${ }^{21}$ Gray, Straw Dogs, 23.
} 
[T]he concern that motivates cognition changes. We no longer desire to know in order to dominate, or analyse and reduce in order to reconstruct. Our purpose is now to perceive in order to participate, and to enter into the mutual relationships of the living thing.

[A] theological doctrine of creation in our own time is also guided by the will to find a way into the community of creation, to reawaken the awareness of that community and to restore it. ${ }^{22}$

An "ecological" approach to a doctrine of creation overcomes Gray's accusation of "anthropomorphism" against Christian theology, and demonstrates how Christian anthropology, far from causing the objectification and destruction of the world, can underwrite the "green" approach that Gray advocates.

Like Gray, Moltmann is critical of modern conceptions of "nature", and the Enlightenment faith in progress that is concomitant with such conceptions. The difference between modern and pre-modern conceptions is, in Moltmann's view, the pursuit of power: "The acquisition of power, the increase of power, and the securing of power: these, together with 'the pursuit of happiness,' may be termed the values that actually prevail in modern civilizations." ${ }^{23}$ Consequently, when nature is objectified, human beings reduce themselves.

[T]hrough this method the human being confronts nature from the outset and in principle as its ruler. $\mathrm{He}$ is no longer one member of the community of creation; he confronts creation as its lord and owner. Consequently he can no longer identify himself in terms of body and nature. He becomes merely the subject of cognition and will. The reduction of the natural environment to

\footnotetext{
22 Jürgen Moltmann, God in Creation: A New Theology of Creation and the Spirit of God (Fortress Press, 1993), 2-4, passim.

23 Ibid., 26.
} 
the status of mere objects corresponds to this subjectification of the human being. ${ }^{24}$

A human being is understood only as a consumer and nature only as a resource for consumption. We are excluded from the "equilibrium" which pre-modern societies enjoyed and valued in their relationship to the natural world, the state of equilibrium that Gray praises as the exemplary virtue of the "Gaia hypothesis", to which he subscribes. ${ }^{25}$ Moltmann's criticism of "progress" is as stringent as Gray's and runs along similar lines:

Everywhere uncontrollable processes of growth have sprung up: growing populations, industrial growth, growing pollution, a growing use of energy, a growing exposure to stimuli, and growing mental and spiritual instability among men and women. These processes are interdependent and mutually accelerating. 'Progress' is no longer an expression of hope, as it was in the nineteenth century; it is a fate to which people in the industrial countries feel themselves condemned. When ancient civilized nations are assessed as 'under-developed' or 'developing', this merely shows the mindless imperialism of this ideology of progress, which judges everything on the basis of its own condition, and which aims merely at its own hegemony. ${ }^{26}$

Moltmann and Gray agree that progress is a destructive force, founded on an

\footnotetext{
24 Ibid., 27. Significantly, this is an insight that Moltmann attributes to Heidegger.

25 Gray, Straw Dogs, 33. Gray writes: "Gaia theory re-establishes the link between humans and the rest of nature which was affirmed in mankind's primordial religion, animism. In monotheistic faiths God is the final guarantee of meaning in human life. For Gaia, human life has no more meaning than the life of slime mould." Interestingly, Moltmann's point is that it is precisely monotheism, in contrast to Trinitarianism, that results in human exploitation of nature. However, the Gaia Hypothesis simply reverses the power struggle, claiming superiority and dominance for the earth over human beings, who are of little worth (as evidenced by their "slime mould" status in Gray's quote).

${ }^{26}$ Moltmann, God in creation, 28.
} 
anthropocentric error that values all things only in terms of an individualistic personhood.

Not only has the analytic approach to the world resulted in the "ideology of progress"; it is also concomitant with violence. When entities, whether human or non-human, are understood as monads, and not through a Trinitarian ontology such as outlined above, then violence is an inevitable outcome. Moltmann makes this observation:

[W]e should not ... try to grasp the internal relationships of human society and the inner differences of individuals purely analytically, by way of more and more demarcations and exclusions ... In definitions which are arrived at by way of exclusions and divisions, violence is made the principle. ${ }^{27}$

The way that reality is conceived and related to determines its future. If irresolvable conflict is posited at the heart of human society, through an analytic hermeneutic, then violence is the outcome. Gray's thought is consistent with this; in his values pluralism he posits an irresolvable conflict at the heart of social relations. Consequently, he views violence as inherent. But when individuals and society are viewed as parts of a larger, integrated Gestalt, the future of society can be construed in hope.

Moltmann's doctrine of creation begins with the assertion that it belongs primarily to God. While Gray criticises Christianity for inaugurating an anthropocentric view of nature, Moltmann describes a Christian view of nature in the following terms: "If the world is God's creation, then it remains his property and

\footnotetext{
27 Ibid., 246.
} 
cannot be claimed by men and women. It can only be accepted as loan and administered as a trust." ${ }^{28}$ Creation is a gift - but a gift on loan, not one which human beings can do with as they please.

The consequence of viewing creation as gift affects the approach one must take to it. If it is God's gift, and not merely a resource appropriated to anthropocentric goals, then scientific "knowledge" is not an appropriate method for truly understanding the world. From the "faith" that the world is a gift from God, certain kinds of "knowledge" proceed. Moltmann writes:

Through scientific terms we define, and through definitions we pin things down and make objects identifiable. But belief in creation only arrives at the understanding of creation when it recollects the alternative forms of meditative knowledge. 'We know to the extent to which we love,' said Augustine. Through this form of astonished, wondering and loving knowledge, we do not appropriate things. We recognise their independence and participate in their life. We do not wish to know so that we can dominate. We desire to know in order to participate. This kind of knowledge confers community. ${ }^{29}$

The understanding of this world as creation, and in a trinitarian framework, invites a new perception that transcends anthropocentrism and unites human being and non-human being in community. It is obvious how necessary this kind of knowing is in a world now on the brink of ecological collapse because of humanity's history of domination of nature. Gray is clear that it is this "anthropocentric error" which has caused the current ecological crisis. Gray subscribes to "Gaia theory," which, he

\footnotetext{
28 Ibid., 30.

29 Ibid., 32.
} 
argues, "re-establishes the link between humans and the rest of nature." 30 In fact, Gaia theory privileges nature over human being, and offers no hope for human society, only warnings. Moltmann, however, argues that:

[l]f this anthropocentrism is replaced by a new cosmological theocentrism [then t]he creatures of the natural world are not there for the sake of human beings. Human beings are there for the sake of the glory of God, which the whole community of creation extols. The more human beings discover the meaning of their lives in joy in existence, instead of in doing and achieving, the better they will be able to keep their economic, social and political history within bounds. ${ }^{31}$

Rather than privileging one or the other, as a monadic ontology is wont to do, a trinitarian ontology offers hope in the promise of harmony and communion between human beings and the earth in which human beings view themselves and the world theocentrically. This theology offers a genuine hope for humanity's harmony with nature, as opposed to Gray's apocalyptic predictions of human extinction and catastrophic conflicts engendered by resource scarcity.

\section{NeW CREATion}

Moltmann's eschatology has significant implications for the way creation is viewed and for the kind of politics that it suggests. The end or telos of this creation is a new creation. Creation is not given as a static, once-and-for-all world. Rather, the Christian view of the world is teleological. This telos, as Gray points out in Black Mass, is the renewal of the heavens and the earth: "Jesus and his first disciples believed that the world was destined for imminent destruction so that a new and

\footnotetext{
30 Gray, Straw Dogs, 33.

31 Moltmann, God in creation, 139.
} 
perfect one could come into being." ${ }^{32}$ However the transition occurs, whether through some kind of destruction or some more subtle transfiguration, Moltmann maintains that the future of creation cannot be annihilation:

The expectation of 'the end of the world' is a vulgar error... it is gnostic in origin, not biblical... Anyone who believes in the God who created being out of nothing also believes in the God who gives life to the dead. This means that he hopes for the new creation of heaven and earth. ${ }^{33}$

The future of present creation is as a renewed, material creation. New creation differs from the current creation in that God will make himself fully present to the new creation - he will indwell it, making it his "home". "In the gift and through the powers of the Holy Spirit," writes Moltmann, "a new divine presence is experienced in creation. God the creator takes up his dwelling in creation and makes it his home... The presence and efficacy of the Spirit is the eschatological goal of creation and reconciliation. All the works of God end in the presence of the Spirit." ${ }^{34}$ When God is fully present in his creation, it becomes "glorified" and achieves the telos for which it was created. God becomes one with his creation, in much the same way that the members of the trinity are one - in a perichoresis - God indwells his creation and his creation is also "in him". This is a vision of ultimate peace, where the whole cosmos is united and in harmony - harmony in human society and in human relations with creation - without being dissolved into sameness. Through the trinitarian ontology of oneness in diversity, the cosmos, as new creation, is able to attain to oneness while

\footnotetext{
32 Gray, Black Mass, 5.

33 Moltmann, God in creation, 93.

34 Ibid., 96.
} 
maintaining its character as a plural, material creation.

Understanding the relationship between "the heavens and the earth" is important for understanding Moltmann's biblical eschatology and the utopian impulse that, as Gray has argued, emerges from a secularised version of the Christian hope. First, the dual nature of creation as heavens and earth is significant. Moltmann expresses cogently the significance of these two spheres of creation as follows:

\begin{abstract}
We call the side of creation which is open to God 'heaven'. From heaven and through heaven God acts on earth. Heaven represents the relative 'beyond' of the world, and the earth is the relative 'this-worldliness' of heaven. In heaven creation has its relative transcendence. In the earth creation finds its relative immanence. The ec-centric world open to God possesses in itself the dialectical structure of transcendence and immanence. ${ }^{35}$
\end{abstract}

As a creation possessing the qualities of immanence and transcendence, the dualities and dichotomies of actual/ideal and one/many are synthesised. The conflict between the universalism of the "one" and the limitations and variety of "the many" are resolved in this dialectic. Creation is always open to and informed by the universals, the ideal: "the heavens", and the ideal, the good, is always being incarnated, achieving immanence in "the earth". As was demonstrated in the previous chapter, Gray's rejection of the notion of perfection due to the limits of rationality, ${ }^{36}$ and his concomitant rejection of teleology - of even the possibility of progress toward an ideal - stood in discordant antithesis to the implicit teleology of

\footnotetext{
35 Ibid., 182.

${ }^{36}$ Gray, Two Faces of Liberalism, 39.
} 
his modus vivendi. Despite Gray's claim that the plurality of values precludes the possibility of universal values, his own proposal aimed to bring unity to diverse ways of life under the value of peaceful coexistence, in order to achieve the good or telos of human flourishing. The dialectical notion of creation as "heavens and earth" reconciles the tension between "the one and the many", the ideal and the actual, which is a problem not only for Gray's philosophy, but also perennially for philosophy in general. ${ }^{37}$

Moltmann identifies the utopian error that transforms Christian eschatology from God's providential plan into a (potentially - and often actually - violent) human project. He describes it as the collapsing of the heavens-earth dialectic, thus denying the earth the possibility of transcendence. In Christian eschatology, the heavens and the earth will become one; the sphere of the actual will become also the sphere of the ideal, and vice versa, when Christ returns. ${ }^{38}$ However, when the heaven of the world to come (the new heaven and earth) is reduced to the heaven of the historical future of this creation, then the utopian impulse is born. Moltmann notes of Marx that he:

...replaces the indissoluble duality of heaven and earth by the dissoluble difference between humanity's present condition and its historical future. But this historical future can only be realized in the revolutionary imperative ... At the same time, the all-human society must be nothing less than "heaven on

\footnotetext{
37 Copleston, A History of Philosophy, 1:23.

38 In fact, this future has already been anticipated in the resurrection of Christ, and through the indwelling of God's Spirit in creation; in particular, in his indwelling in men and women.
} 
earth' ... But this means that this perfect, all-human - which is to say Communist - society must be a society without heaven. ${ }^{39}$

Moltmann notes that the removal of the transcendence of the heavens from "above" to "before" us removes the prospect of hope for change and for a genuinely new future. The future will only be the pre-determined repetition of the past (as Gray assumes in his assertion of the cyclical nature of history). ${ }^{40}$ Moltmann insists that:

[A] historical future without heaven cannot be the forecourt of hope and the motivation for any historical movement. A 'transcending without transcendence' ... turns infinity into indefinite endlessness, and makes of the striving for fulfillment merely an 'on and on'. ...[H]eaven without God is incapable of making accessible to the earth a future in which men and women might seek for happiness, salvation, the disclosure of what is hidden, identity and essential being. Without God's creative potentialities for the world, worldly potentialities remain determined by presently existing reality and are totally congruent with that. ${ }^{41}$

Using the language of Millenarianism, it can be said that utopian thought reduces the millennium to a historical time, rather than seeing in it the transformation of time. Gray begins his account of Christian Millenarianism with Schweitzer's account of Jesus' ministry as characterised by disappointment that "the new kingdom did not arrive." 42 However, Moltmann makes clear that Schweitzer's

\footnotetext{
39 Moltmann, God in Creation, 178.

40 Gray, Straw Dogs, 23.

41 Moltmann, God in Creation, 180-1.

42 Gray, Black Mass, 9.
} 
anticipation of the millennium ${ }^{43}$ as an historical event within history is mistaken:

Schweitzer ... consistently abolished eschatology altogether. [His] error was to transpose eschatology into time, instead of seeing in eschatology a transformation of time itself. But true eschatology is not about future history; it is about the future of history. Anyone who, like Schweitzer, 'imperiously forces' eschatology into history has already abandoned it.

The interpretation of the millennium as a future in time was congruent with the utopian thought of Schweitzer's day. However, both Christian Millenarianism and utopianism (which is secular Millenarianism) are, for Moltmann, actually the abandonment of a true eschatology.

Moltmann contrasts utopian thinking and historical Millenarianism with what he calls the "messianic" interpretation of eschatology. The ideal future is not to be historically located at "the end of history" as its consummation and as arising out of its past; it is not the logical conclusion of this world. However, it is still analogous to this world, and is the transformation of this world. The symbol of this hoped-for transformation, for the Christian, is the resurrection of Christ. Moltmann explains:

Just as the raised Christ does not develop out of the crucified and dead Christ, the novum ultimum - the ultimate new thing - does not issue from the history of the old. Between the old and the new, the New Testament sets the death of Christ, and the dying-with-Christ-to-this-world symbolized by Christian baptism. The new thing is the surprising thing, the thing that could never have been expected. ${ }^{44}$

\footnotetext{
43 "Kingdom" and "millennium" are used interchangeably here for the rule of God, which is the idea that both words express. The millennium is the time of Christ's rule on the earth and is derived from Revelation 20.

44 Moltmann, Coming of God, 28.
} 
The future is not determined by the past, but neither is it discontinuous with it, in a way that would make the present irrelevant. The messianic future of the world is a transformation of the world; hence it is a hopeful future, and one that bears upon the present.

Christian eschatology is a doctrine of hope that seeks to free history from necessity and the determination of its past, in order to open the possibility of a new future. For Moltmann, the past is dominated by the paradigm of modernity and the apocalyptic future that (Gray agrees) it seems condemned to. With eschatology, however, a radically different future is made possible. Moltmann explains the determinacy of the past and the hope of the future as follows:

The messianic interpretation of the experience of the moment that ends and gathers up time is the redemption of the future from the power of history. The power of history is exercised by the mighty. They have to extend their victorious present into the future in order to augment and consolidate their power. Their future is without an alternative, and devoid of surprises. It is no more than the prolongation of the present state of possession, and its expansion. Their future is therefore extrapolated from the tendencies and trends of their past and present. Their future is planned and projected future, for only the person who has the power to implement and enact can plan and project. If the modern world itself is 'the modernity project' undertaken by the powerful people in Western society, then the future of this project will be perceived in two ways by those caught up in it: as a chance for permanent modernization, and as the compulsion to progress. 'The person who rides on a tiger can never get off again', says the Chinese proverb. It is true that today there is very little optimism about the future in the modernity project, but in science and technology the pressure for progress is still unchanged, under 'the compulsion' of competition. 
The messianic interpretation sees 'the moment' that interrupts time, and lets us pause in the midst of progress, as the power for conversion. At that moment another future becomes perceptible. The laws and forces of the past are no longer 'compulsive'. God's messianic future wins power over the present. New perspectives open up. The deadliness of progress towards the economic, ecological, nuclear and genetic catastrophes is recognized; and the modern world's lack of future is perceived. The way becomes free for alternative developments. I should like to call this the redemption of the future from the power of history in the kairos of conversion. Only that will again make theological eschatology possible, for through that, hope as a theological category will be redeemed from the ruins of historical reason. ${ }^{45}$

Like Gray, Moltmann finds no hope in the modern myth of progress; rather he makes similar predictions of disaster and extinction. However, Moltmann sees in Christian eschatology freedom from the necessity of this future - a future that, Gray thinks, may well be unavoidable.

\section{The Politics of Eschatology}

Ethics are the product of a telos, a goal or a view of the good toward which human beings strive. The Christian telos, as interpreted by Jürgen Moltmann, is a transformed cosmos, where God is the "all in all"46 - a cosmos that is united with itself and with God in ultimate peace and harmony, without being dissolved into sameness. This will result in harmony between human beings and between humanity and nature. This vision of the end informs Christian ethics, but in complex ways. In

\footnotetext{
45 Ibid., 45-6.

461 Corinthians 15.28 .
} 
his Jürgen Moltmann's Ethics of Hope ${ }^{47}$ Timothy Harvie explains how in Moltmann's theology, a Christian eschatology informs a non-utopian ethics:

It is noteworthy that redeemed humanity may not attempt to bring about God's promised future. It is fundamental to Moltmann's conception of hope that it is God in Christ alone who is able to create an eschatological future. However, a community defined by its hope for the eschatological future does act in ways commensurate with this future." ${ }^{48}$

Human beings cannot bring about God's future for the world - that is not the motivation for a Christian ethics. Rather, Christian ethics is shaped by the future that is promised by God. Even the ability to live in ways commensurate with that future is a gift of God through the Spirit. As Harvie explains:

Thus, there is both an open and a closed aspect to the possibility of human participation in the Kingdom of God. It is open ethically to human involvement as life empowered by the Spirit to live commensurately with the eschatological Kingdom of God through liberating praxis and restoration of the earth. It is closed to human involvement in the sense that consummation of the Kingdom can only come about through the eschatological working of God - that is, the resurrection of the dead and the redemption of the cosmos. $^{49}$

Humanity may live in ways commensurate with the "Kingdom" but humans do not bring it into being. Rather, their lives are determined by that future more than by the past.

The new future opened up by the promise of God in Christ's resurrection - the

\footnotetext{
47 Harvie, Jurgen Moltmann's Ethics of Hope.

48 Ibid., 23.

49 Ibid., 45.
} 
promise of a transformed cosmos - provides a new "ethical space" for human beings. This space is a "between-space" or "interval"50 between the promise of the future that God will bring about, and the consummation of that promise. It opens history to a new future, and enables human beings to participate in that future through the power of the Spirit. Harvie explains it as follows:

This between-space is in essence the content and form of the promised future ... but enacted through the creative work of God in such a way that in Christ humans may now participate in this space. The space is in contradistinction to the world as it preceded the creative work in the promise while at the same time re-creating that world through a setting-in-force bringing history to consummation. In this sense, Christian hope and the fulfillment of the promise remain entirely the work of God and yet simultaneously remain a sphere for human participation. ${ }^{51}$

The between-space stands "in contradistinction to the world" in that it exists in ways commensurate with the new future of peace and harmony, rather than the imperfect past.

The between-space created by God's promise in Christ is a space of political liberation, for the Christian. Moltmann notes that the character of Christian moral praxis is informed by both the perichoretic nature of the Trinity, which finds its life in the other, and in the expression of this essential nature in Christ's identification with the weak, poor and sinful. ${ }^{52}$ The consequent political praxis, then, is one of solidarity

\footnotetext{
50 Jürgen Moltmann, Theology of Hope: On the Ground and the Implications of a Christian Eschatology (Fortress Press, 1993), 103.

51 Harvie, Jurgen Moltmann's Ethics of Hope, 28.

52 Jürgen Moltmann, The Crucified God: The Cross of Christ as the Foundation and Criticism of Christian Theology, trans. R. A. Wilson (Fortress Press, 1993), 154.
} 
and political liberation. In this way, as Harvie explains, Moltmann's conception of Christian political praxis avoids being utopian:

[T]he themes arising from the love witnessed in the Trinitarian history of the Son is a life-giving openness for the other. However, because these hopes are rooted in the cross and its inseparability from the resurrection, it is not a utopian hope. Instead, it is a hope which enters the eschatologically unfulfilled situations of the present in open, loving solidarity with those who suffer. Thus, as instruments of God empowered by the Spirit for the Kingdom, Christian moral action becomes not just a ‘walking with' suffering, but a journey towards eschatological healing and redemption...This eschatological understanding of Christian moral living, when seen in Trinitarian perspective, necessarily leads from psychological liberation to political liberation. ${ }^{53}$

An ethics informed by the future, but rooted not in human agency but in God's power to resurrect that future from a "dead" past, enables human beings to engage in hopeful political action toward liberation for all who suffer. While freed from the responsibility to make that future happen, they are empowered by the presence of that future through God's empowering presence in the Spirit. ${ }^{54}$

The character of Christian praxis, as determined by its eschatology, must be anti-violent and inherently peaceful. A telos of ultimate peace does not by itself automatically guarantee a peaceful ethic. As Gray shows ${ }^{55}$, peaceful ends have been

\footnotetext{
53 Harvie, Jurgen Moltmann's Ethics of Hope, 135-6.

54 Due to limitations of space, it will have to suffice, by way of explanation, for it to be noted here that the Spirit is referred to as the "downpayment" or "pledge" (Gk. arrabon) in the New Testament - he is the partial presence and guarantee of the future, as well as the power that enables that future to be realized.

55 Gray, Black Mass.
} 
frequently used to justify violent means. However, the character of the Christian telos is unique in that, as divine promise, it is guaranteed as a gift, so that ethical causality is reversed. Rather than acting in a particular way to bring about a particular outcome, in Christian eschatology, the promised outcome informs a particular way of acting. The future works towards the present, transforming it. When combined with a trinitarian anthropology of persons as relations, the praxis of the present is construed as determinedly peaceful, loving and liberating. The character of Christian ethics as empowered by the future means that the poverty and violence of the present are actively resisted and transformed. Moltmann writes that: "anyone who really says 'yes' to life says 'no' to war. Anyone who really loves life says 'no' to poverty. So the people who truly affirm and love life take up the struggle against violence and injustice. They refuse to get used to it. They do not conform. They resist." ${ }^{\text {"6 }}$ Or from another perspective; if, as trinitarian anthropology insists: "the other person is no longer the limitation of my freedom; he is an expansion of it,"57 then violence toward the other is unthinkable - it is violence toward oneself. In this ontology, oneness, wholeness, peace and prosperity can only happen together. Only as a united whole can human beings find fulfillment and completion in their identity as persons.

\section{SUMMARY}

Jürgen Moltmann's theology demonstrates how a Christian eschatology,

\footnotetext{
56 Jürgen Moltmann, The Spirit of Life: A Universal Affirmation (Fortress Press, 2001), xii.

57 Moltmann, The Trinity and the kingdom, 216.
} 
combined with a trinitarian ontology, provides the intellectual resources for engaging in a hopeful and peaceful ethics that works toward universal solidarity and liberation. While such a lofty telos seems unattainable for human beings, Moltmann demonstrates that it is its very nature as "promise" that relieves human beings of responsibility to create this future. It is God's future, promised in the death and resurrection of Christ, and guaranteed in the gift of the Spirit, who is the presence of, and the empowerment to live in ways commensurate with, this future. Human beings who engage in the pursuit of this future can thereby work in hope to transform the present, without the need to sacrifice it to the future. Rather, the past has been taken up and sacrificed already in Christ, and through resurrection has been transformed into the redeemed future. 


\section{CHAPTER 5: CONCLUSIONS}

John Gray's central assertion in Black Mass is that "Modern politics is a chapter in the history of religion." ${ }^{1}$ He claims that modern politics has adopted the Christian idea of salvation, albeit in secularised form, and that this has made modern politics both teleological and utopian. The consequence of this has been that modern politics is inevitably violent, as the present peace is sacrificed in order to bring about the ideal future. In Gray's thought, values pluralism destroys all such notions of "the ideal". Values pluralism is the idea that human values are irreducibly plural. Therefore there can be no ideal system to which politics may aspire, since the incommensurability of values, and their inability to be combined without loss negates the idea of the perfect. Gray proposes that a modus vivendi - a system that enables a plurality of value-laden cultures to coexist peacefully, through political negotiations - is the best system for a values pluralist.

Gray also claims that values pluralism negates the notion of teleology and consequently negates the notion of human meaning. If there is no ideal (as Gray claims there isn't) to which human beings may strive, then the idea of human meaning - including the Enlightenment ideal of progress - is meaningless. Gray is pessimistic about human life and its future. He subscribes to Gaia theory, which understands the Earth as an organism that, like all organisms, always finds equilibrium. Gray predicts that human beings will either destroy themselves through ecological disaster, political conflict

\footnotetext{
${ }^{1}$ Gray, Black Mass, 1.
} 
that is motivated by the scarcity of resources, or at least have the human population significantly reduced as a consequence of our ecological disaster.

In my critique of Gray I have highlighted the inherent teleology and privileging of values in his modus vivendi. By virtue of being a vision of "the Good," Gray's modus vivendi is as much a telos - albeit a sub-ideal or contingent telos ${ }^{2}$ - as the political systems that he critiques. Furthermore, it privileges a form of relativism over those who hold to universal notions of truth. In fact, the plurality of cultures that Gray wishes to bring together in a modus vivendi are, many of them, dependent on a belief in the universality of their values for their existence. Consequently, Gray's modus vivendi is a privileging of the value of peaceful coexistence in a universalising way at the expense of other universal values.

Gray's values pluralism is an assumption about the world, and performs the same role in his thought that ideas such as progress and meaning do in the Enlightenment thinking of which he is so critical. Gray labels these assumptions "faiths" or "myths"; he writes of "Enlightenment faith" ${ }^{3}$ and "the myth of progress," ${ }^{4}$ arguing that these beliefs about the world are articles of faith, rather than truths about the world. Gray's own values pluralism, however, is no less a faith. It is an assumption about the irreducible plurality of human life that is insufficiently justified by Gray. Critics

\footnotetext{
2 I define this term in my critique of Gray as: a telos that is contingent on the imperfectability of human existence, rather than one that is founded on the idea of human perfection.

3 Gray, Black Mass, 104.

4 Gray, Al Qaeda and What It Means to Be Modern, 118.
} 
of Gray have noted that he rejects the myth of progress in favour of his own "myth of diversity." 5

Gray's own argument, it appears, is also a history in the chapter of religion. He rejects notions of ultimate unity in favour of an ultimate plurality, and this is an article of faith for him. Consequently his vision of the good is as prone to violence as those who destroy plurality in the pursuit of oneness. A modus vivendi destroys the possibility of a universal pursuit of truth and meaning. Further, Gray's ontology (or rejection of any ontology) brings human life to the brink of the nihil, where actually not even a modus vivendi is possible. Gray's anthropology reduces human life to a meaningless, material existence that can offer no reason for choosing peace over conflict or tyranny over democracy. In Gray's view, this is the plain truth about human existence, and one that human beings avoid through their faith in the "illusion" of human meaning. This illusion is one that Gray believes is necessary, which reveals a conflict in his thought - he believes meaning to be an illusion, but he doubts that human beings can live without this illusion. This reduces his view of human life almost to absurdity. In my critique of Gray, I have noted that the fact that human beings assume a meaning for their lives perhaps indicates that Gray's faith (given that his assertion of human meaninglessness rests on his faith in values pluralism) may be misplaced.

In my final chapter I have outlined the broad strokes of a Christian theology, as presented in the thought of Jürgen Moltmann, that addresses

\footnotetext{
5 Morgan, “Gray's Elegy for Progress," 125.
} 
Gray's main concerns. Beginning from the prototypical trinitarianism of the Christian faith, Moltmann describes the consequent Christian ontology and anthropology in terms that demonstrate the inherent peacefulness of Christian theology. Furthermore, the Trinity is a complex idea that provides for the resolution of the primordial conflict between "the one and the many." Trinitarian thinking also redefines human being as "persons in relation"; an idea that posits a potential harmony as fundamental to all human being; one that offers the promise of genuine human unity without the threat of dissolving human individuality. In fact, sociality and individuality are mutually reinforcing, in a trinitarian anthropology. Not only does this resolve tensions within human sociality; it also provides hope for the planet in providing the intellectual resources for an ecological understanding of nature as "creation" - as a gift that human beings cannot merely objectify as pure resource, but which they must stand in relation to as fellow creatures.

Moltmann's theology also describes a Christian eschatology that can underpin a peaceful and hopeful ethical engagement with the social and natural worlds. Moltmann describes a "between space" of ethical engagement, whereby human beings are caught between the present and the perfect future inaugurated through Christ's death and resurrection. This "between space" frees human beings from the hopeless determinacy of the past, without allowing them to indulge in a Promethean utopianism, of the kind that Gray describes as ultimately violent. This has the ability to rescue human kind from the character of modern life as interminable progress - a similarly Promethean punishment of endless repetition of that which has gone 
before. Both Gray and Moltmann agree that the modern age is condemned to the excesses and impending doom of ecological collapse if a new way of being that surpasses modern consciousness is not embraced.

\section{TOWARD A NEW CONSCIOUSNESS}

It is to the shape and direction of this future consciousness that this discussion now inevitably points. While the limits of space will allow only a cursory glance in this direction, this conclusion will highlight where fruitful research into this field may begin.

In his rejection of human meaning, Gray turns to Martin Heidegger's idea of Gelassenheit, or "releasement" as he translates it. Gray describes Gelassenheit as "the mode of 'releasement' in which we let things be rather than aiming wilfully to transform them or subject them to our purposes." Gray sees this mode of being as the answer to the problems of anthropocentrism. In establishing a new relationship with the earth that is not solely based on human subjectivity, Gray believes "that a turn in our inherited traditions of thought is accomplished, which opens up the possibility of profoundly different forms of human community dwelling together on the earth in peace."7 Gray also sees in Heidegger's Gelassenheit, a turn toward Schopenhauer and his rejection of willing, writing that in his turn toward Gelasseneit, Heidegger "did little more than return to Schopenhauer by a

\footnotetext{
${ }^{6}$ Gray, Enlightenment's Wake, 229.

7 Ibid.
} 
roundabout route." ${ }^{8}$ Gray writes that the essence of Schopenhauer's thought on the rejection of willing is the idea "that we achieve compassion for other living things by 'turning away from the Will' - by ceasing to care about our own well-being and survival." "In this way, Gray sees humanism as finally surpassed, and the error of anthropocentrism, with its inherent teleology and concomitant "meaning" for human life, is undone.

Putting aside for now the vision of "profoundly different forms of human community dwelling together on the earth in peace,"10 and the strong resemblance this has to the Christian vision of the New Creation, it is interesting to note how profoundly Trinitarian this mode of being is. In the turning away from the self to the other, genuine community is found - the antithesis between individuality and sociality is surpassed and synthesized. Julian Young, writes of the later Heidegger's thought in this regard in his The Death of God and the Meaning of Life, ${ }^{11}$ in reference to the festival or "holy-day" which enabled the ancient and medieval cultures to maintain an understanding of the world as more than a mere resource. Young describes the character of Heidegger's mode of being (where Heidegger writes that human beings step into "the full breadth of the space proper to his essence"12 thus:

\footnotetext{
8 Gray, Straw Dogs, 52.

9 Ibid., 46.

10 Gray, Enlightenment's Wake, 229.

11 Julian Young, The Death of God and the Meaning of Life (London: Routledge, 2003).

12 Martin Heidegger, The Question Concerning Technology and Other Essays, trans. W. Lovitt (New York: Harper and Row, 1977), 16.
} 
The wooded hillside...shows up not merely as a store of building material but also as a hillside that is home to the flora and fauna that inhabit it. Second, we step into an intuitive sense of our world as nature's poeisis. We step, that is, out of 'the dull overcastness of the everyday' and into 'the radiance' that comes from an intuitive apprehension of the infinite depth, the boundlessness of Being. And we step, too, into 'the wonder that around us a world worlds, that there is something rather than nothing, that there are things, and that we ourselves are in their midst'. We step, in other words, into an apprehension of our world as something granted to us, something which, rather than being of course there, is something which might not have been, something fragile and precious. As a result, we experience a profound sense of 'gratitude', gratitude for the 'clearing', for illumination, for light, gratitude that there is something rather than nothing. This is what makes the festive state festive - a celebration. $^{13}$

Just as in the Christian vision that Moltmann presents, the world can only be truthfully apprehended as gift, and in that joyful relation of appreciation and care for it.

The consequence of Heidegger's thought is that, far from being the rejection of meaning, a meaning is secured for human being through this mode of being. That meaning, in Heidegger's thought, is having "a fundamental project: to be guardians of our world." ${ }^{14}$ Here is a universal meaning, which can provide a telos toward which human beings may strive. By world, not only nature is intended, but human beings also, as included in that world. Our telos is the fruitful flourishing and care of this world as a unity.

\footnotetext{
13 Young, The Death of God and the Meaning of Life, 207.

14 Ibid., 209.
} 
Heidegger's Gelassenheit is not a nihilistic end of all willing; rather it is a deeper appreciation and knowing of the world; a knowing that reveals the world's true nature as gift, and human beings' own nature as inherently connected to this world, with a vocation to sustain and care for it, enabling it to flourish. The correlation between Heidegger's festive mode of being and the Christian perception of Nature as "creation" and hence a gift, is unmistakable. It is well noted that Heidegger draws his notion of Gelassenheit from Christian mystics; particularly Meister Eckhart. ${ }^{15}$ It appears that Moltmann and Gray, by virtue of his appropriation of Heidegger, are in agreement that the way forward for humankind lies in this approach to the world; in the encountering of the world as it is in itself, rather than as it is useful for human needs and purposes.

Gray's anthropology does not allow for human beings to be defined by anything other than their needs. Consequently, it is unlikely that his anthropology could support such a self-transcending, meditative approach to the world. However, the psychology of Abraham Maslow suggests a possible way forward, and a resolution between Gray's definition of human beings as motivated by animal needs, and a more theological anthropology that suggests that human beings are most themselves when they can transcend themselves through the contemplation of the other. Maslow is best known for his "hierarchy of needs" ${ }^{16}$ that defines human beings as motivated by needs (in agreement with Gray), but that states that when lower needs are met (like

\footnotetext{
15 Gray, Enlightenment's Wake, 273.

16 Abraham Maslow, Motivation and Personality (New York: Harper and Bros., 1954).
} 
the "animal needs", which Gray believes constitute our nature - needs like food, sex, shelter) then higher needs become dominant (such as the need to belong, to have significance and to be loved). In this anthropology, human beings are not one static thing, but have the potential to become "self-actualised". The state of self-actualization is one that few reach, but it represents the highest possibilities of human nature. For those who attain this state, the meditative, self-transcendent knowing of the world and others is characteristic of their state. Maslow writes:

Self-actualising people are, without one single exception, involved in a cause outside their own skin, in something outside of themselves. They are devoted, working at something, something which is very precious to them - some vocation or calling in the old sense, the priestly sense. They are working at something which fate has called them to somehow and which they work at and which they love so that the work-joy dichotomy in them disappears. One devotes his life to the law, another to justice, another to beauty or truth. All, in one way or another, devote their lives to the search for what I have called the "being" values ...the ultimate values which are intrinsic, which cannot be reduced to anything more ultimate... They are the values of being. ${ }^{17}$

In Maslow's anthropology, then human beings are both motivated by their needs, but potentially motivated by "ultimate values". Hence, human nature is not fixed; rather human beings can be a range of higher or lower selves. Gray builds his thought only on the lower potentialities of human nature. For this kind of human being the ultimate values are not present; they cannot

\footnotetext{
17 Abraham Maslow, The Farther Reaches of Human Nature, An Esalen Book (New York: Viking Books, 1971), 42.
} 
comprehend them.

Maslow's self-actualizer's perceive the world in Heidegger's "festive" mode of being, or with Gelassenheit; non-actualizers are purely anthropocentric, displaying the traits that Gray ascribes to modern thinking. Maslow contrasts the two ways of being. The perception of actualizers is as follows: "The object is permitted to be itself. Humble, receptive, passive choiceless, undemanding. Taoistic, non-interference with the object or percept. Let-be acceptance."18 This is Gelassenheit. For the non-actualizers, their perception is thus: "Active shaping, organizing, and selecting by the perceiver. He shifts it, he rearranges it. He works at it...Trying, striving, effort. Will, control." 19 This is the modern attitude, the one that Gray defines humanity by. In this way of perceiving, there are no eternal values, only the willing of the self. Of course, people may be a mixture of these two states at any time, but the point is clear that if there are no universals for Gray, it is because he only recognizes the lower form of human being. The Gelassenheit which he points to as the future for human beings, is not a possible future for Gray's "straw dogs"; human beings defined only by their animal needs. For beings such as these, their existence may well be meaningless.

Maslow's thought also highlights the dialectic between human beings and society - the aforementioned antithesis between individuality and sociality. Gray defines human sociality as an irresolvable conflict between

\footnotetext{
18 Ibid., 251.

19 Ibid.
} 
individuality and sociality. His proposal of a modus vivendi is an attempt to limit the loss to individuals, through the arena of political negotiation. Maslow, however, sees the relationship in more dialectical terms. The relationship between individuals and their society is a mutually transformative one. Individual and society are in a dialectical relationship, such that, as one improves, so does the other. Maslow writes, in regard to the individual and the society (world, in his words):

They happen simultaneously and can be set off on either side, i.e., the more whole the world becomes, the more whole the person becomes. And also, the more whole the person becomes, the more whole becomes the world. It is a dynamic interrelation, a mutual causation.... The communication relationship between the person and the world is a dynamic one of mutual forming and lifting-lowering of each other, a process that we may call "reciprocal isomorphism." A higher order of persons can understand a higher order of knowledge; but also a higher order of environment tends to lift the level of the person, just as a lower order of environment tends to lower it. They make each other like each other. These notions are also applicable to the interrelations between persons, and should help us to understand how persons help to form each other. ${ }^{20}$

Just as human nature is not fixed, so also the potential for human society is not fixed. Rather they are dependent on each other. Again, the Trinitarian nature of human social life is evident - things work not in isolation but in mutual interdependence.

Gray is correct that human beings can have no meaning for their lives, if we define their lives simply as that of "straw dogs" - of beings driven only

20 Ibid., 160-1. 
by their animal needs. Their only meaning can be that of consuming and conflicting with others who seek to consume the same scarce resources. Nihilism and destruction are the end of this being. However, if human beings can also practice Gelassenheit; if they can come to know this world, and their place in it as being of the character of a gift, then joy, and an ever increasing commitment to ultimate values of peace, justice and beauty and above all to the value of love - to the transcending of their individuality through the other then human being has a hopeful future. It is a future where the antithesis and conflict between individual and society are transcended and where all things will be made one; it will be the fulfillment of the vision that Gray projects in Enlightenment's Wake, with "profoundly different forms of human community dwelling together on the earth in peace."21

Finally, Gray makes a significant contribution to modern political discourse in identifying the Enlightenment ideal as violent and as an essentially "religious" impulse, derived from the ubiquitous human need to find meaning in life, and hence to posit a telos, from which we may derive the values that will enable us to achieve this vision of the "the Good, the Beautiful and the True." However, in rejecting all ontological and teleological proposals as erroneous, Gray does not provide himself with an adequate platform on which to ground his modus vivendi. Rather, his thought tends toward nihilism and therefore cannot distinguish between violent or peaceful ways of life as being of any more or less value. Gray describes modern utopian politics as a

21 Gray, Enlightenment's Wake, 229. 
"Black Mass" - a perversion of Christian hopes that ends in violence - and in fact Gray's own proposal, with its vision of peaceful human community is much closer to the vision projected in the authentic Christian Mass. However, it is similarly a parody and a performance of similarly faith-inspired hopes but without an adequate foundation to ground it. Gray's thought is similar to the "Black Mass" that he critiques, but with a more peaceful vision; a "Gray Mass" perhaps. 


\section{BIBLIOGRAPHY}

Bauckham, Richard. God Will Be All in All : The Eschatology of Jürgen Moltmann. 1st ed. Minneapolis: Fortress Press, 2001.

Bentley-Hart, David. Atheist Delusions: The Christian Revolution and lts Fashionable Enemies. New Haven: Yale University Press, 2009.

van den Berg, Floris. "Gray's Anatomy by John Gray | Philosophy Now", n.d. http://www.philosophynow.org/issue76/Grays_Anatomy_by_John_Gray.

Buchanan, James. "The Metamorphosis of John Gray." Constitutional Political Economy 6 (1995): 293-295.

Cavanaugh, William. The Myth of Religious Violence. New York: Oxford University Press, 2009.

Copleston, Frederick. A History of Philosophy. Vol. 1. 9 vols. New York: First Image Books, 1994.

Crowder, George. "Gray and the Politics of Pluralism." In The Political Theory of John Gray, 59-76. London: Routledge, 2007.

- - - . Liberalism and Value Pluralism. New York: Continuum International Publishing Group, 2002.

Derbyshire, Jonathon. "The NS Profile: John Gray." The New Statesman, n.d. http://www.newstatesman.com/philosophy/2009/04/john-gray-enlighten ment-world.

Gordon, David. "The Mises Review: Black Mass." The Mises Review 13, no. 4 (2007).

Gorner, Paul. Twentieth Century German Philosophy. Oxford: Oxford University Press, 2000.

Gray, John. Al Qaeda and What It Means to Be Modern. London: Faber and Faber, 2003.

- - -. "An Illusion with a Future." Daedalus 133, no. 3 (July 1, 2004): 10-17.

- - - Beyond the New Right: Markets, Government, and the Common Environment. London: Routledge, 1993.

- - - Black Mass: Apocalyptic Religion and the Death of Utopia. London: Allen Lane, 2007.

- - - Enlightenment's Wake: Politics and Culture at the Close of the Modern Age. New York: Routledge, 1995.

- - - False Dawn: The Delusions of Global Capitalism. London: Granta, 1998.

- - - . "Global Utopias and Clashing Civilizations: Misunderstanding the Present." International Affairs (Royal Institute of International Affairs 1944-) 74, no. 1 (January 1, 1998): 149-163.

- - - Gray's Anatomy: Selected Writings. London: Penguin Books, 2010. 
- - - . Hayek on Liberty. Oxford [Oxfordshire]: Blackwell, 1984.

- - - . Heresies : Against Progress and Other Illusions. London: Granta, 2004.

- - - . Liberalism. Concepts in the Social Sciences. Milton Keynes: Open University Press, 1986.

- - - Liberalisms: Essays in Political Philosophy. London: Routledge, 1989.

- - - . Mill on Liberty: A Defence. International Library of Philosophy. London: Routledge \& K. Paul, 1983.

- - - "Mill's Liberalism and Liberalism's Posterity." The Journal of Ethics 4, no. 1/2 (March 2000): 137-165.

- - -. "Modus Vivendi: Liberalism for the Coming Ages." New Perspectives Quarterly 18, no. 2 (January 1, 2001): 4-21.

- - - "On Negative and Positive Liberty." Political Studies 28, no. 4 (December 1980): 507-526.

- - - "Pluralism and Toleration in Contemporary Political Philosophy." Political Studies 48, no. 2 (Special Issue 2000 2000): 323.

- - - Post-Liberalism: Studies in Political Thought. New York: Routledge, 1993.

- - - "Reply to Critics." In The Political Theory of John Gray, 262-291. London: Routledge, 2007.

- - - Straw Dogs: Thoughts on Humans and Other Animals. London: Granta, 2002.

- - - Two Faces of Liberalism. Cambridge: Polity Press in association with Blackwell, 2000.

- - -. "Utopian Academics and the Collapse of Communism." Academic Questions 5, no. 1 (March 1992): 66-69.

- - - "Where Pluralists and Liberals Part Company." International Journal of Philosophical Studies 6, no. 1 (March 1998): 17-36.

Gray, John, and Institute of Economic Affairs (Great Britain). Limited Government: A Positive Agenda. Hobart paper 113. London: Institute of Economic Affairs, 1989.

Grayling, A.C. "Through the Looking Glass." The New Humanist, n.d. http://newhumanist.org.uk/1423/through-the-looking-glass.

Green, Toby. "Apocalypse Now and Then." The Independent. London, June 29, 2007.

http://www.independent.co.uk/arts-entertainment/books/reviews/black-m ass-by-john-gray-455059.html.

Griswold, Charles L. "Review: [untitled]." Political Theory 27, no. 2 (April 1, 1999): 274-281.

Harvie, Timothy. Jurgen Moltmann's Ethics of Hope. Surrey: Ashgate, 2009.

Heidegger, Martin. The Question Concerning Technology and Other Essays. 
Translated by W. Lovitt. New York: Harper and Row, 1977.

Horton, John. "John Gray and the Political Theory of Modus Vivendi." In The Political Theory of John Gray, 43-57. London: Routledge, 2007.

Horton, John, and Glen Newey, eds. The Political Theory of John Gray. London: Routledge, 2007.

Ignatieff, Michael. Isaiah Berlin: A Life. New York: Holt Paperbacks, 1999.

J.S. Mill On Liberty in Focus. Routledge philosophers in focus series. London: Routledge, 1991.

"John Gray - The Atheist Delusion." The Guardian. London, March 15, 2008. http://www.investigatingatheism.info/johngray.html.

Johnson, Gregory. "The Non - Sequitur of Value Relativism: A Critique of John Gray's 'Post-Liberalism'.” Reason Papers, no. 19 (Fall 1994): 99-108.

Katznelson, Ira. "A Properly Defended Liberalism: On John Gray and the Filling of Political Life." Social Research 61, no. 3 (Fall 1994): 611-630.

Lassman, Peter. "Pluralism and its Discontents: John Gray's

Counter-Enlightenment." In The Political Theory of John Gray, 99-113. London: Routledge, 2007.

MacIntyre, Alasdair. After Virtue. Third Edition. Notre Dame, Indiana: University of Notre Dame Press, 2007.

- - - Whose Justice? Which Rationality? Notre Dame: University of Notre Dame Press, 2003.

Maslow, Abraham. Motivation and Personality. New York: Harper and Bros., 1954.

--- . Religions, Values, and Peak-Experiences. New York: Penguin Books, 1976.

- - - The Farther Reaches of Human Nature. An Esalen Book. New York: Viking Books, 1971.

McFadyen, Alastair. The Call to Personhood: A Christian Theory of the Individual in Social Relationships. Cambridge: Cambridge University Press, 1990.

McGrath, Alister E. Christian Theology: An Introduction. Blackwell Publishers, 2001.

Mill, John Stuart. On Liberty and Other Essays. World's Classics. Oxford, U.K: Oxford University Press, 1991.

Minogue, Kenneth R, and Centre for Independent Studies (Australia). Ideas About Freedom: A Discussion. CIS occasional papers 15. St. Leonards, N.S.W: Centre for Independent Studies, 1986.

Moltmann, Jürgen. God in Creation: A New Theology of Creation and the Spirit of God. Fortress Press, 1993.

- - - In the End, the Beginning: The Life of Hope. Fortress Press, 2004.

- - - The Church in the Power of the Spirit: A Contribution to Messianic 
Ecclesiology. Fortress Press, 1977.

- - - . The Coming of God: Christian Eschatology. Translated by Margaret Kohl. Augsburg Fortress Pub, 2004.

- - - . The Crucified God: The Cross of Christ as the Foundation and Criticism of Christian Theology. Translated by R. A. Wilson. Fortress Press, 1993.

- - - . The Spirit of Life: A Universal Affirmation. Fortress Press, 2001.

- - - The Trinity and the Kingdom: The Doctrine of God. Fortress Press, 1993.

- - - The Way of Jesus Christ: Christology in Messianic Dimensions. Fortress Press, 1990.

- - - Theology of Hope: On the Ground and the Implications of a Christian Eschatology. Fortress Press, 1993.

Moody-Adams, Michele M. "Review: [untitled]." Victorian Studies 36, no. 2 (January 1, 1993): 247-248.

Morgan, Glyn. "Gray's Elegy for Progress." In The Political Theory of John Gray, 115-129. London: Routledge, 2007.

Newey, Glen. "Gray's Blues: Pessimism as a Political Project." In The Political Theory of John Gray, 151-172. London: Routledge, 2007.

Rengger, Nicholas. "Review Article: The Exorcist? John Gray, Apocalyptic Religion and the Return to Realism in World Politics." International Affairs 83, no. 5 (n.d.): 951-959.

Roberts, Marcus. "The Endurance of History? Reflections on John Gray's Post-Enlightenment Pluralism." Res Publica 3, no. 2 (1997): 185-212.

Rowland, Barbara M. "Review: The Impact of Contemporary Conservatism on Modern Political Thought: A Review Essay." The Western Political Quarterly 41, no. 2 (June 1, 1988): 401-412.

Self, Will. "John Gray: Forget Everything You Know." The Independent. London, September 3, 2003.

http://www.independent.co.uk/news/people/profiles/john-gray-forget-eve rything-you-know-641878.html; Internet.

Smith, George. Policy and Priority. Milton Keynes: Open University Press, 1978.

Taylor, Laurie. "Going Nowhere: Laurie Taylor Interviews John Gray." The New Humanist, n.d. http://newhumanist.org.uk/939.

Ward, lan. "Review: God, Terror and Law." Oxford Journal of Legal Studies 28, no. 4 (December 1, 2008): 783-796.

Wright, N. T. Surprised by Hope: Rethinking Heaven, the Resurrection, and the Mission of the Church. HarperOne, 2008.

- - - The New Testament and the People of God. Vol. 1. Christian Origins and the Question of God. London: SPCK, 1992.

Young, Julian. The Death of God and the Meaning of Life. London: Routledge, 2003. 